\title{
ONREL
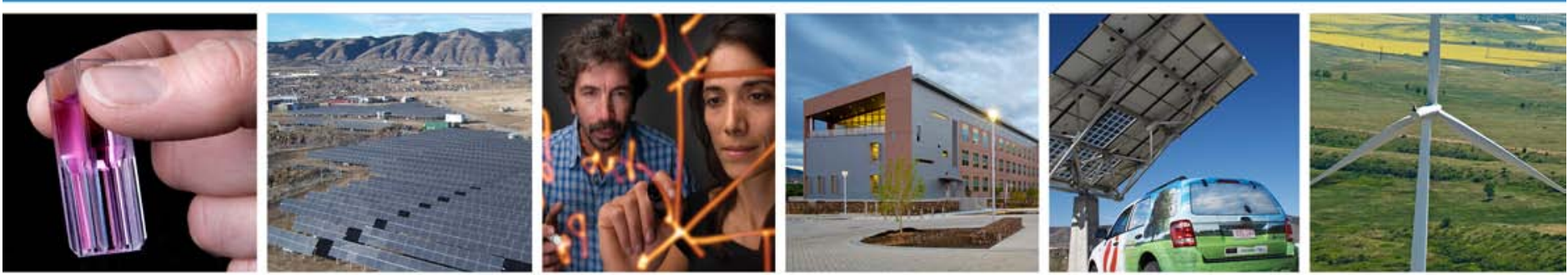

\section{Feasibility Study of Economics and Performance of Solar Photovoltaics in the Commonwealth of Puerto Rico}

\section{A Study Prepared in Partnership with the Environmental Protection Agency for the RE-Powering America's Land Initiative: Siting Renewable Energy on Potentially Contaminated Land and Mine Sites}

James Salasovich and Gail Mosey 


\section{Feasibility Study of Economics and Performance of Solar Photovoltaics in the Commonwealth of Puerto Rico}

\section{A Study Prepared in Partnership with the Environmental Protection Agency for the RE-Powering America's Land Initiative: Siting Renewable Energy on Potentially Contaminated Land and Mine Sites}

James Salasovich and Gail Mosey

Prepared under Task No. WFD6.1000 


\section{NOTICE}

This report was prepared as an account of work sponsored by an agency of the United States government. Neither the United States government nor any agency thereof, nor any of their employees, makes any warranty, express or implied, or assumes any legal liability or responsibility for the accuracy, completeness, or usefulness of any information, apparatus, product, or process disclosed, or represents that its use would not infringe privately owned rights. Reference herein to any specific commercial product, process, or service by trade name, trademark, manufacturer, or otherwise does not necessarily constitute or imply its endorsement, recommendation, or favoring by the United States government or any agency thereof. The views and opinions of authors expressed herein do not necessarily state or reflect those of the United States government or any agency thereof.

Available electronically at http://www.osti.gov/bridge

Available for a processing fee to U.S. Department of Energy and its contractors, in paper, from:

U.S. Department of Energy Office of Scientific and Technical Information P.O. Box 62

Oak Ridge, TN 37831-0062

phone: 865.576 .8401

fax: 865.576 .5728

email: mailto:reports@adonis.osti.gov

Available for sale to the public, in paper, from:

U.S. Department of Commerce National Technical Information Service 5285 Port Royal Road Springfield, VA 22161 phone: 800.553 .6847 fax: 703.605.6900

email: orders@ntis.fedworld.gov online ordering: http://www.ntis.gov/help/ordermethods.aspx

Cover Photos: (left to right) PIX 16416, PIX 17423, PIX 16560, PIX 17613, PIX 17436, PIX 17721

Printed on paper containing at least $50 \%$ wastepaper, including $10 \%$ post consumer waste. 


\section{Acknowledgments}

We would like to thank Anthony Lopez, NREL, for providing GIS analysis and Vince Pitruzzello and Phil Flax, EPA, for assisting with the site visits and facilitating with the Commonwealth of Puerto Rico. We would also like to thank everyone from the Commonwealth for being welcoming hosts. 


\section{Executive Summary}

The U.S. Environmental Protection Agency (EPA), in accordance with the RE-Powering America's Land initiative, selected the Commonwealth of Puerto Rico for a feasibility study of renewables on several sites that are targeted for closure under the Resource Conservation and Recovery Act (RCRA). ${ }^{1}$ The RCRA regulates the disposal of solid and hazardous waste. Citizens of Puerto Rico, city planners, and site managers are interested in redevelopment uses for landfills in Puerto Rico that are particularly well suited for solar photovoltaic (PV) installation. The purpose of this report is to assess the landfills with the highest potential for possible solar PV installation and estimate cost, performance, and site impacts of three different PV options: crystalline silicon (fixed tilt), crystalline silicon (single-axis tracking), and thin film (fixed tilt). Each option represents a standalone system that can be sized to use an entire available site area. In addition, the report outlines financing options that could assist in the implementation of a system. Landfill gas is another possible renewable energy option for the landfills in Puerto Rico. Landfill gas is briefly addressed in this feasibility study, but PV is the main focus.

The feasibility of PV systems installed on landfills is highly impacted by the available area for an array, solar resource, operating status, landfill cap status, distance to transmission lines, and distance to major roads. All of the landfills in Puerto Rico were screened according to these criteria in order to determine the sites with the greatest potential. Eight landfills were chosen for site visits based on the screening criteria and location. Because of time constraints and the fact that Puerto Rico is a relatively large island, the eight landfills chosen for this visit were all located in the same region, the eastern half of the island. The findings from this report can also be applied to landfills in the western half of the island. The following lists the eight landfills in alphabetical order:

1. Cataño

2. Guayama

3. Guaynabo

4. Salinas

5. San Juan

6. Santa Isabel

7. Toa Alta

8. Toa Baja

The electric utility serving Puerto Rico is the Puerto Rico Electric Power Authority (PREPA). According to the most recent annual report ${ }^{2}$ published by PREPA in June 2009, average residential electric rates were $\$ 0.2158 / \mathrm{kWh}$, average commercial rates were $\$ 0.2232 / \mathrm{kWh}$, and average industrial rates were $\$ 0.1831 / \mathrm{kWh}$. These electric rates are similar to those found in the Hawaiian Islands and they are roughly double the average electric rate in the Unites States. The

\footnotetext{
${ }^{1}$ EPA. “RCRA Online.” http://www.epa.gov/epawaste/inforesources/online/index.htm. Accessed January 10, 2011.

${ }^{2}$ Thirty-Sixth Annual Report on the Electricity Property of the Puerto Rico Electric Power Authority. http://www.aeepr.com/INVESTORS/Financial\%20Information/Annual\%20Reports/ConsEng_36th_Rpt_2009\%20A nnual\%20Report\%20Final.pdf. Accessed December 8, 2010.
} 
net-metering laws in Puerto Rico state that whatever the PV electric output above the customer use, PREPA will buy $75 \%$ of that at either the avoided fuel cost or $\$ 0.10 / \mathrm{kWh}$, whichever is greater. The avoided fuel cost is in the range of $\$ 0.10 / \mathrm{kWh}$ or lower, so $\$ 0.10 / \mathrm{kWh}$ was assumed. The PV system size limit for net metering is $25 \mathrm{~kW}$ for residential and $1 \mathrm{MW}$ for commercial.

There is little to no electricity use at a closed landfill and all of the electricity generated by a proposed PV system is assumed to be sold back to the utility. From an economic standpoint, the current net-metering laws in Puerto Rico are not advantageous for PV systems that generate large amounts of excess energy because of the relatively low buyback rate of $75 \%$ of $\$ 0.10 / \mathrm{kWh}$. Setting up a power purchase agreement (PPA) where PREPA would agree to buy back the power at a higher rate would be much more beneficial. There are currently two large-scale PV projects in Puerto Rico that were both started in 2010 that use a PPA. The first project ${ }^{3}$ is a $20 \mathrm{MW} \mathrm{PV}$ system in Guayama where AES Ilumina entered a PPA with PREPA; PREPA agreed to buy the electricity at a rate of $\$ 0.13 / \mathrm{kWh}$. The second project ${ }^{4}$ is a $63 \mathrm{MW} \mathrm{PV} \mathrm{system} \mathrm{in} \mathrm{Salinas} \mathrm{where}$ the CIRO One Group entered a PPA with PREPA, but the buyback rate has yet to be established.

The economics of the potential systems were analyzed assuming that a PPA with PREPA would be used and PREPA would buy back the electric rate of $\$ 0.13 / \mathrm{kWh}$. Incentives offered by the federal government, the Commonwealth of Puerto Rico, and by PREPA were assumed in this analysis. The federal tax credit is currently $30 \%$. State incentives are currently offered for commercial solar power systems in Puerto Rico for \$4/DC-Watt for up to 50\% of the project costs or $\$ 100,000$, whichever is lower. State incentives of $\$ 8 / \mathrm{DC}-$ Watt for up to $\$ 100,000$ are offered for governmental systems. State incentives of $\$ 4 / \mathrm{DC}-$ Watt for up to $\$ 15,000$ are offered for residential systems. PREPA currently offers no incentives for PV systems. Not all sites need to be developed; beginning with a smaller demonstration system and increasing capacity as funds become available may be a better approach. The economics of a potential PV system on landfills in Puerto Rico depend greatly on the buyback electric rate. Currently, PREPA has entered into PPAs with a buyback rate of $\$ 0.13 / \mathrm{kWh}$. Based on past electric rate increases in Puerto Rico and other islands in the Caribbean, this buyback rate could increase to $\$ 0.15 / \mathrm{kWh}$ or higher in a relatively short amount of time.

\footnotetext{
${ }^{3}$ All Business. "Solar Power Project.” http://www.allbusiness.com/energy-utilities/utilities-industry-electric-powerpower/14753424-1.html. Accessed December 8, 2010.

${ }^{4}$ Marino, J. "Work to Start on 63 MW Solar Plant in Salinas." Caribbean Business. http://www.caribbeanbusinesspr.com/news03.php?nt_id=49337\&ct_id=1. Accessed December 8, 2010.
} 


\section{Table of Contents}

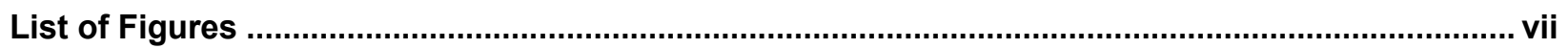

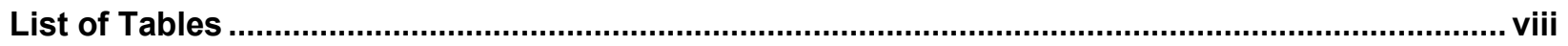

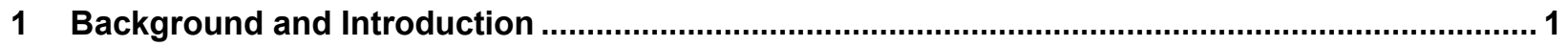

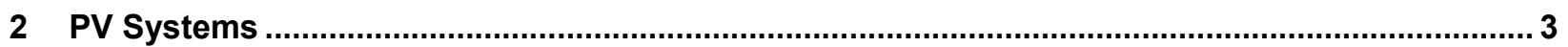

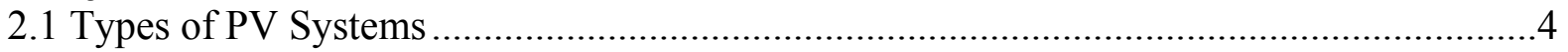

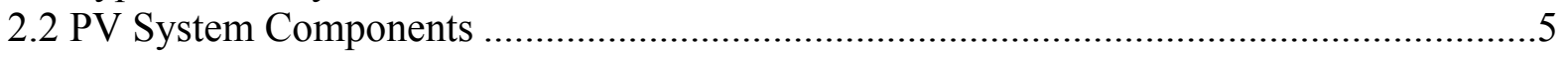

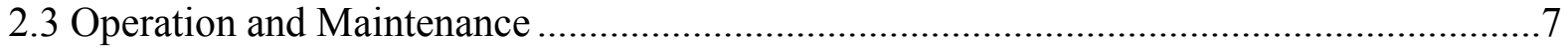

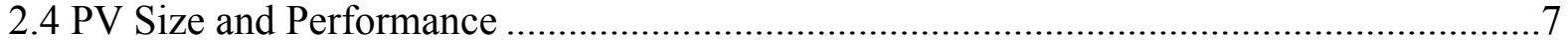

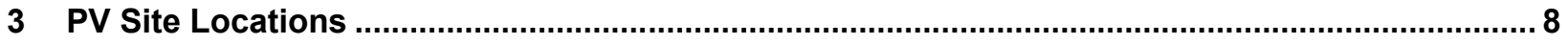

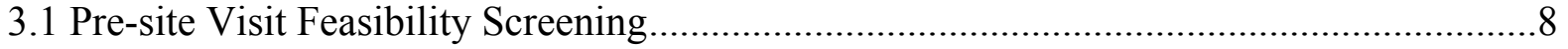

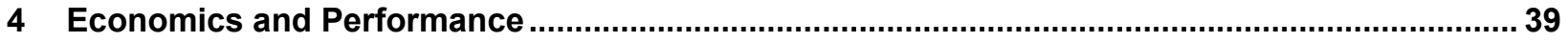

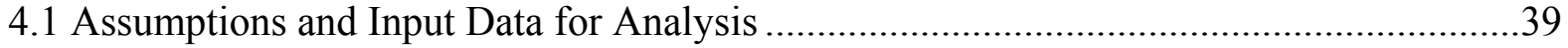

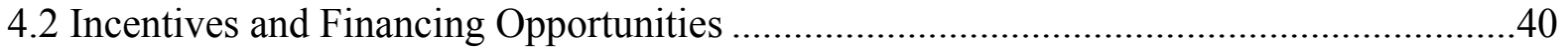

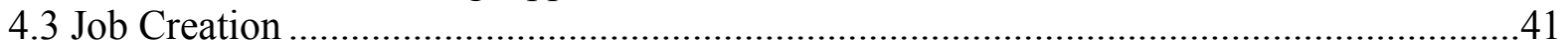

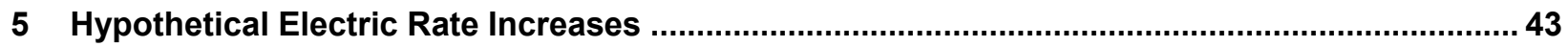

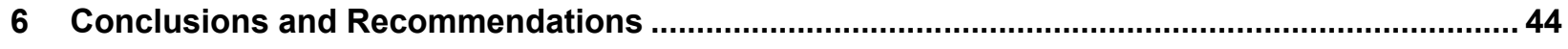

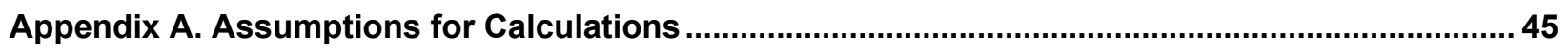

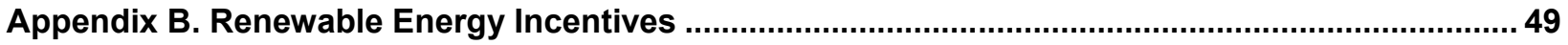




\section{List of Figures}

Figure 1. Major components of grid-connected PV system ................................................. 3

Figure 2. All landfills with roads and transmission lines .............................................. 8

Figure 3. Solar resource availability and landfills in Puerto Rico........................................ 9

Figure 4. High potential landfill sites for solar PV in Puerto Rico ..................................... 10

Figure 5. Views of the feasible area for PV at the Cataño Landfill ...................................... 12

Figure 6. Views of the exposed impermeable plastic liner of the Cataño Landfill cap ............ 13

Figure 7. View of two of the trees that need to be removed at the Cataño Landfill .................. 13

Figure 8. Aerial view of the feasible area for PV at the Cataño Landfill................................ 14

Figure 9. Views of the feasible area for PV at the Guayama Landfill ................................. 16

Figure 10. Aerial view of the feasible area for PV at the Guayama Landfill.......................... 17

Figure 11. Views of the feasible area for PV at the Guaynabo Landfill ................................. 19

Figure 12. Views of the Guaynabo Landfill showing the hilly terrain................................... 20

Figure 13. Guaynabo Landfill recycling center.................................................................... 20

Figure 14. Aerial view of the feasible area for PV at the Guaynabo Landfill and recycling

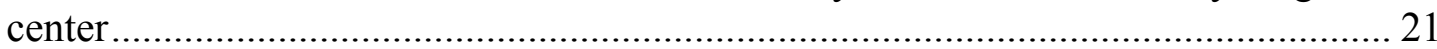

Figure 15. Views of the Salinas Landfill showing the hilly terrain ........................................ 23

Figure 16. Aerial view of the Salinas Landfill with no feasible area for PV ........................... 24

Figure 17. $360^{\circ}$ view of the feasible area for PV at the San Juan Landfill .............................. 25

Figure 18. Golf driving range at the San Juan Landfill .......................................................... 25

Figure 19. Aerial view of the feasible area for PV at the San Juan Landfill............................ 26

Figure 20. San Juan Landfill gas flaring facility ................................................................ 27

Figure 21. Views of the feasible area for PV at the Santa Isabel Landfill .............................. 28

Figure 22. Aerial view of the feasible area for PV at the Santa Isabel Landfill......................... 29

Figure 23. Views of the feasible area for PV at the Toa Alta Landfill ..................................... 31

Figure 24. Aerial view of the feasible area for PV at the Toa Alta Landfill ............................. 32

Figure 25. Views of the feasible area for PV at the Toa Baja Landfill ..................................... 34

Figure 26. Aerial view of the feasible area for PV at the Toa Baja Landfill ............................. 35

Figure 27. Comparison of the feasible areas for PV at landfills in Puerto Rico ....................... 37 


\section{List of Tables}

Table 1. Energy Density by Panel and System for Ground-mounted PV .............................. 4

Table 2. Energy Density by Panel Type for Roof-mounted PV ........................................... 5

Table 3. Cataño Landfill Site PV System Options........................................................... 15

Table 4. Guayama Landfill Site PV System Options........................................................ 18

Table 5. Guaynabo Landfill Site Ground-mounted PV System Options ................................ 22

Table 6. Guaynabo Recycling Center Roof-mounted PV System Options ............................ 22

Table 7. San Juan Landfill Site PV System Options ......................................................... 27

Table 8. Santa Isabel Landfill Site PV System Options ...................................................... 30

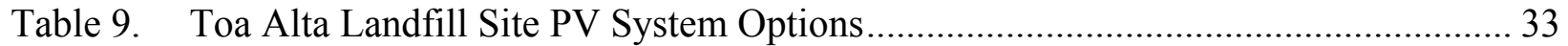

Table 10. Toa Baja Landfill Site PV System Options ....................................................... 36

Table 11. PV System Performance and Economics by System Type.................................... 38

Table 12. Estimated Job Creation by PV System Type Assuming Lower Installed Costs........ 42

Table 13. Estimated Job Creation by PV System Type Assuming Higher Installed Costs ........ 42

Table 14. PV System Performance and Economics Assuming Lower Installed Costs and with a Hypothetical Rate Increase to $\$ 0.15 / \mathrm{kWh}$................................................ 43

Table 15. PV System Performance and Economics Assuming Higher Installed Costs and

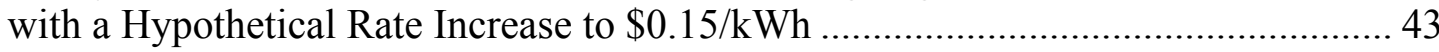

Table A-1. Assumptions for Calculations for Ground-mounted PV Systems Assuming \$3.50/W for Crystalline Silicon Fixed-tilt Systems, \$5.00/W for Single-axis Tracking Systems, and $\$ 3.20 / \mathrm{W}$ for Thin-film Fixed-tilt Systems .................................................. 45

Table A-2. Assumptions for Calculations for Roof-mounted PV Systems Assuming \$6.00/W for Crystalline Silicon and \$5.40/W for Thin-film Systems ...................................... 46

Table A-3. Assumptions for Calculations for Ground-mounted PV Systems Assuming \$7.00/W for Crystalline Silicon Fixed-tilt Systems, \$10.00/W for Single-axis Tracking Systems, and \$6.40/W for Thin-film Fixed-tilt Systems ....................................... 46

Table A-4. Assumptions for Calculations for Roof-mounted PV Systems Assuming \$9.33/W for Crystalline Silicon and \$8.73/W for Thin-film Systems ...................................... 47

Table A-5. Other Assumptions, Including Assumptions for Costs and System Types ............... 48

Table B-1. Redevelopment and Renewable Energy Incentives and Financing Tools ................. 49

Table B-2. Renewable Energy Development Incentives and Financing Tools Applicable to PV 50

Table B-3. State Rebates for Commercial-sector PV Projects............................................... 51

Table B-4. State Tax Credits for Commercial-sector PV Projects ........................................... 55

Table B-5. U.S. Department of Energy Brightfields Program Grants ...................................... 61

Table B-6. State Policy and Incentive Comparisons: Massachusetts, North Carolina, and Colorado.

Table B-7. Key Policy Comparison for Subject States 


\section{Background and Introduction}

The Commonwealth of Puerto Rico is an island located in the northeastern Caribbean Sea and, as of 2010, has a population of approximately 4 million people. The area of Puerto Rico is 3,515 square miles, and the approximate dimensions are 100 miles east to west and 35 miles north to south. The climate is a tropical marine climate with very little temperature variation throughout the year. The main utility company is the Puerto Rico Electric Power Authority (PREPA).

The U.S. Environmental Protection Agency (EPA), in accordance with the RE-Powering America's Land initiative, selected Puerto Rico for a feasibility study of solar photovoltaic (PV) feasibility on several landfill sites. Puerto Rico is particularly well suited for solar PV installation because of the solar resource availability. Due to the presence of suspected or known contaminants, landfills have limited redevelopment potential and solar PV installations are a viable reuse. The purpose of this report is to present the results of a feasibility study conducted by the National Renewable Energy Laboratory (NREL) to assess several landfill sites in Puerto Rico with the highest potential for possible solar PV installation and estimate cost, performance, and site impacts of three different PV options: crystalline silicon (fixed tilt), crystalline silicon (single-axis tracking), and thin film (fixed tilt). Each option represents a standalone system that can be sized to use an entire available site area. In addition, the report outlines financing options that could assist in the implementation of a system.

One very promising and innovative use of closed landfills is to install solar photovoltaic (PV) systems. PV systems can be ground-mounted, and these types of systems work well on landfill sites where there are commonly large unshaded areas. In some cases, PV can be used to form the cap of the landfill. PV may generate revenue on a landfill site that may otherwise go unused. A majority of the landfills in Puerto Rico are municipally owned and operated, and these municipalities are interested in potential revenue flows from PV systems on landfills. PV systems on landfills may give the municipalities a reason to close the landfills in a timely manner and to maintain the landfill cap once it is in place.

The focus of this report is on PV systems, but another use of closed landfills is to install a landfill gas plant. The landfill gas could be used in a heating application or used to operate a generator in order to make electricity. The key points that need to be investigated to determine whether landfill gas capture is feasible are the age of the landfill, the size, and the types of gases generated by the landfill. For landfill gas capture, it is best to have a newly capped landfill because the landfill gas production greatly declines after 20-30 years. The types of gases that are generated by the landfill can be determined by doing a sample test. This involves drilling a hole into the landfill, putting a vacuum on the landfill, and sampling the rate and types of gases being generated. A detailed landfill gas study should be done in order to determine the feasibility of landfill gas capture and use at all relatively newly capped larger landfills in Puerto Rico.

Like most islands, Puerto Rico relies heavily on foreign sources of petroleum to operate its power plants. There are many compelling reasons to consider moving toward renewable energy sources for power generation instead of fossil fuels, including:

- Using oil to produce power may not be sustainable. 
- Burning fossil fuels can have negative effects on human health and the environment.

- Extracting and transporting oil can lead to accidental spills, which can be devastating to the environment and communities.

- Depending on foreign oil can be a threat to national security.

- High and increasing electric rates are associated with oil-based power plants.

- Fluctuating electric costs are associated with oil-based power plants.

- Burning fossil fuels may contribute to climate change. Being an island, Puerto Rico is even more sensitive to climate change and the associated rising sea levels and increased frequency and severity of hurricanes.

- Generating energy without harmful emissions or waste products can be accomplished through renewable energy sources.

- Abundant renewable resources are available in Puerto Rico. 


\section{PV Systems}

Solar photovoltaics (PV) are semiconductor devices that convert sunlight directly into electricity. They do so without any moving parts and without generating any noise or pollution. They must be mounted in an unshaded location; rooftops, carports, and ground-mounted arrays are common mounting locations. PV systems work very well in Puerto Rico, where the average global horizontal annual solar resource is $5.5 \mathrm{kWh} / \mathrm{m}^{2} /$ day. This number, however, is not the amount of energy that can be produced by a PV panel. The amount of energy produced by a panel depends on several factors. These factors include the type of collector, the tilt and azimuth of the collector, the temperature, the level of sunlight, and weather conditions. An inverter is required to convert the direct current (DC) to alternating current (AC) of the desired voltage compatible with building and utility power systems. The balance of the system consists of conductors/conduit, switches, disconnects, and fuses. Grid-connected PV systems feed power into the facility's electrical system and do not include batteries.

Figure 1 shows the major components of a grid-connected PV system and illustrates how these components are interconnected.

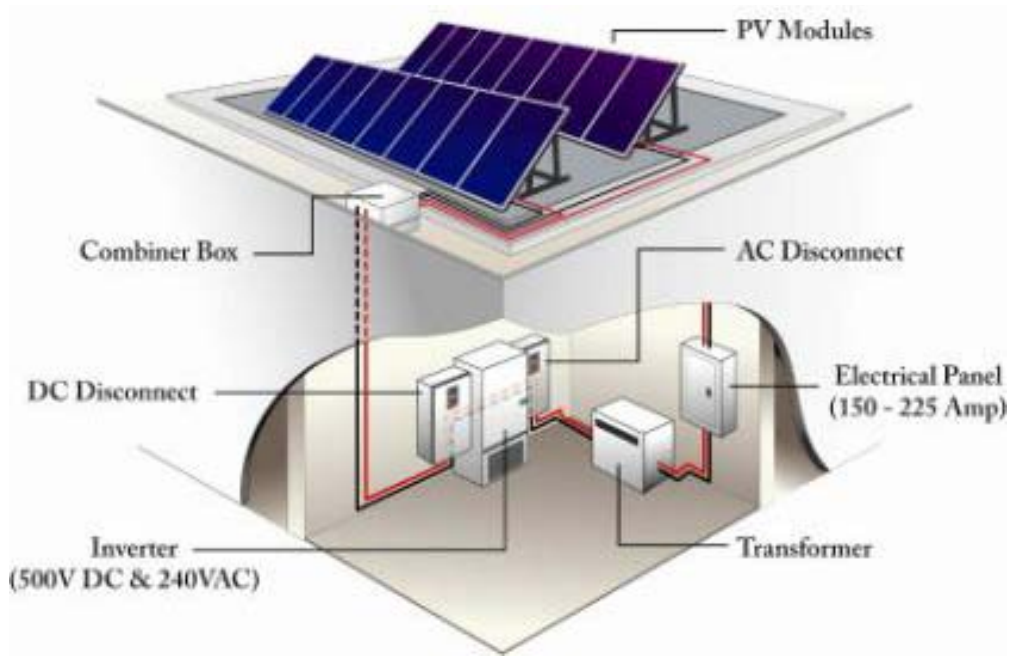

Figure 1. Major components of grid-connected PV system

Credit: NREL

PV panels are made up of many individual cells that all produce a small amount of current and voltage. These individual cells are connected in series to produce a larger current. PV panels are very sensitive to shading. When shade falls on a panel, the shaded portion of the panel cannot collect the high-energy beam radiation from the sun. If an individual cell is shaded, it will act as a resistance to the whole series circuit, impeding current flow and dissipating power rather than producing it. By determining solar access - the unimpeded ability of sunlight to reach a solar collector-one can determine whether an area is appropriate for solar panels.

For this assessment, the National Renewable Energy Laboratory (NREL) team used a solar path calculator to assess shading at particular locations by analyzing the sky view where the solar panels will be located. The solar path calculator is equipped with a fisheye lens that takes a $360^{\circ}$ photo of the sky and plots out the shading obstructions throughout the year on a spherical axis. 
Shading analysis is typically done at locations where shading will most likely be an issue (e.g., close to a stand of trees or a hill on the perimeter of a landfill).

If a site is found to have good solar access for a PV system, then the next step is to determine the size of that system, which highly depends on the average energy use of the on-site facilities. Providing more power than a site would use is dependent on the economics of most net-metering agreements. In the case of the assessed sites, all of the electricity generated at the site would be sold to the serving utility, PREPA, because there is little or no electrical load. The system size would thus be determined by the amount of electricity the electric company would be willing to purchase or by how much land area is available. For the purpose of this report, the NREL assessment team assumed PREPA would purchase any electricity that the site can generate. The systems will be broken down by site so the system size can be adjusted based on what the utility requests.

\subsection{Types of PV Systems}

\subsubsection{Ground-mounted Systems}

On a \$/DC-Watt basis, ground-mounted PV systems are usually the lowest cost option to install. Several PV panel and mounting options are available, each having different benefits for different ground conditions. Table 1 outlines the energy density values that can be expected from each type of system.

Table 1. Energy Density by Panel and System for Ground-mounted PV

\begin{tabular}{lcc}
\hline System Type & $\begin{array}{l}\text { Fixed-tilt Energy Density } \\
\text { (DC-Watts/ft }{ }^{2} \text { ) }\end{array}$ & $\begin{array}{l}\text { Single-axis Tracking } \\
\text { Energy Density } \\
\text { (DC-Watts/ft }\end{array}$ \\
\cline { 2 - 3 } Crystalline Silicon & 4.0 & 3.3 \\
Thin Film & 1.7 & 1.4 \\
Hybrid HE $^{\mathrm{a}}$ & 4.8 & 3.9 \\
\hline${ }^{a}$ Because hybrid high efficiency (HE) panels do not represent a significant portion of \\
the commercial market, they were not included in the analysis. Installing panel types \\
that do not hold a significant portion of the commercial market would not be feasible for \\
a large-scale solar generation plant.
\end{tabular}

For the purpose of this analysis, all fixed-tilt systems were assumed to be mounted at latitude with a tilt of 18.4 degrees. To get the most out of the available ground area, considering whether a site layout can be improved to better incorporate a solar energy system is important. If unused structures, fences, or electrical poles can be removed, the unshaded area can be increased to incorporate more PV panels. When considering a ground-mounted system, an electrical tie-in location should be identified to determine how the energy would be fed back into the grid. For this report, only fixed-tilt ground-mounted systems and single-axis tracking systems were considered.

Fixed-tilt systems are installed at a specified tilt and are fixed at that tilt for the life of the system. Single-axis tracking systems have a fixed tilt on one axis and a variable tilt on the other axis; the system is designed to follow the sun in its path through the sky. This allows the solar radiation to strike the panel at an optimum angle for a larger part of the day than can be achieved with a fixed-tilt system. A single-axis tracking system can collect nearly $30 \%$ more electricity per 
capacity than can a fixed-tilt system. The drawbacks include increased operation and maintenance $(\mathrm{O} \& \mathrm{M})$ costs, less capacity per unit area (DC-Watt $\left./ \mathrm{ft}^{2}\right)$, and greater installed cost (\$/DC-Watt).

\subsubsection{Roof-mounted Systems}

In many cases, a roof is the best location for a PV system. Roof-mounted PV systems are usually more expensive than ground-mounted systems, but a roof is a convenient location because it is out of the way and usually unshaded. Large areas with minimal rooftop equipment are preferred, but equipment can sometimes be worked around if necessary. If a building has a sloped roof, a typical flush-mounted crystalline silicon panel can achieve power densities on the order of $10 \mathrm{DC}-\mathrm{Watt} / \mathrm{ft}^{2}$. For buildings with flat roofs, rack-mounted systems can achieve power densities on the order of $8 \mathrm{DC}-\mathrm{Watt} / \mathrm{ft}^{2}$ with a crystalline silicon panel. Table 2 lists the energy density by panel type for roof-mounted PV.

Table 2. Energy Density by Panel Type for Roof-mounted PV

\begin{tabular}{lc}
\hline System Type & $\begin{array}{l}\text { Fixed-tilt Energy Density } \\
\text { (DC-Watts/ft }{ }^{2} \text { ) }\end{array}$ \\
\cline { 2 - 2 } Crystalline Silicon & 10.0 \\
Thin Film & 4.3 \\
\hline
\end{tabular}

Typically, PV systems are installed on roofs that either are less than 5 years old or have over 30 years left before replacement. The only roof area analyzed was the Recycling Center at the Guaynabo Landfill.

\subsection{PV System Components}

The PV system considered here has these components:

- PV arrays, which convert light energy to DC electricity

- Inverters, which convert DC to AC and provide important safety, monitoring, and control functions

- Various wiring, mounting hardware, and combiner boxes

- Monitoring equipment.

\subsubsection{PV Array}

The primary component of a PV system, the PV array, converts sunlight to electrical energy; all other components simply condition or control energy use. Most PV arrays consist of interconnected PV modules that range in size from 50 peak DC-Watts to 300 peak DC-Watts. Peak watts are the rated output of PV modules at standard operating conditions of $25^{\circ} \mathrm{C}\left(77^{\circ} \mathrm{F}\right)$ and insolation of $1,000 \mathrm{~W} / \mathrm{m}^{2}$. Because these standard operating conditions are nearly ideal, the actual output will be less under typical environmental conditions. PV modules are the most reliable components in any PV system. They have been engineered to withstand extreme 
temperatures, severe winds, and impacts. ASTM E1038- $05^{5}$ subjects modules to impacts from one-inch hail balls at terminal velocity $(55 \mathrm{mph})$ at various parts of the module. PV modules have a life expectancy of 20-30 years, and manufacturers warranty them against power degradation for 25 years. The array is usually the most expensive component of a PV system; it accounts for approximately two-thirds the cost of a grid-connected system. Many PV manufacturers are available. ${ }^{6}$

\subsubsection{Inverters}

PV arrays provide DC power at a voltage that depends on the configuration of the array. This power is converted to $\mathrm{AC}$ at the required voltage and number of phases by the inverter. Inverters enable the operation of commonly used equipment such as appliances, computers, office equipment, and motors. Current inverter technology provides true sine wave power at a quality often better than that of the serving utility. The locations of both the inverter and the balance-ofsystem equipment are important. Inverters are available that include most or all of the control systems required for operation, including some metering and data-logging capability. Inverters must provide several operational and safety functions for interconnection with the utility system. The Institute of Electrical and Electronic Engineers, Inc. (IEEE) maintains standard "P929 Recommended Practice for Utility Interface of Photovoltaic (PV) Systems, "7 which allows manufacturers to write "Utility-Interactive" on the listing label if an inverter meets the requirements of frequency and voltage limits, power quality, and non-islanding inverter testing. Underwriters Laboratory maintains "UL Standard 1741, Standard for Static Inverters and Charge Controllers for Use in Photovoltaic Power Systems, " 8 which incorporates the testing required by IEEE 929 and includes design (type) testing and production testing. A large choice of inverter manufacturers is available. ${ }^{9}$

\footnotetext{
${ }^{5}$ ASTM Standard E1038. "Standard Test Method for Determining Resistance of Photovoltaic Modules to Hail by Impact with Propelled Ice Balls." West Conshohocken, PA: ASTM International, 2005, DOI: 10.1520/E1038-05. http://www.astm.org/Standards/E1038.htm. Accessed September 2010.

${ }^{6}$ Go Solar California, a joint effort of the California Energy Commission and the California Public Utilities Commission, provides consumer information for solar energy systems. See http://www.gosolarcalifornia.org/equipment/pv modules.php. Accessed March 2011.

7 “ANSI/IEEE Std 929-1988 IEEE Recommended Practice for Utility Interface of Residential and Intermediate Photovoltaic (PV) Systems.” http://standards.ieee.org/reading/ieee/std public/description/powergen/9291988 desc.html. Accessed September 2010.

8 "Inverters, Converters, Controllers and Interconnection System Equipment for Use With Distributed Energy Resources: UL 1741." http://ulstandardsinfonet.ul.com/scopes/1741.html. Accessed September 2010.

${ }^{9}$ Go Solar California approves inverters.
} 


\subsection{Operation and Maintenance}

The PV panels come with a 25-year performance warranty. The inverters, which come standard with a 5- or 10-year warranty (extended warranties available), would be expected to last 10-15 years. System performance should be verified on a vendor-provided website. Wire and rack connections should be checked. For this economic analysis, an annual O\&M cost of $0.17 \%$ of total installed cost is used based on O\&M costs of other fixed-tilt grid-tied PV systems. For the case of single-axis tracking, an annual O\&M cost of $0.35 \%$ of the total installed cost is used based on O\&M costs of existing single-axis tracking systems.

\subsection{PV Size and Performance}

PV arrays must be installed in unshaded locations on the ground or on building roofs that have an expected life of at least 25 years. The predicted array performance was found using a combination of PVWATTS, a performance calculator for grid-connected PV systems created by NREL's Renewable Resource Data Center, ${ }^{10}$ and SolOpt, a solar performance tool currently being developed at NREL. The performance data was used to calculate the amount of revenue that could be expected each year. The project economics were based on this analysis, and the calculations can be found in Appendix A.

${ }^{10}$ NREL. "PVWatts." http://www.nrel.gov/rredc/pvwatts/. Accessed September 2010. 


\section{PV Site Locations}

This section summarizes the findings of the NREL solar assessment site visit on March 23-24, 2010 .

\subsection{Pre-site Visit Feasibility Screening}

Puerto Rico has over 30 landfills throughout the island; see Figure 2 for a representation of the landfills plus roads and transmission lines. Some of these landfills are better suited to solar PV system placement than others. To narrow down the list of landfills and identify those sites with the most potential for solar PV systems, screening criteria was applied to each of the landfills.

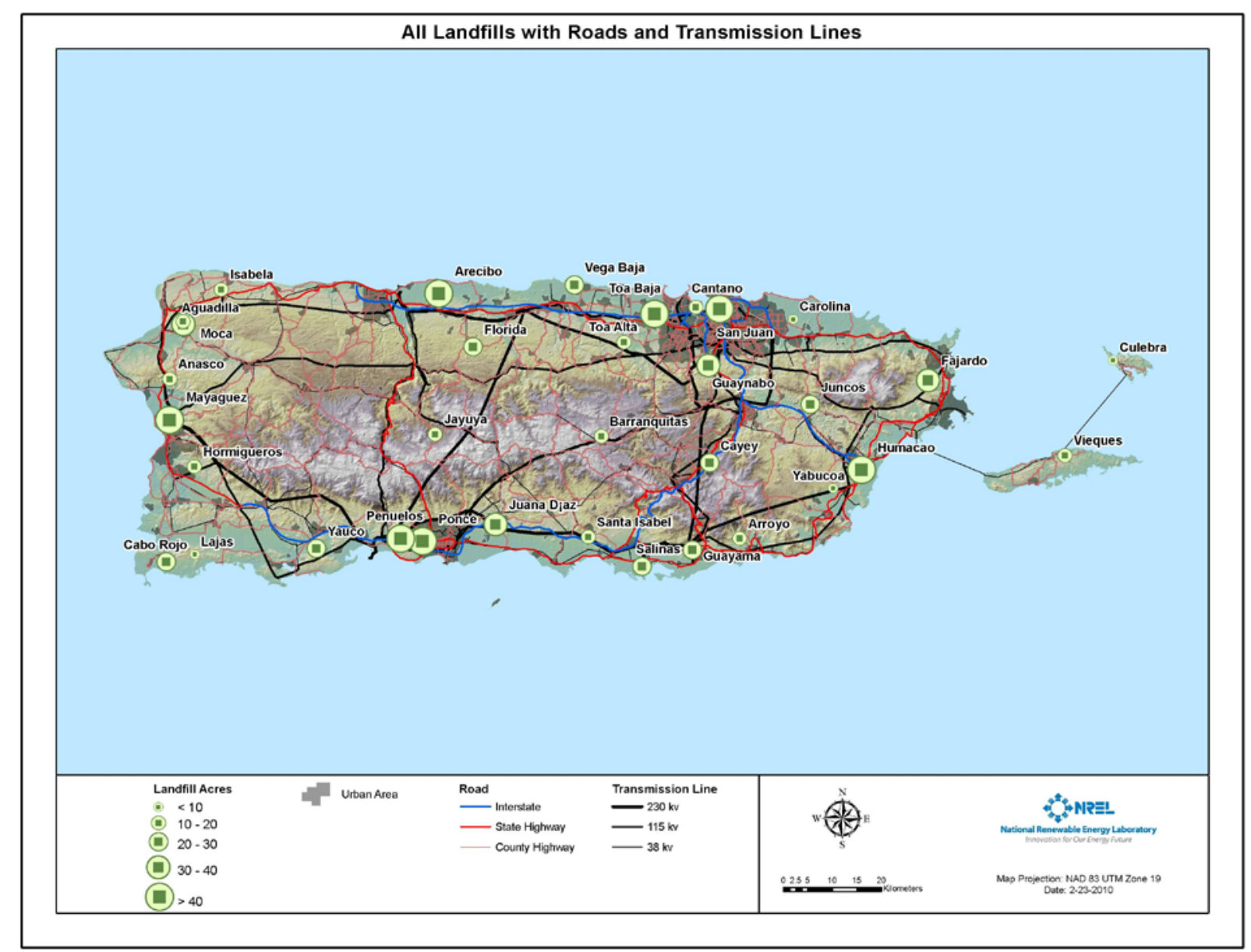

Figure 2. All landfills with roads and transmission lines

Credit: Anthony Lopez, NREL

The screening criteria consider aspects of the site that make it amenable to solar PV system placement and also consider infrastructure around the site, such as distance to roads and transmission lines, which make the system more feasible and economical. The screening criteria are as follows:

- Solar resource availability 
- Acreage of the site

- Distance to graded road

- Distance to transmission lines

- Slope of the site.

All of the landfills in Puerto Rico have adequate solar resource availability for a solar PV system; see Figure 3 for a representation of the solar resource in Puerto Rico super-imposed on the landfill locations.

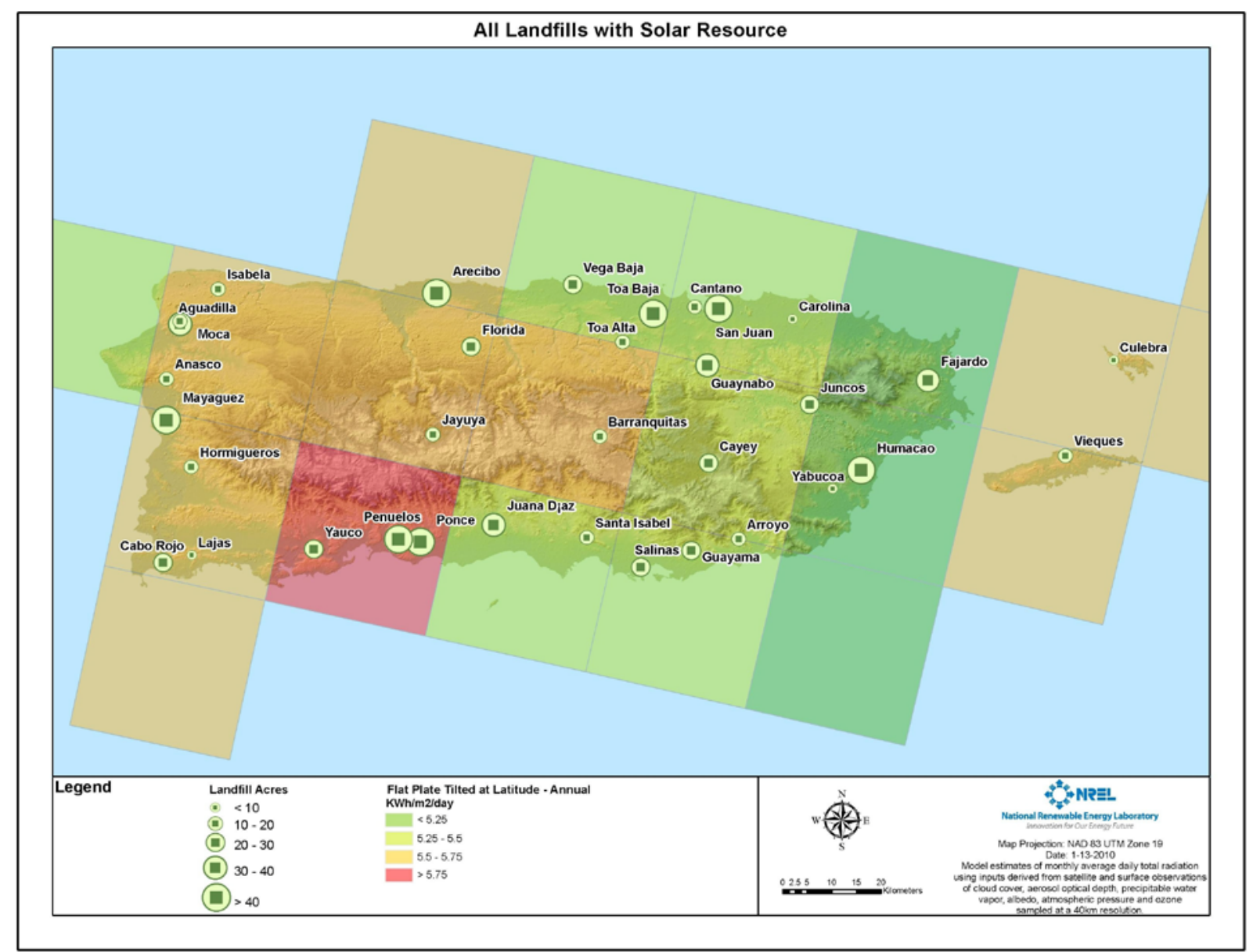

Figure 3. Solar resource availability and landfills in Puerto Rico

Credit: Anthony Lopez, NREL

The minimum acreage for a site to be considered high potential is 14 acres. This is an adequate size for a solar PV system to be feasible ${ }^{11}$ and is reasonably inclusive of the landfills in Puerto Rico. Maximum distance to a graded road for solar PV is a loose criterion because PV systems

${ }^{11}$ As a rule of thumb, NREL assumes $65 \mathrm{~W} / \mathrm{m}^{2}$ or $263 \mathrm{~kW} /$ acre for ground-mounted fixed tilt, $48 \mathrm{~W} / \mathrm{m}^{2}$ or 194 $\mathrm{kW} /$ acre for single-axis tracking, and $20 \mathrm{~W} / \mathrm{m}^{2}$ or $81 \mathrm{~kW} /$ acre for two-axis tracking. Denholm, P.; Margolis, R.M. (2008). "Land Use Requirements and the Per-Capita Solar Footprint for Photovoltaic Generation in the United States." Energy Policy (36); pp. 3531-3543. 
can be transported on secondary roads, and most landfills in Puerto Rico have reasonable road access due to the nature of the former or ongoing landfill operation. Distance to transmission is another matter because of the expense associated with installing adequate transmission lines. Most, but not all, of the landfills in Puerto Rico are close to transmission of $38 \mathrm{kV}$, so a maximum distance of 1 mile to transmission was applied. The slope of the site should be no greater than $20 \%$ to allow for successful installation of the PV system. After applying the above criteria, 16 landfills were deemed as very high potential sites for solar PV, as seen in Figure 4.

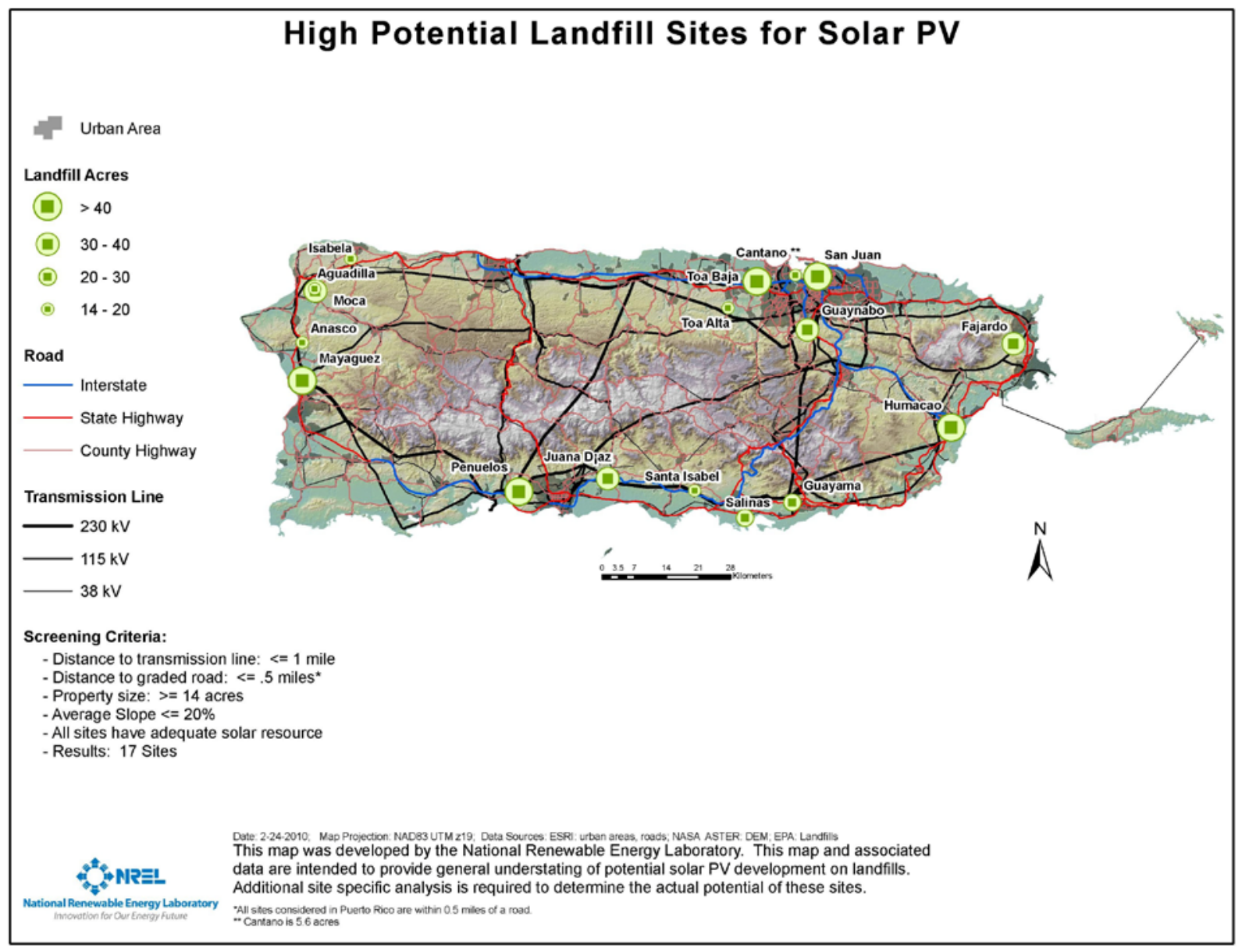

Figure 4. High potential landfill sites for solar PV in Puerto Rico

Credit: Anthony Lopez, NREL

Once the landfills with the highest potential for PV were determined, a plan for a site visit could be mapped out. Because of time constraints and the fact that Puerto Rico is a relatively large island, it was determined that only 5-10 landfills could be assessed during the scheduled 2-day site visit. Furthermore, the 5-10 landfills would have to be located in generally the same region of the island. At the start of the site visit, the high potential sites were reviewed, and eight landfill sites for solar PV were chosen for site visits, as listed below in alphabetical order. Both the Cataño and San Juan Landfills were added to the site visit list after arriving in Puerto Rico and clarifying with site personnel the suitability of the sites. 
1. Cataño

2. Guayama

3. Guaynabo

4. Salinas

5. San Juan

6. Santa Isabel

7. Toa Alta

8. Toa Baja

The eight landfills visited are all located in the eastern half of the island. The method for screening the sites and the findings from this report can generally be applied to other landfills throughout the island that were not visited due to similar climate and environmental conditions. The following sections summarize the findings of the NREL solar assessment.

There are currently two large-scale PV projects in Puerto Rico that were both started in 2010 that use a PPA. The first project $^{12}$ is a $20 \mathrm{MW}$ PV system in Guayama where AES Ilumina entered a PPA with PREPA; PREPA agreed to buy the electricity at a rate of $\$ 0.13 / \mathrm{kWh}$. The second project $^{13}$ is a $63 \mathrm{MW}$ PV system in Salinas where the CIRO One Group entered a PPA with PREPA, but the buyback rate has yet to be established. The economics of the potential systems were analyzed assuming that a power purchase agreement (PPA) with PREPA would be used and PREPA would buy back the electricity at an electric rate of $\$ 0.13 / \mathrm{kWh}$. Incentives offered by the federal government, the Commonwealth of Puerto Rico, and by PREPA were assumed in this analysis ${ }^{14}$.

The cost of PV systems in Puerto Rico varies and therefore two cost estimates were used. The first estimate is in the low range of current installed costs of PV systems and is based on costs of the $20 \mathrm{MW}$ system that is currently being installed in Guayama by AES Ilumina. The second estimate is in the higher range of current installed costs of PV systems and is based on past costs of smaller scale systems. Further discussion regarding assumptions and input data for analysis can be found in Section 4 of the report.

\subsubsection{Cataño Landfill PV System}

Cataño is located on the north shore of Puerto Rico and is adjacent to the city of San Juan, which is to the east. The approximate population is currently 30,000. The Cataño Landfill is located to the southwest of Cataño and is to the west of highway PR-165. It is approximately 3 miles southwest of San Juan. The Cataño Landfill is not a highly visible site as it is surrounded by trees. Figure 5 shows various views of the Cataño Landfill.

\footnotetext{
${ }^{12}$ All Business. "Solar Power Project.” http://www.allbusiness.com/energy-utilities/utilities-industry-electric-powerpower/14753424-1.html. Accessed December 8, 2010.

${ }_{13}$ Marino, J. "Work to Start on 63 MW Solar Plant in Salinas." Caribbean Business. http://www.caribbeanbusinesspr.com/news03.php?nt id=49337\&ct id=1. Accessed December 8, 2010.

${ }^{14}$ Calculations for this analysis assume the $30 \%$ federal tax credit incentive would be captured for the systems.
} 

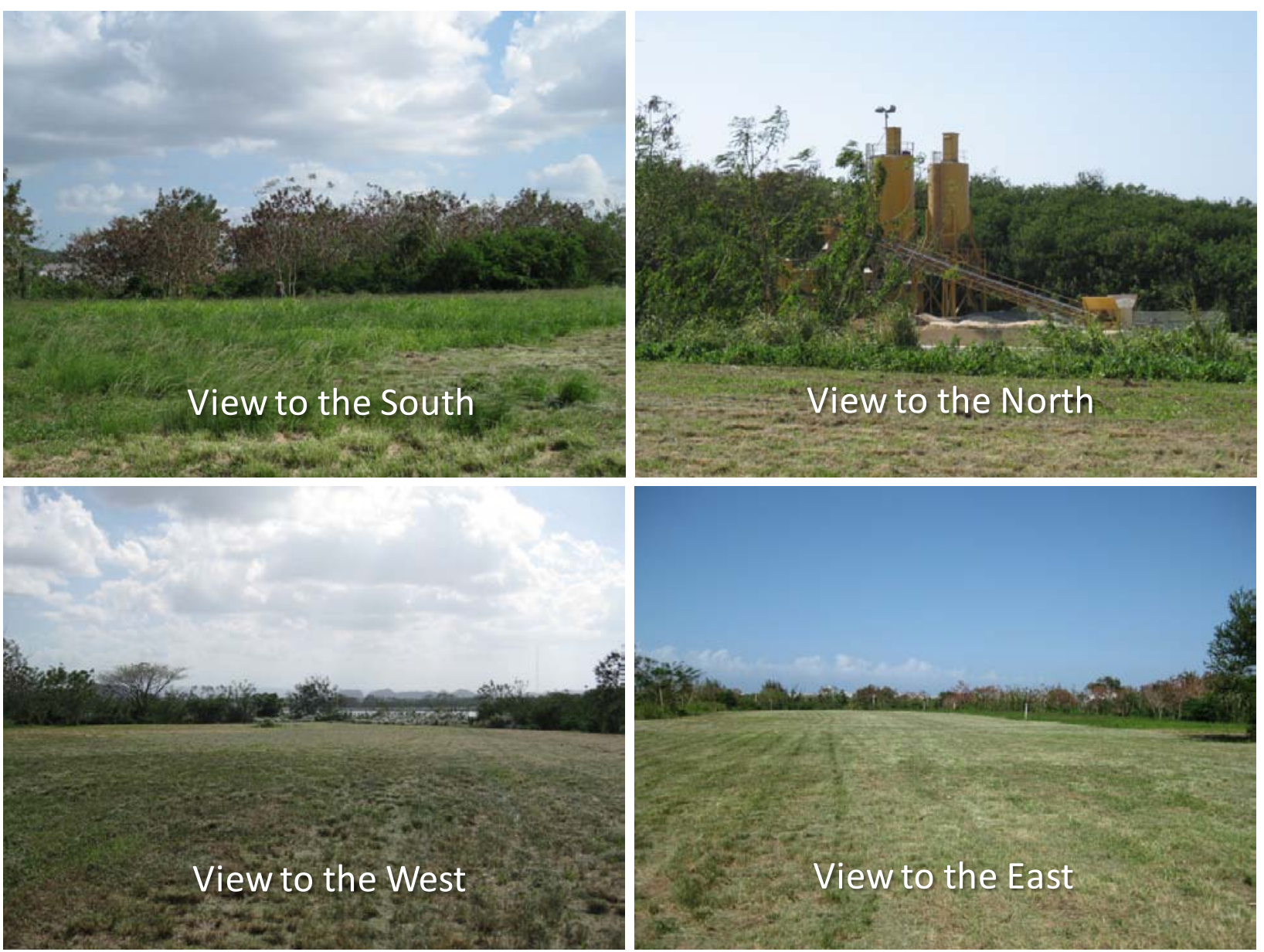

Figure 5. Views of the feasible area for PV at the Cataño Landfill

Credits: Gail Mosey, NREL

As shown in Figure 5, there are large expanses of flat unshaded land, and the landfill is closed and capped, which makes it a great candidate for a PV system. It should be noted that sections of the impermeable plastic liner of the landfill cap were exposed, as shown in Figure 6. This needs to be remedied before a PV system can be installed because the plastic liner will degrade and fail when exposed to the ultraviolet rays from the sun. 

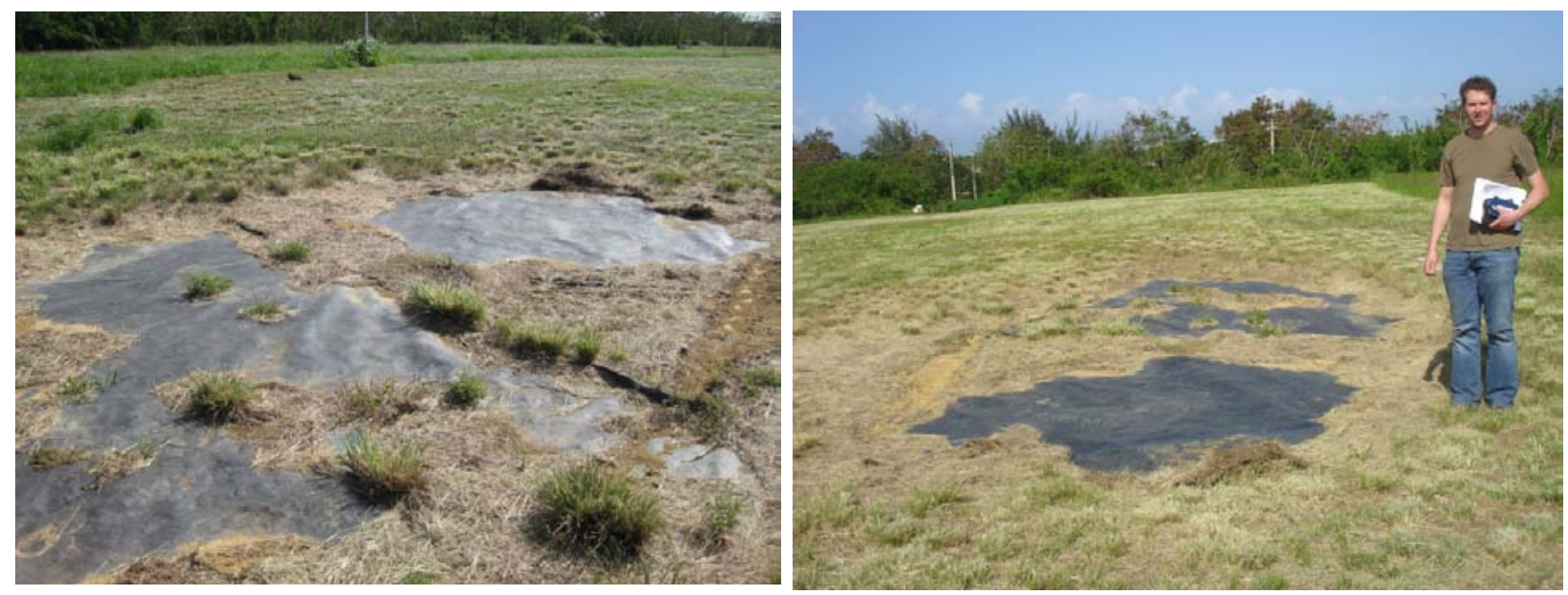

Figure 6. Views of the exposed impermeable plastic liner of the Cataño Landfill cap

Credits: Gail Mosey, NREL (left); Philip Flax, EPA (right)

There are electrical points around the site where a PV system could tie into. Construction could potentially be started on this site immediately after the landfill cap is repaired. This site would need to have a ballast-mounted system implemented, as ground disturbances are not permitted. The site was relatively well kept and mowed at the time of the site visit, although, some of the grass on the south side of the landfill was longer than the rest of the site. As shown in Figure 7, there were several smaller trees growing on the landfill. Having trees on a closed, capped landfill is not advisable since the roots may disturb the landfill cap. Furthermore, trees will shade a potential PV system. These trees should be removed prior to installing a PV system.

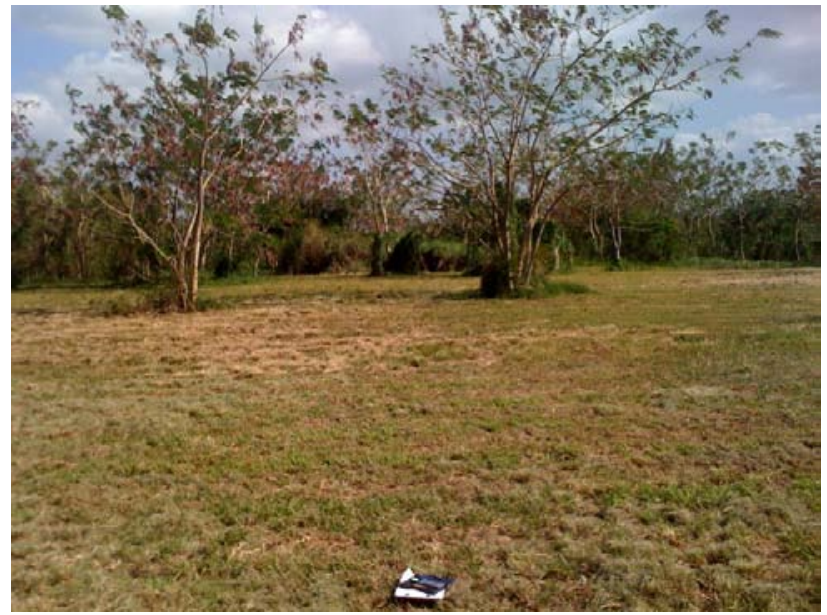

Figure 7. View of two of the trees that need to be removed at the Cataño Landfill

Credit: Jimmy Salasovich, NREL

The Cataño Landfill has the second largest available area for a PV system of the eight landfills that were assessed. The total feasible area for PV is $22,786 \mathrm{~m}^{2}$. Figure 8 shows the Cataño Landfill taken from Google Earth; the feasible area for PV is shaded in orange. As shown, there is one relatively large area at the Cataño Landfill that is feasible for PV. See Table 23 for the ground-mounted PV system possibilities at the Cataño Landfill. The three options outline the 
types of solar technology that could potentially be used. The economics of the potential systems were analyzed assuming that a PPA with PREPA would be used and PREPA would buy back the electricity at an electric rate of $\$ 0.13 / \mathrm{kWh}$. The cost of PV systems in Puerto Rico varies and therefore two cost estimates and associated simple paybacks are given.

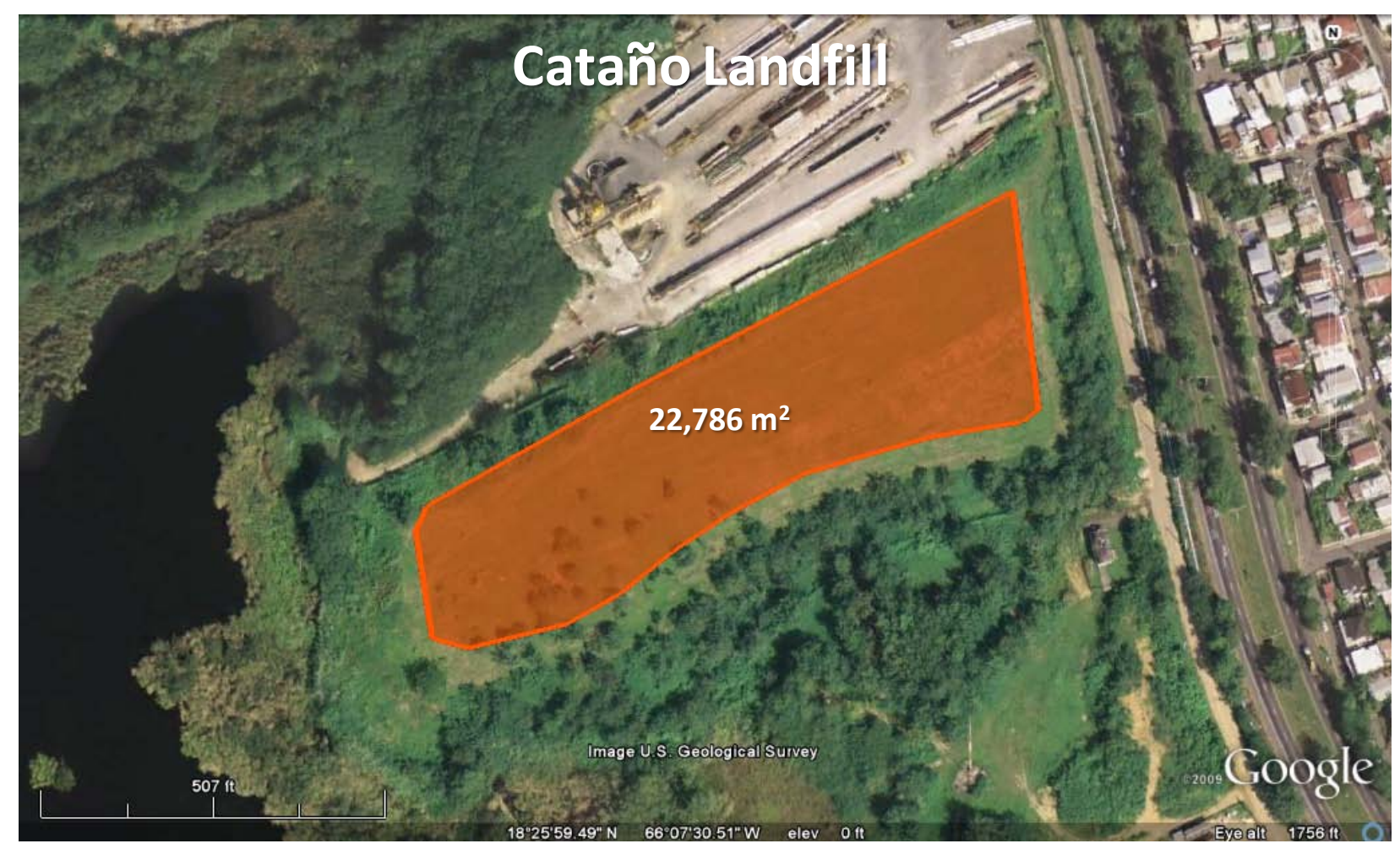

Figure 8. Aerial view of the feasible area for PV at the Cataño Landfill

Credit: Google Earth 
Table 3. Cataño Landfill Site PV System Options

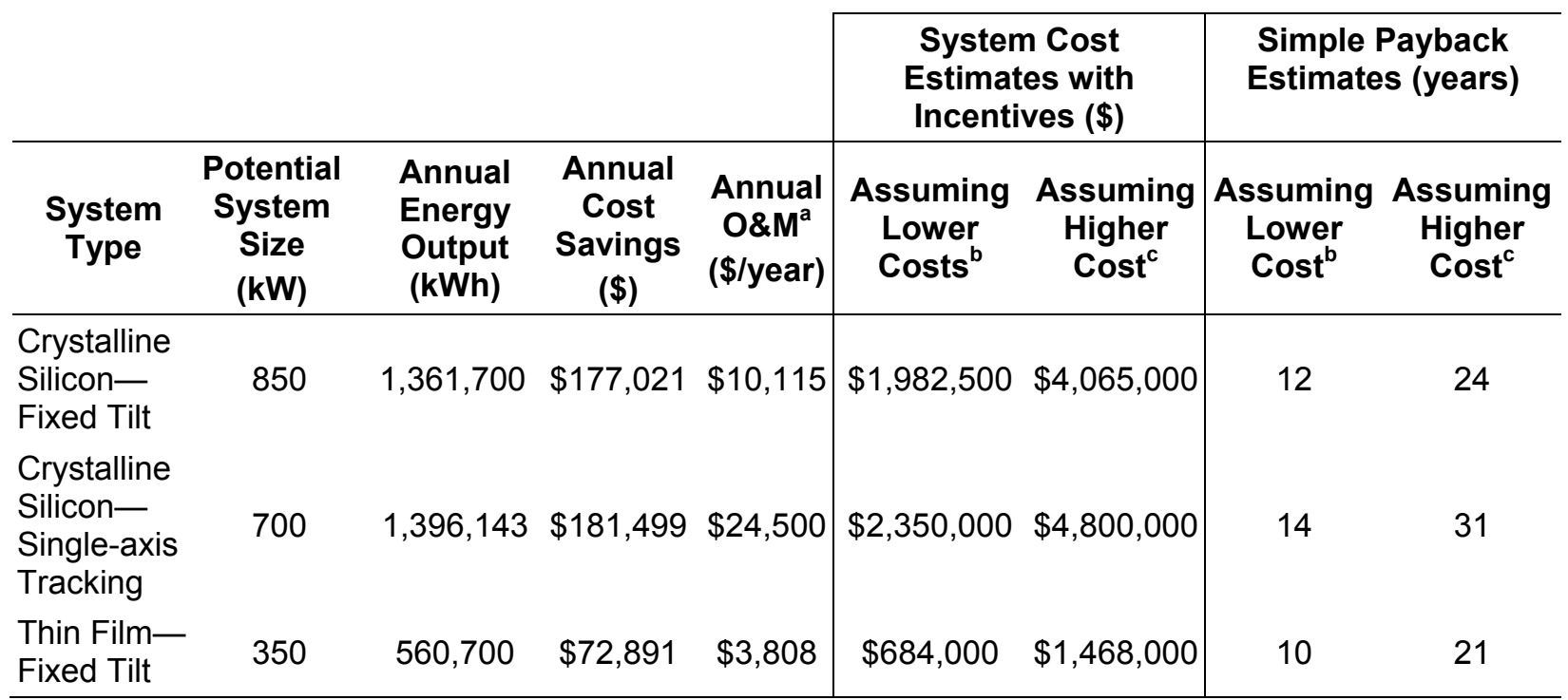

${ }^{a}$ Annual O\&M is based on the higher cost assumptions.

${ }^{b} \$ 3.50 / \mathrm{W}$ is for a crystalline silicon fixed-tilt system. Single-axis tracking systems costs are assumed to be $\$ 5.00 / \mathrm{W}$ and thin-film systems are assumed to be $\$ 3.20 / \mathrm{W}$.

${ }^{\mathrm{c}} \$ 7.00 / \mathrm{W}$ is for a crystalline silicon fixed-tilt system. Single-axis tracking systems costs are assumed to be $\$ 10.00 / \mathrm{W}$ and thin-film systems are assumed to be $\$ 6.40 / \mathrm{W}$.

\subsubsection{Guayama Landfill PV System}

The city of Guayama is located on the southern coast of Puerto Rico. The approximate population is currently 44,000. The Guayama Landfill is located to the west of San Juan and just south of interstate PR-54. The Guayama Landfill is visible from interstate PR-54. Figure 9 shows various views of the Guayama Landfill. 

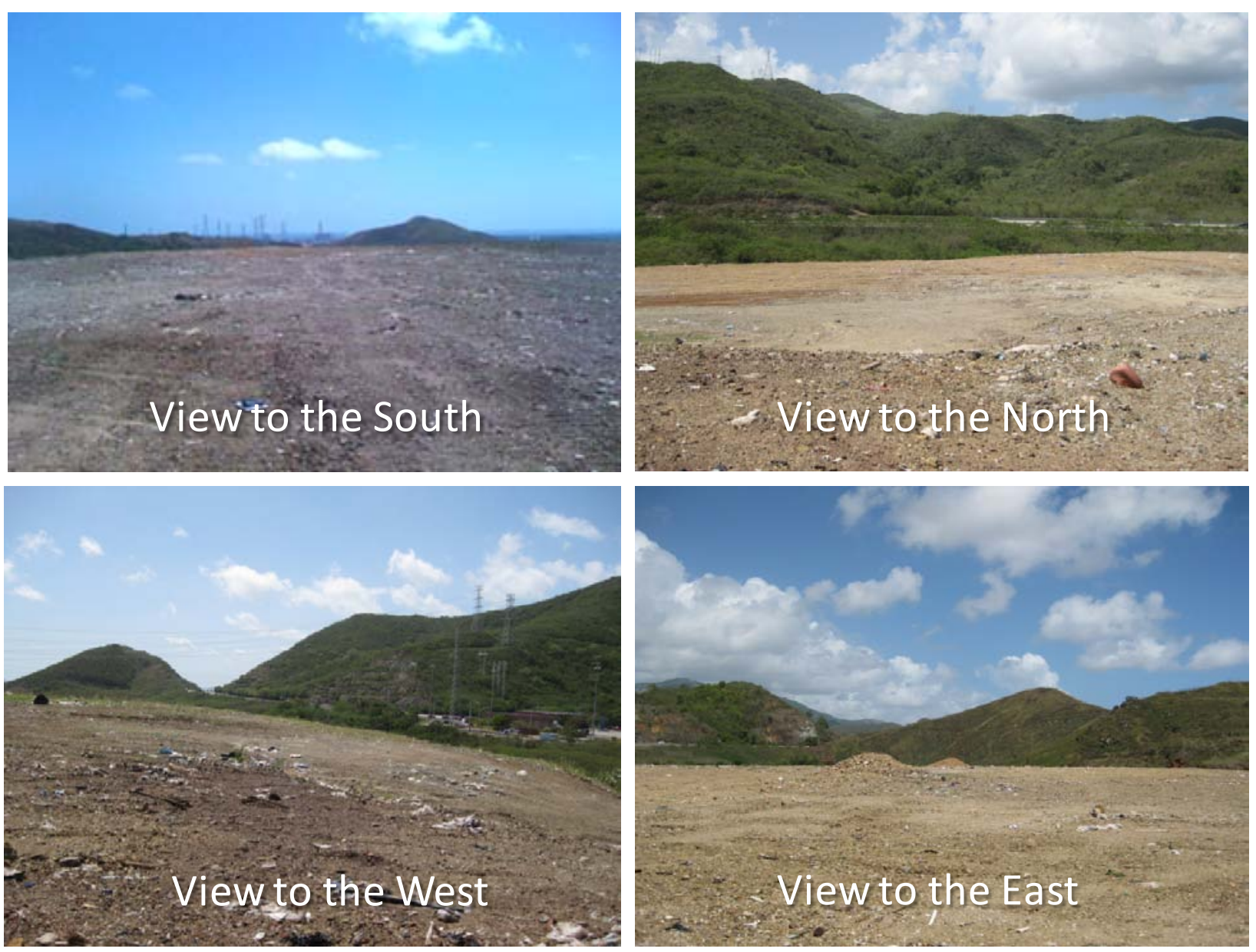

Figure 9. Views of the feasible area for PV at the Guayama Landfill

Credits: Gail Mosey, NREL (north, west, and east); Jimmy Salasovich, NREL (south)

As shown in Figure 9, there are large expanses of flat unshaded land. However, the Guayama Landfill is still active and is scheduled to be closed in 2011. ${ }^{15}$ There are electrical points a relatively short distance away that a PV system could tie into. Construction could potentially be started on this site once the landfill is closed and capped. This site would need to have a ballastmounted system implemented on the landfill, as ground disturbances are not permitted.

The Guayama Landfill has the fifth largest available area for a PV system of the eight landfills that were assessed. The total feasible area for PV is $12,011 \mathrm{~m}^{2}$. Figure 10 shows the Guayama Landfill taken from Google Earth; the feasible area for PV is shaded in orange. As shown, there is one relatively large area at the Guayama Landfill that is feasible for PV. See Table 4 for the ground-mounted PV system possibilities at the Guayama Landfill. The three options outline the types of solar technology that could potentially be used. The economics of the potential systems were analyzed assuming that a PPA with PREPA would be used and PREPA would buy back at an electric rate of $\$ 0.13 / \mathrm{kWh}$. The cost of PV systems in Puerto Rico varies and therefore two cost estimates and associated simple paybacks are given.

\footnotetext{
${ }^{15}$ The projected closure date is based upon a study done in 2004 by Malcolm Pirnie Assoc. for the Puerto Rico Solid Waste Management Authority.
} 


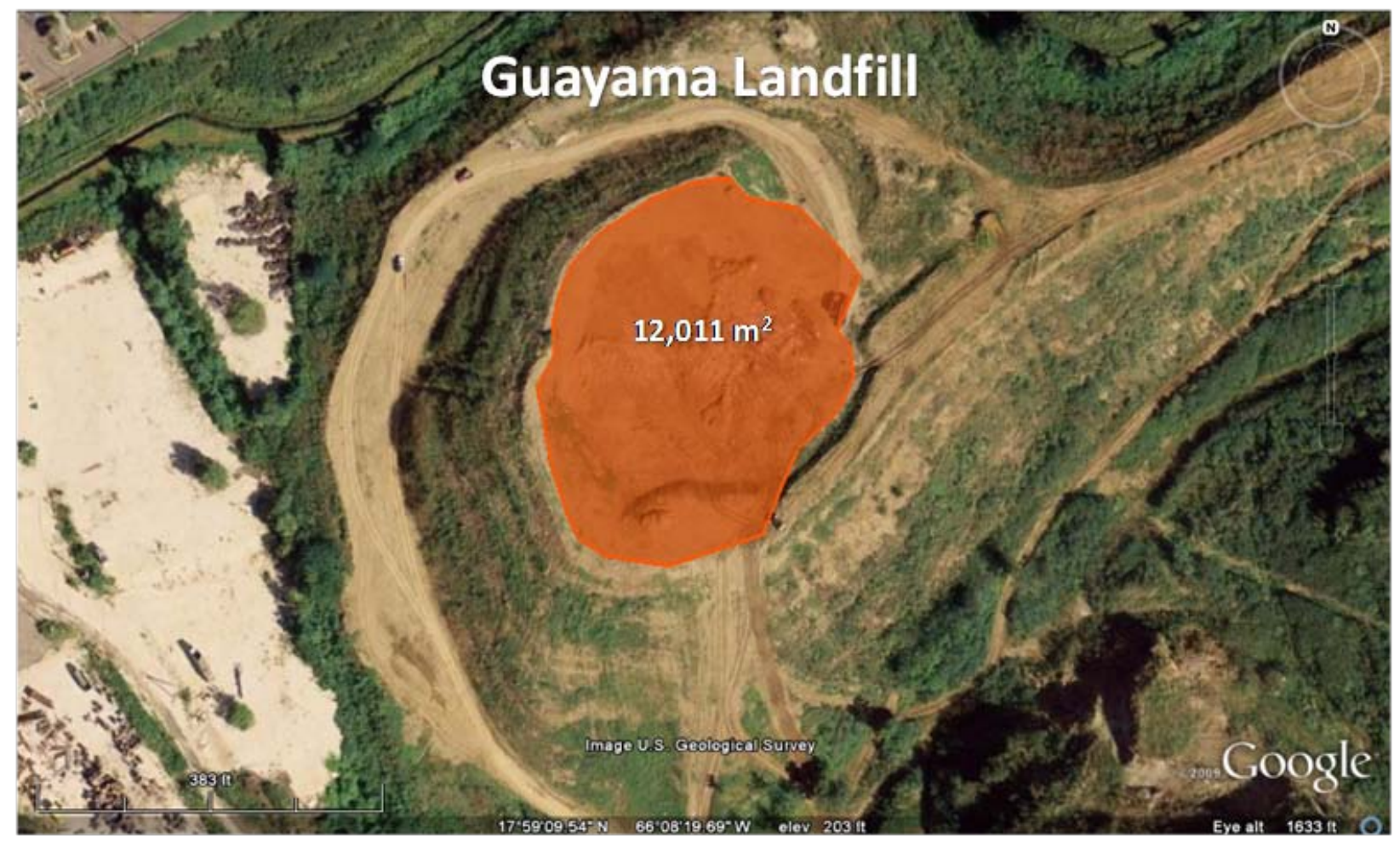

Figure 10. Aerial view of the feasible area for PV at the Guayama Landfill Credit: Google Earth 
Table 4. Guayama Landfill Site PV System Options

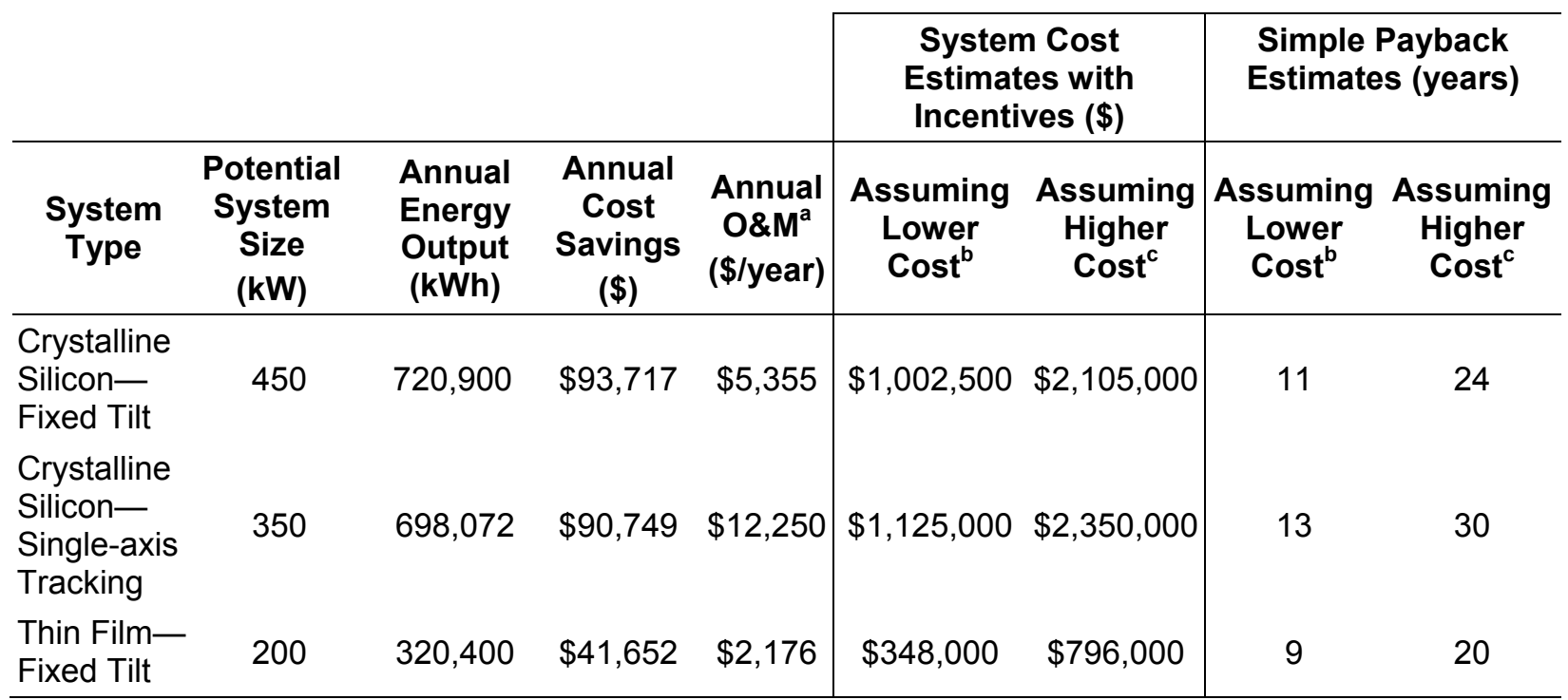

${ }^{a}$ Annual O\&M is based on the higher cost assumptions.

${ }^{b} \$ 3.50 / \mathrm{W}$ is for a crystalline silicon fixed-tilt system. Single-axis tracking systems costs are assumed to be $\$ 5.00 / \mathrm{W}$ and thin-film systems are assumed to be $\$ 3.20 / \mathrm{W}$.

${ }^{c} \$ 7.00 / \mathrm{W}$ is for a crystalline silicon fixed-tilt system. Single-axis tracking systems costs are assumed to be $\$ 10.00 / \mathrm{W}$ and thin-film systems are assumed to be $\$ 6.40 / \mathrm{W}$.

\subsubsection{Guaynabo Landfill PV System}

The city of Guaynabo is located in the northern half of Puerto Rico and is approximately 12 miles away from the northern shore. The approximate population is currently 100,000. The Guaynabo Landfill is located south of San Juan and just west of interstate PR-1. The Guaynabo Landfill is not a particularly visible site as it is nestled in the hills. Figure 11 shows various views of the Guaynabo Landfill. 

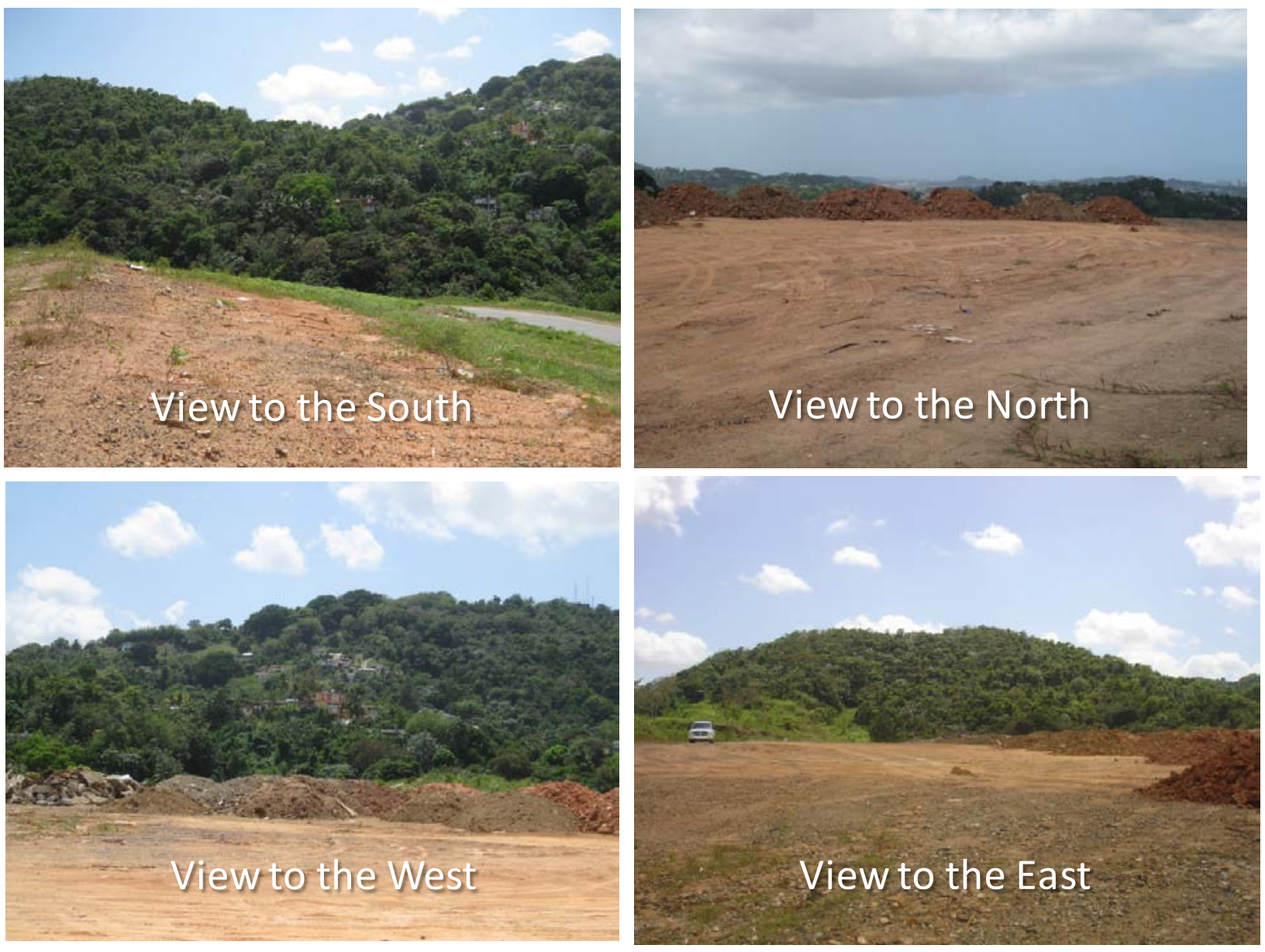

Figure 11. Views of the feasible area for PV at the Guaynabo Landfill

Credits: Gail Mosey, NREL (south, north, and west); Philip Flax, EPA (east)

As shown in Figure 11, the Guaynabo Landfill has limited areas of flat unshaded land. Figure 12 shows the majority of the Guaynabo Landfill is relatively hilly, which is not suitable for PV. There is a relatively small area that is suitable for installing a PV system. There are electrical points a relatively short distance away where a PV system could tie into. The landfill is closed and capped, so construction could be started on this site. This site would need to have a ballastmounted system implemented on the landfill, as ground disturbances are not permitted. 

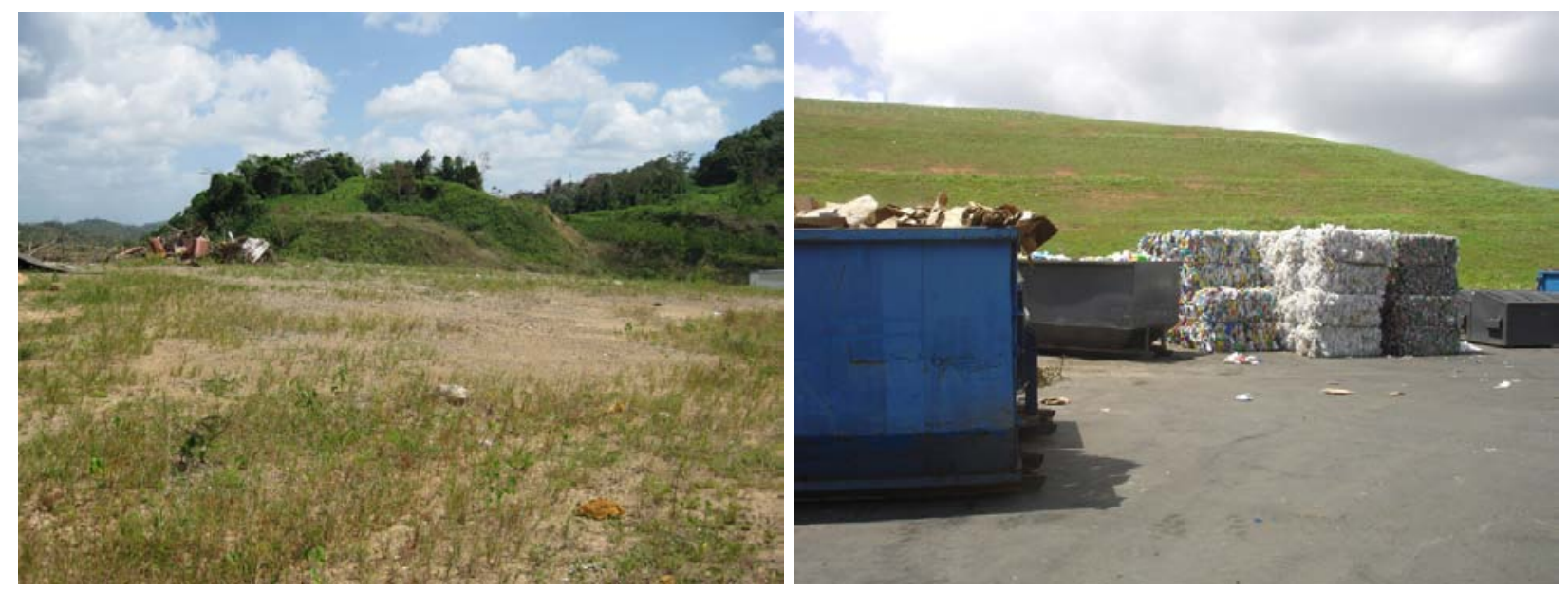

Figure 12. Views of the Guaynabo Landfill showing the hilly terrain

Credits: Gail Mosey, NREL (left); Philip Flax, EPA (right)

Guaynabo is a relatively progressive city in Puerto Rico, and the Guaynabo Landfill has a stateof-the-art recycling center, which is shown in Figure 13. The site has an electrical substation for the recycling center, and this is a possible electrical tie-in point for a PV system. As mentioned earlier, landfills generally use little or no electricity, so the electricity produced by a PV system would typically have to be sold back to the electrical provider. In the case of the Guaynabo Landfill, however, the recycling center's electrical use could be offset by a PV system. Furthermore, a PV system could be installed on the roof of the recycling center.

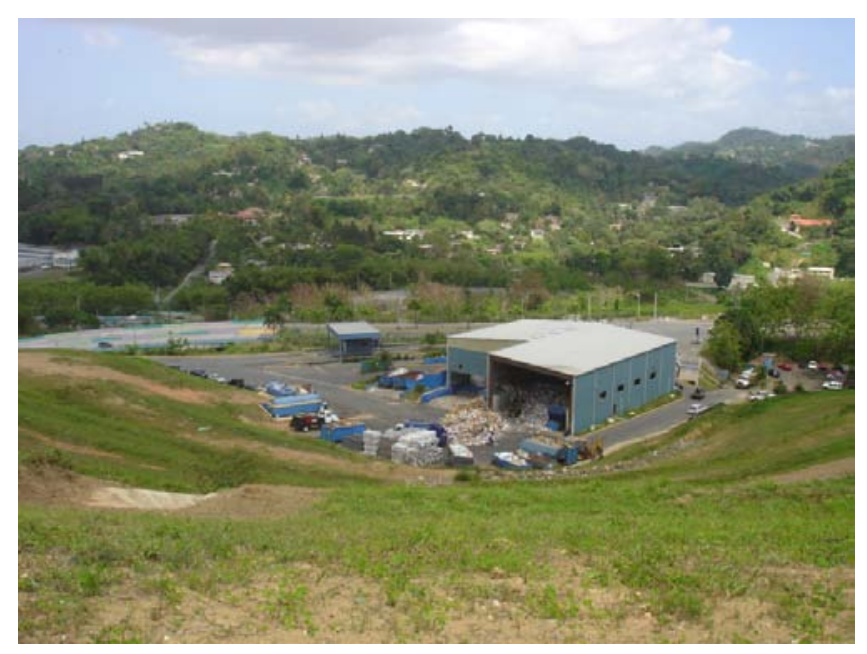

Figure 13. Guaynabo Landfill recycling center

Credit: Philip Flax, EPA 
The Guaynabo Landfill has the smallest available area for a PV system of the eight feasible landfills that were assessed. The total feasible area for PV is $8,195 \mathrm{~m}^{2}$, which includes a portion of the recycling center's roof. Figure 14 shows the Guaynabo Landfill and recycling center taken from Google Earth; the feasible area for PV is shaded in orange. As shown, there is one relatively large area at the Guaynabo Landfill that is feasible for PV and one smaller area on the roof of the Guaynabo recycling center. See Table 5 for the ground-mounted PV system possibilities for the Guaynabo Landfill. The three options outline the types of solar technology that could potentially be used. See Table 6 for the roof-mounted PV system possibilities for the Guaynabo Landfill recycling center. The two options outline the types of solar technology that could potentially be used. The economics of the potential systems were analyzed assuming that a PPA with PREPA would be used and PREPA would buy back at an electric rate of $\$ 0.13 / \mathrm{kWh}$. The cost of PV systems in Puerto Rico varies and therefore two cost estimates and associated simple paybacks are given.

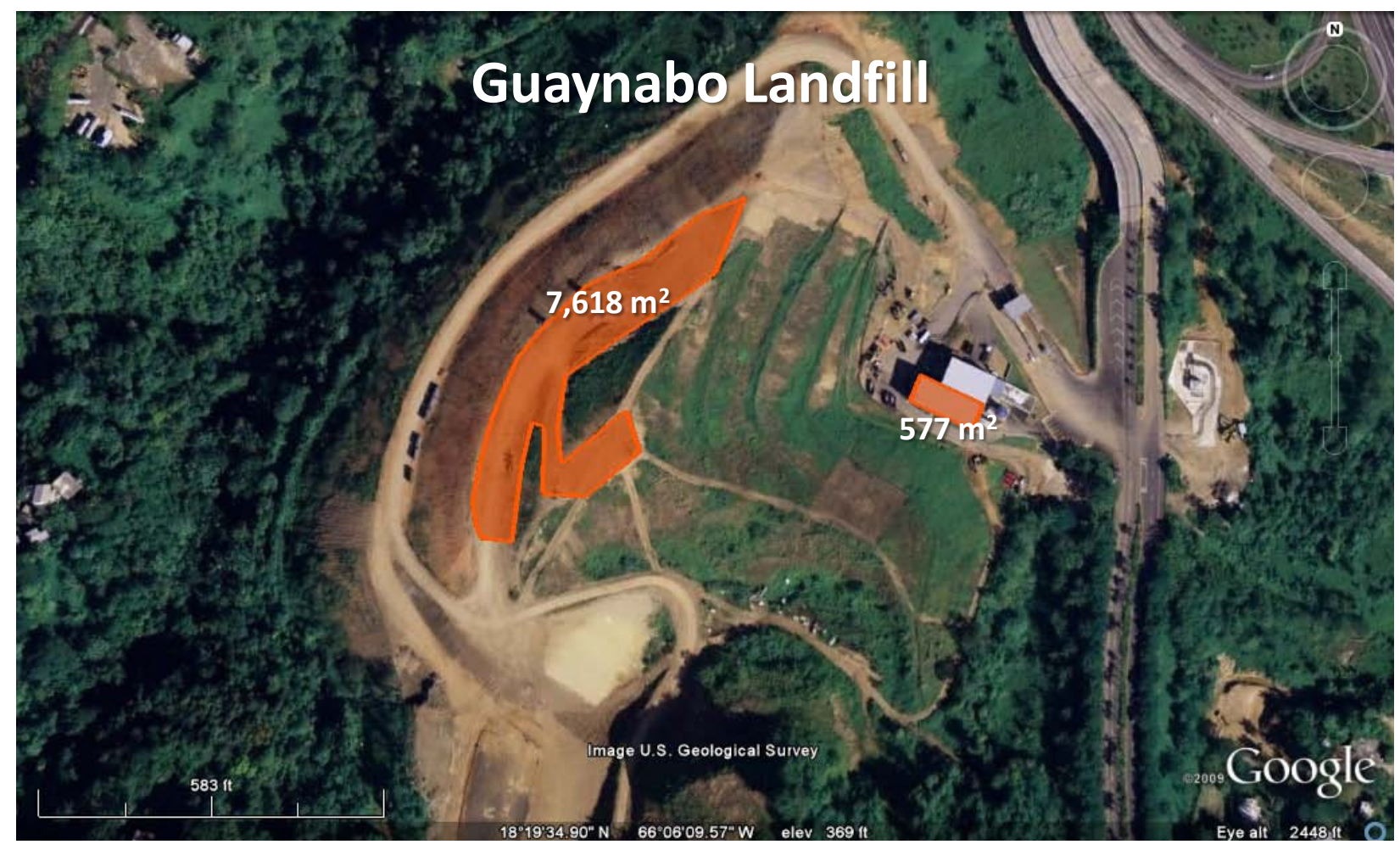

Figure 14. Aerial view of the feasible area for PV at the Guaynabo Landfill and recycling center Credit: Google Earth 
Table 5. Guaynabo Landfill Site Ground-mounted PV System Options

\begin{tabular}{|c|c|c|c|c|c|c|c|c|}
\hline \multirow[b]{2}{*}{$\begin{array}{l}\text { System } \\
\text { Type }\end{array}$} & \multirow[b]{2}{*}{$\begin{array}{l}\text { Potential } \\
\text { System } \\
\text { Size } \\
(k W)\end{array}$} & \multirow[b]{2}{*}{$\begin{array}{l}\text { Annual } \\
\text { Energy } \\
\text { Output } \\
\text { (kWh) }\end{array}$} & \multirow[b]{2}{*}{$\begin{array}{c}\text { Annual } \\
\text { Cost } \\
\text { Savings } \\
(\$) \\
\end{array}$} & \multirow[b]{2}{*}{$\begin{array}{l}\text { Annual } \\
\text { O\&M }^{a} \\
\text { (\$/year) }\end{array}$} & \multicolumn{2}{|c|}{$\begin{array}{l}\text { System Cost } \\
\text { Estimates with } \\
\text { Incentives (\$) }\end{array}$} & \multicolumn{2}{|c|}{$\begin{array}{l}\text { Simple Payback } \\
\text { Estimates (years) }\end{array}$} \\
\hline & & & & & $\begin{array}{l}\text { Assuming } \\
\text { Lower } \\
\text { Cost }^{\text {b }}\end{array}$ & $\begin{array}{c}\text { Assuming } \\
\text { Higher }^{c} \\
\text { Cost }^{c}\end{array}$ & $\begin{array}{l}\text { Assuming } \\
\text { Lower }^{\text {Cost }}\end{array}$ & $\begin{array}{l}\text { Assuming } \\
\text { Higher } \\
\text { Cost }^{\mathrm{c}}\end{array}$ \\
\hline $\begin{array}{l}\text { Crystalline } \\
\text { Silicon- } \\
\text { Fixed Tilt }\end{array}$ & 300 & 480,600 & $\$ 62,478$ & $\$ 3,570$ & $\$ 635,000$ & $\$ 1,370,000$ & 10 & 23 \\
\hline $\begin{array}{l}\text { Crystalline } \\
\text { Silicon- } \\
\text { Single-axis } \\
\text { Tracking }\end{array}$ & 250 & 498,623 & $\$ 64,821$ & $\$ 8,750$ & $\$ 775,000$ & $\$ 1,650,000$ & 13 & 29 \\
\hline $\begin{array}{l}\text { Thin Film- } \\
\text { Fixed Tilt }\end{array}$ & 100 & 160,200 & $\$ 20,826$ & $\$ 1,088$ & $\$ 124,000$ & $\$ 348,000$ & 6 & 18 \\
\hline
\end{tabular}

${ }^{\mathrm{a}}$ Annual O\&M is based on the higher cost assumptions.

${ }^{\mathrm{b}} \$ 3.50 / \mathrm{W}$ is for a crystalline silicon fixed-tilt system. Single-axis tracking systems costs are assumed to be $\$ 5.00 / \mathrm{W}$ and thin-film systems are assumed to be $\$ 3.20 / \mathrm{W}$.

${ }^{c} \$ 7.00 / \mathrm{W}$ is for a crystalline silicon fixed-tilt system. Single-axis tracking systems costs are assumed to be $\$ 10.00 / \mathrm{W}$ and thin-film systems are assumed to be $\$ 6.40 / \mathrm{W}$.

Table 6. Guaynabo Recycling Center Roof-mounted PV System Options

\begin{tabular}{|c|c|c|c|c|c|c|c|c|}
\hline \multirow[b]{2}{*}{$\begin{array}{l}\text { System } \\
\text { Type }\end{array}$} & \multirow[b]{2}{*}{$\begin{array}{l}\text { Potential } \\
\text { System } \\
\text { Size } \\
(k W)\end{array}$} & \multirow[b]{2}{*}{$\begin{array}{c}\text { Annual } \\
\text { Energy } \\
\text { Output } \\
\text { (kWh) }\end{array}$} & \multirow[b]{2}{*}{$\begin{array}{c}\text { Annual } \\
\text { Cost } \\
\text { Savings } \\
(\$) \\
\end{array}$} & \multirow[b]{2}{*}{$\begin{array}{c}\text { Annual } \\
\text { O\&M }^{a} \\
\text { (\$/year) }\end{array}$} & \multicolumn{2}{|c|}{$\begin{array}{c}\text { System Cost } \\
\text { Estimates with } \\
\text { Incentives (\$) }\end{array}$} & \multicolumn{2}{|c|}{$\begin{array}{l}\text { Simple Payback } \\
\text { Estimates (years) }\end{array}$} \\
\hline & & & & & $\begin{array}{l}\text { Assuming } \\
\text { Lower } \\
\text { Cost }^{\mathrm{b}}\end{array}$ & $\begin{array}{c}\text { Assuming } \\
\text { Higher } \\
\text { Cost }^{c}\end{array}$ & $\begin{array}{c}\text { Assuming } \\
\text { Lower } \\
\text { Cost }^{\mathrm{b}}\end{array}$ & $\begin{array}{c}\text { Assuming } \\
\text { Higher } \\
\text { Cost }^{c}\end{array}$ \\
\hline $\begin{array}{l}\text { Crystalline } \\
\text { Silicon- } \\
\text { Roof } \\
\text { Mounted }\end{array}$ & 50 & 80,100 & $\$ 10,413$ & $\$ 793$ & $\$ 110,000$ & $\$ 226,550$ & 11 & 24 \\
\hline $\begin{array}{l}\text { Thin Film- } \\
\text { Roof } \\
\text { Mounted }\end{array}$ & 25 & 40,050 & $\$ 5,207$ & $\$ 371$ & $\$ 27,000$ & $\$ 43,650$ & 5 & 9 \\
\hline
\end{tabular}

${ }^{a}$ Annual O\&M is based on the higher cost assumptions.

${ }^{b} \$ 6.00 / \mathrm{W}$ is for a crystalline silicon roof-mounted system. Thin-film roof-mounted systems are assumed to be $\$ 5.40 / \mathrm{W}$.

${ }^{c} \$ 9.33 / \mathrm{W}$ is for a crystalline silicon roof-mounted system. Thin-film roof-mounted systems are assumed to be $\$ 8.73 / \mathrm{W}$.

\subsubsection{Salinas Landfill PV System}

The city of Salinas is located on the southern coast of Puerto Rico. The approximate population is currently 44,000. The Salinas Landfill is not a feasible site for a PV system because of the hilly terrain at the site. Figure 15 shows various views of the hilly terrain at the Salinas Landfill. 
The Salinas Landfill is active and, due to a recent expansion, is not scheduled to close until 2032. ${ }^{16}$ Figure 16 is an image of the Salinas Landfill taken from Google Earth.
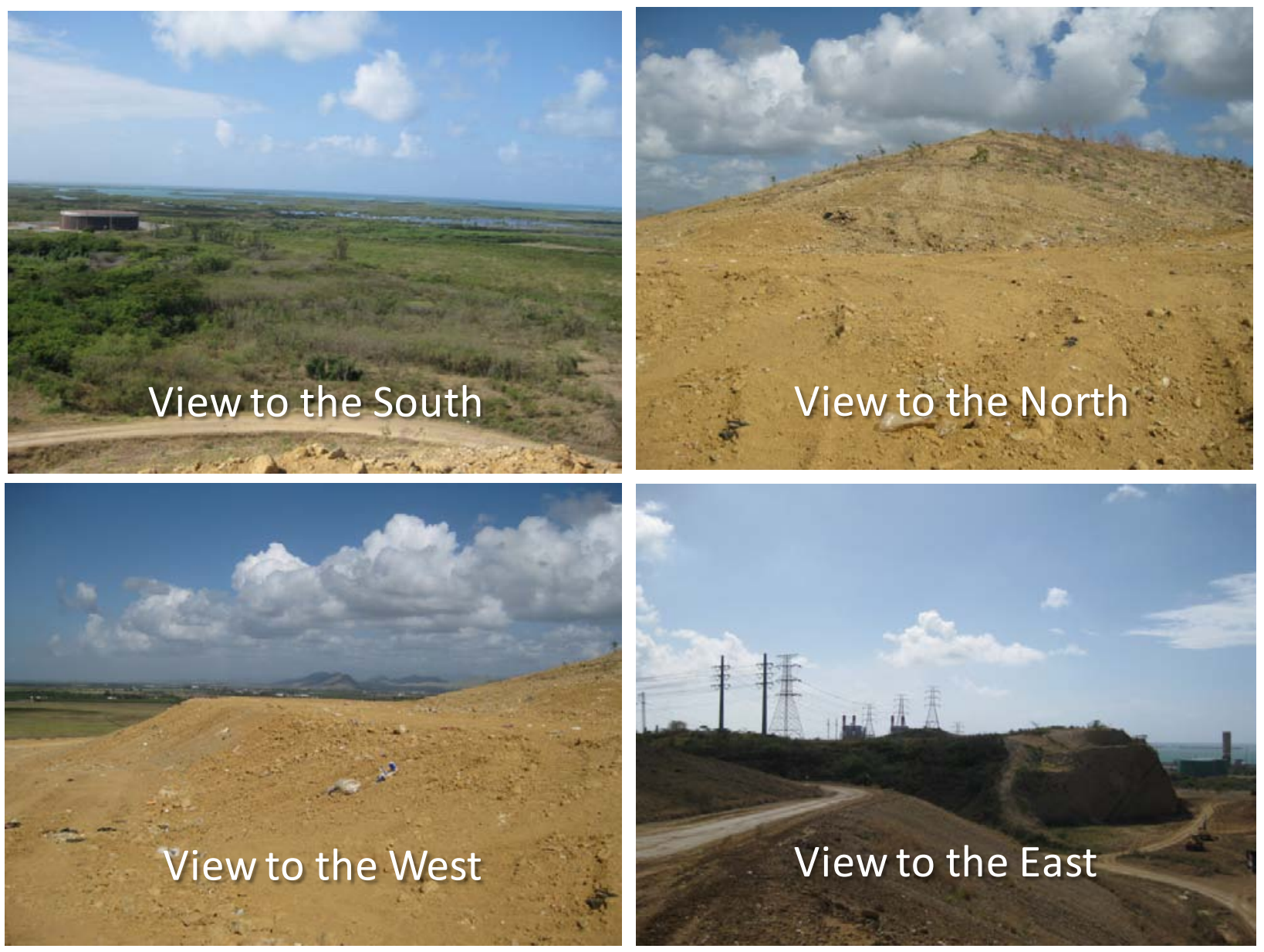

Figure 15. Views of the Salinas Landfill showing the hilly terrain

Credits: Gail Mosey, NREL

\footnotetext{
${ }^{16}$ The projected closure date is based upon a study done in 2004 by Malcolm Pirnie Assoc. for the Puerto Rico Solid Waste Management Authority.
} 


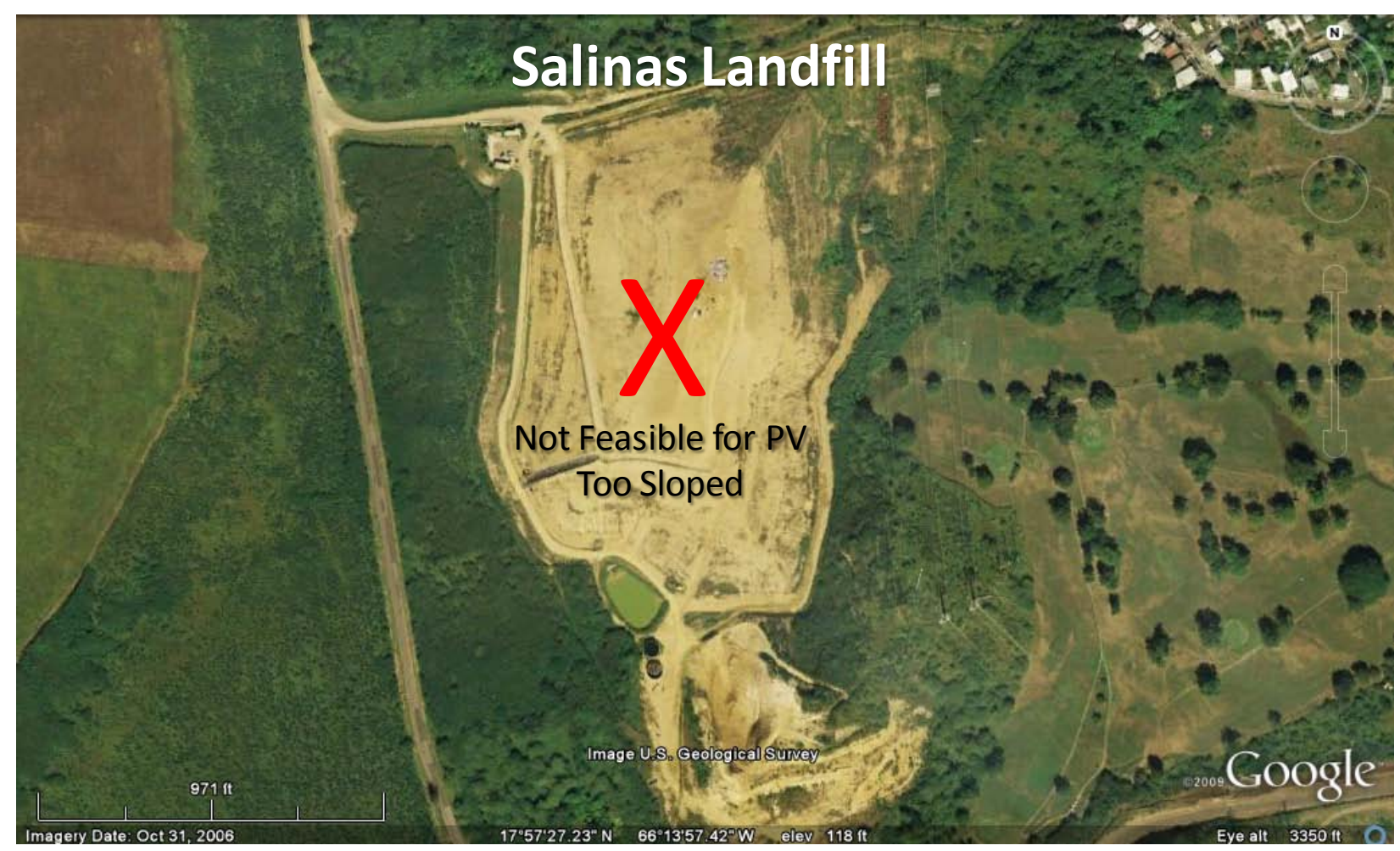

Figure 16. Aerial view of the Salinas Landfill with no feasible area for PV

Credit: Google Earth

\subsubsection{San Juan Landfill PV System}

San Juan is the capital city of Puerto Rico and is located on the north shore of the island. San Juan is the largest city in Puerto Rico, and the approximate population is currently 433,000. The San Juan Landfill is located in the south of the city and is closed and capped. The landfill is highly visible from the city and from surrounding highways, including Interstate PR-22. Figure 17 shows a $360^{\circ}$ view of the San Juan Landfill and an exploded view to the south. 


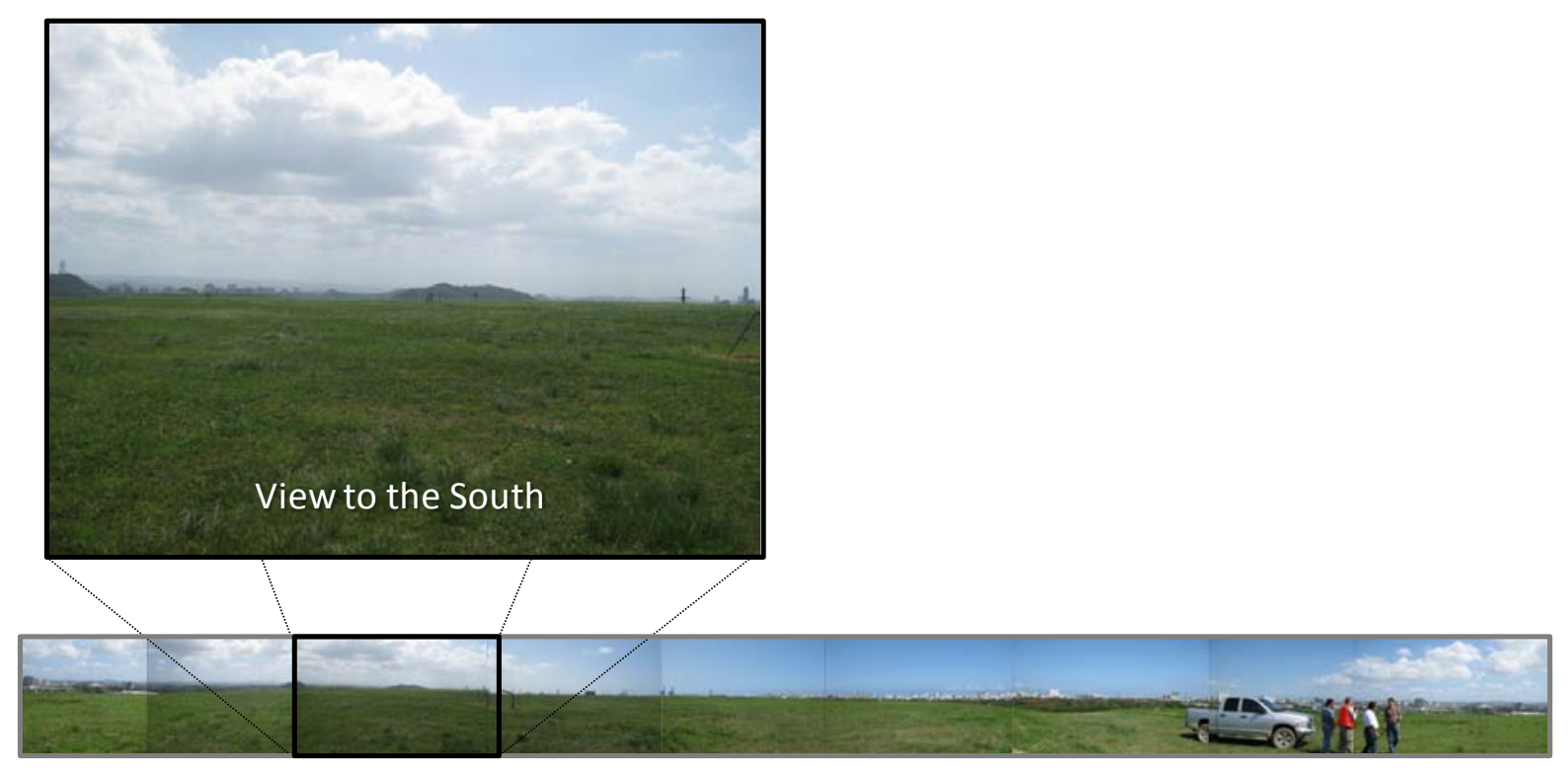

Figure $17.360^{\circ}$ view of the feasible area for PV at the San Juan Landfill

Credit: Gail Mosey, NREL

As shown in Figure 17, there are large expanses of flat unshaded land, and the landfill is closed and capped, which makes it a great candidate for a PV system. There are electrical lines on the site where a PV system could tie into. Construction could potentially start on this site immediately. This site would need to have a ballast-mounted system implemented, as ground disturbances are not permitted. The site was well kept and mowed at the time of the site visit. There is good storm water control, which creates more stable ground conditions that are less likely to have settling issues. This is important for PV systems since settling could damage or destroy parts of the PV system. There currently is a golf driving range on a relatively small area on the north side of the landfill, which is shown in Figure 18.

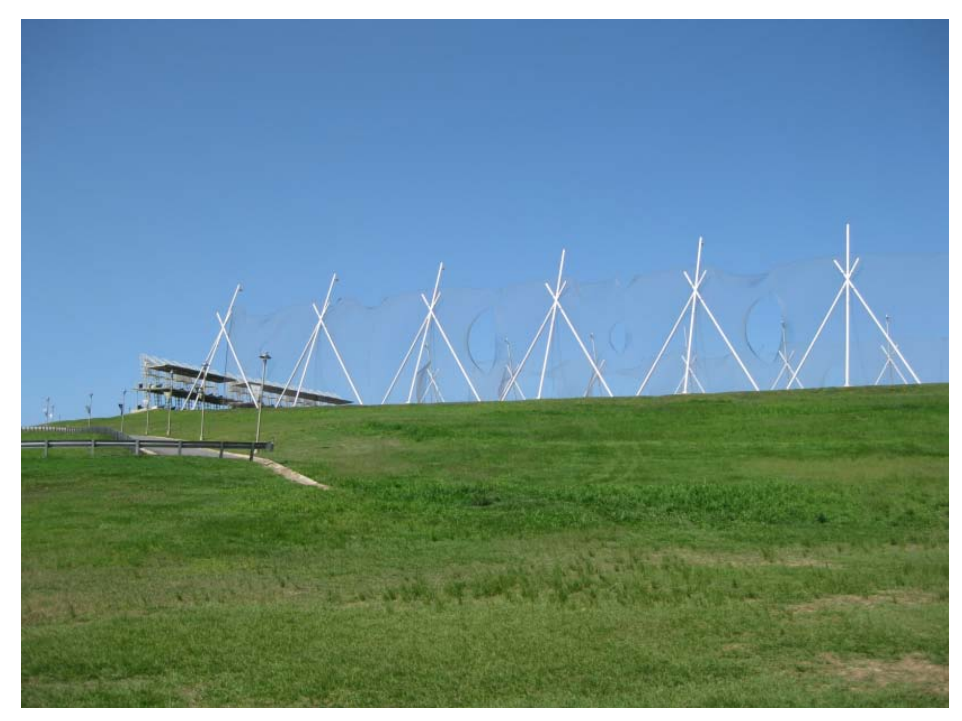

Figure 18. Golf driving range at the San Juan Landfill

Credit: Gail Mosey, NREL 
The San Juan Landfill has by far the largest available area for a PV system of the eight landfills that were assessed. With a total feasible area for PV of $195,290 \mathrm{~m}^{2}$, it is over eight times larger than the feasible PV area at Cataño Landfill, the second largest potential area. Figure 19 shows the San Juan Landfill taken from Google Earth; the feasible area for PV is shaded in orange. As shown, there are four areas at the San Juan Landfill that are feasible for PV. The northernmost area currently has a golf driving range that is shaded in green. This area would be suitable for $\mathrm{PV}$ if the golf driving range were ever to be removed. The golf driving range takes up approximately $7.1 \%$ of the total usable area for PV. The other three regions are relatively closely spaced but are separated by slopes that are too steep for PV. See Table 7 for the ground-mounted PV system possibilities for the San Juan Landfill, which includes all four areas and assuming the golf course area is used for PV. The three options outline the types of solar technology that could potentially be used. The economics of the potential systems were analyzed assuming that a PPA with PREPA would be used and PREPA would buy back at an electric rate of $\$ 0.13 / \mathrm{kWh}$. The cost of PV systems in Puerto Rico varies and therefore two cost estimates and associated simple paybacks are given.

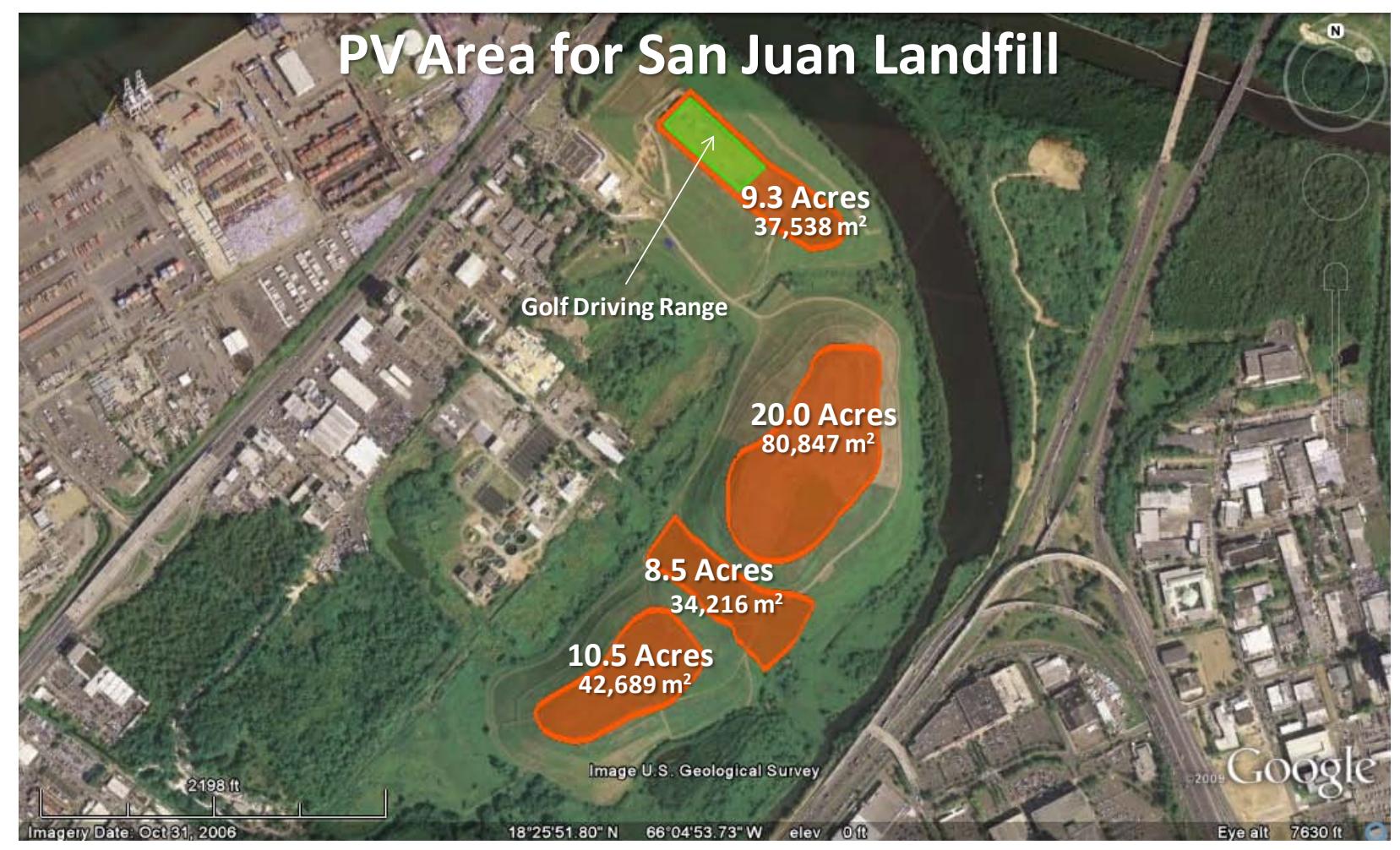

Figure 19. Aerial view of the feasible area for PV at the San Juan Landfill

Credit: Google Earth 
Table 7. San Juan Landfill Site PV System Options

\begin{tabular}{|c|c|c|c|c|c|c|c|c|}
\hline \multirow[b]{2}{*}{$\begin{array}{l}\text { System } \\
\text { Type }\end{array}$} & \multirow[b]{2}{*}{$\begin{array}{c}\text { Potential } \\
\text { System } \\
\text { Size } \\
(\mathbf{k W}) \\
\end{array}$} & \multirow[b]{2}{*}{$\begin{array}{c}\text { Annual } \\
\text { Energy } \\
\text { Output } \\
\text { (kWh) }\end{array}$} & \multirow[b]{2}{*}{$\begin{array}{c}\text { Annual } \\
\text { Cost } \\
\text { Savings } \\
(\$)\end{array}$} & \multirow[b]{2}{*}{$\begin{array}{c}\text { Annual } \\
\text { O\&M } \\
\text { (\$/year) }\end{array}$} & \multicolumn{2}{|c|}{$\begin{array}{l}\text { System Cost Estimates } \\
\text { with Incentives (\$) }\end{array}$} & \multicolumn{2}{|c|}{$\begin{array}{c}\text { Simple Payback } \\
\text { Estimates } \\
\text { (years) }\end{array}$} \\
\hline & & & & & $\begin{array}{l}\text { Assuming } \\
\text { Lower Cost }^{b}\end{array}$ & $\begin{array}{c}\text { Assuming } \\
\text { Higher } \\
\text { Cost }^{\mathrm{c}}\end{array}$ & $\begin{array}{l}\text { Assum- } \\
\text { ing } \\
\text { Lower } \\
\text { Cost }^{\text {b }}\end{array}$ & $\begin{array}{c}\text { Assum- } \\
\text { ing } \\
\text { Higher } \\
\text { Cost }^{c}\end{array}$ \\
\hline $\begin{array}{l}\text { Crystalline } \\
\text { Silicon- } \\
\text { Fixed Tilt }\end{array}$ & 7,500 & $12,015,000$ & $\$ 1,561,950$ & $\$ 89,250$ & $\$ 18,275,000$ & $\$ 36,650,000$ & 12 & 25 \\
\hline $\begin{array}{l}\text { Crystalline } \\
\text { Silicon- } \\
\text { Single-axis } \\
\text { Tracking }\end{array}$ & 6,200 & $12,365,838$ & $\$ 1,607,559$ & $\$ 217,000$ & $\$ 21,600,000$ & $\$ 43,300,000$ & 14 & 31 \\
\hline $\begin{array}{l}\text { Thin Film- } \\
\text { Fixed Tilt }\end{array}$ & 3,200 & $5,126,400$ & $\$ 666,432$ & $\$ 34,816$ & $\$ 7,068,000$ & $\$ 14,236,000$ & 11 & 23 \\
\hline
\end{tabular}

${ }^{a}$ Annual O\&M is based on the higher cost assumptions.

b $\$ 3.50 / \mathrm{W}$ is for a crystalline silicon fixed-tilt system. Single-axis tracking systems costs are assumed to be $\$ 5.00 / \mathrm{W}$ and thin-film systems are assumed to be $\$ 3.20 / \mathrm{W}$.

${ }^{c} \$ 7.00 / \mathrm{W}$ is for a crystalline silicon fixed-tilt system. Single-axis tracking systems costs are assumed to be $\$ 10.00 / \mathrm{W}$ and thin-film systems are assumed to be $\$ 6.40 / \mathrm{W}$.

Landfill gas is created by all relatively newly capped landfills. The landfill gas at the San Juan Landfill is presently being flared. Figure 20 shows the San Juan Landfill gas flaring facility.

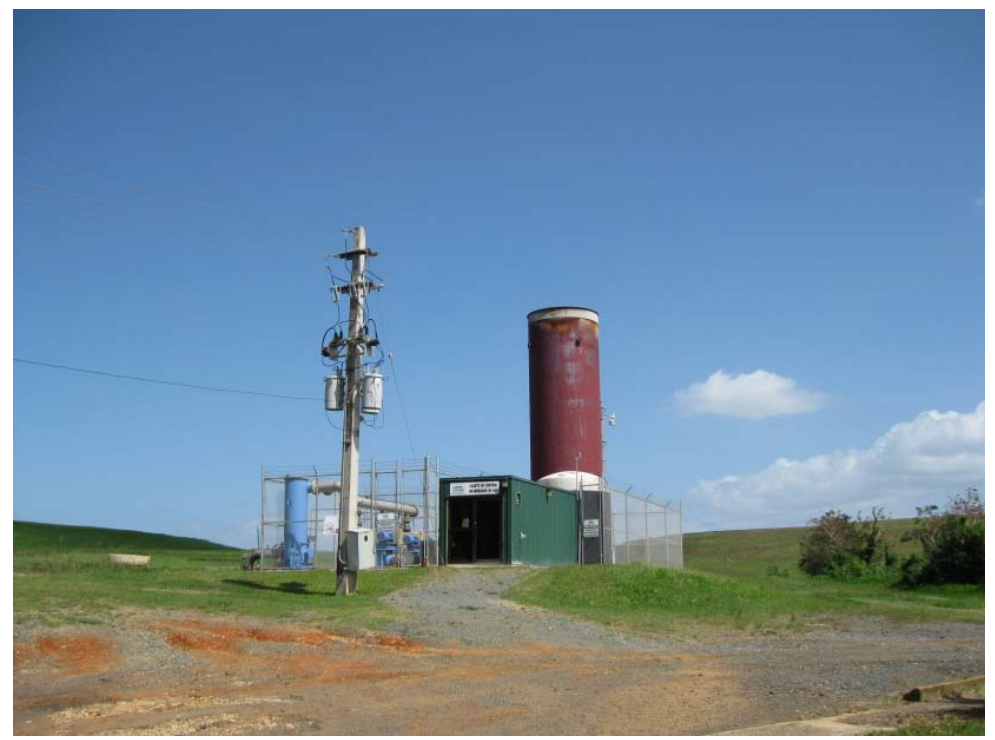

Figure 20. San Juan Landfill gas flaring facility

Credit: Gail Mosey, NREL

\subsubsection{Santa Isabel Landfill PV System}

The city of Santa Isabel is located on the southern coast of Puerto Rico. The approximate population is currently 18,000. The Santa Isabel Landfill is located northeast of San Juan just 
north of interstate PR-52. The Santa Isabel Landfill is somewhat visible from interstate PR-52, but otherwise the site is nestled in the hills. Figure 21 shows various views of the Santa Isabel Landfill.
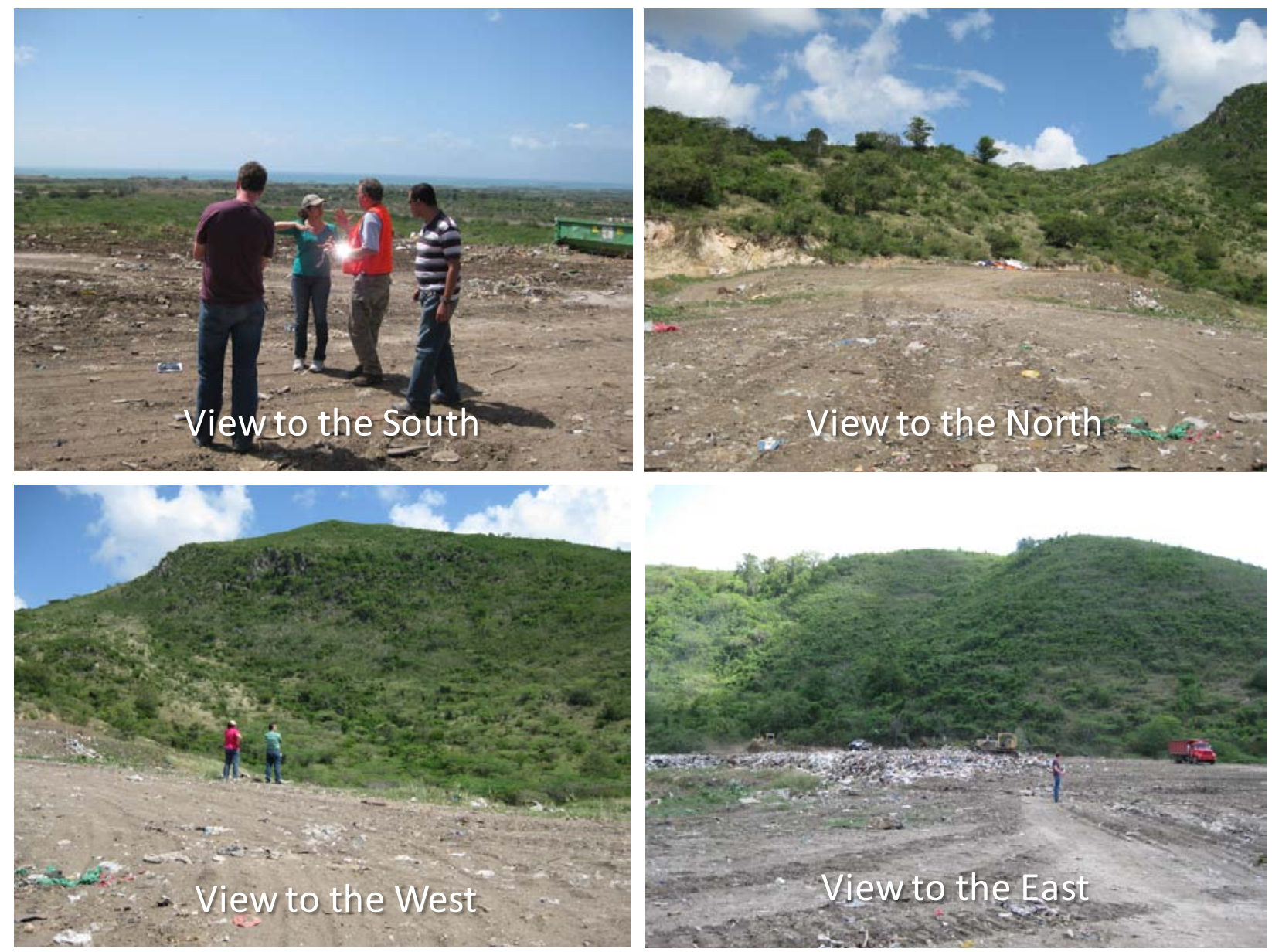

Figure 21. Views of the feasible area for PV at the Santa Isabel Landfill

Credits: Gail Mosey, NREL

As shown in Figure 21, there are large expanses of flat unshaded land; however, the Santa Isabel Landfill is still active. The projected close date is $2012 .{ }^{17}$ There are electrical points a relatively short distance away that a PV system could tie into. Construction could potentially be started on this site once the landfill is closed and capped. This site would need to have a ballast-mounted system implemented on the landfill, as ground disturbances are not permitted.

The Santa Isabel Landfill has the fourth largest available area for a PV system of the eight landfills that were assessed. The total feasible area for PV is $16,467 \mathrm{~m}^{2}$. Figure 22 shows the Santa Isabel Landfill taken from Google Earth; the feasible area for PV is shaded in orange. As shown, there is one relatively large area at the Santa Isabel Landfill that is feasible for PV. See Table 8 for the ground-mounted PV system possibilities for the Santa Isabel Landfill. The three

\footnotetext{
${ }^{17}$ The projected closure date is based upon a study done in 2004 by Malcolm Pirnie Assoc. for the Puerto Rico Solid Waste Management Authority.
} 
options outline the types of solar technology that could potentially be used. The economics of the potential systems were analyzed assuming that a PPA with PREPA would be used and PREPA would buy back at an electric rate of $\$ 0.13 / \mathrm{kWh}$. The cost of PV systems in Puerto Rico varies and therefore two cost estimates and associated simple paybacks are given.

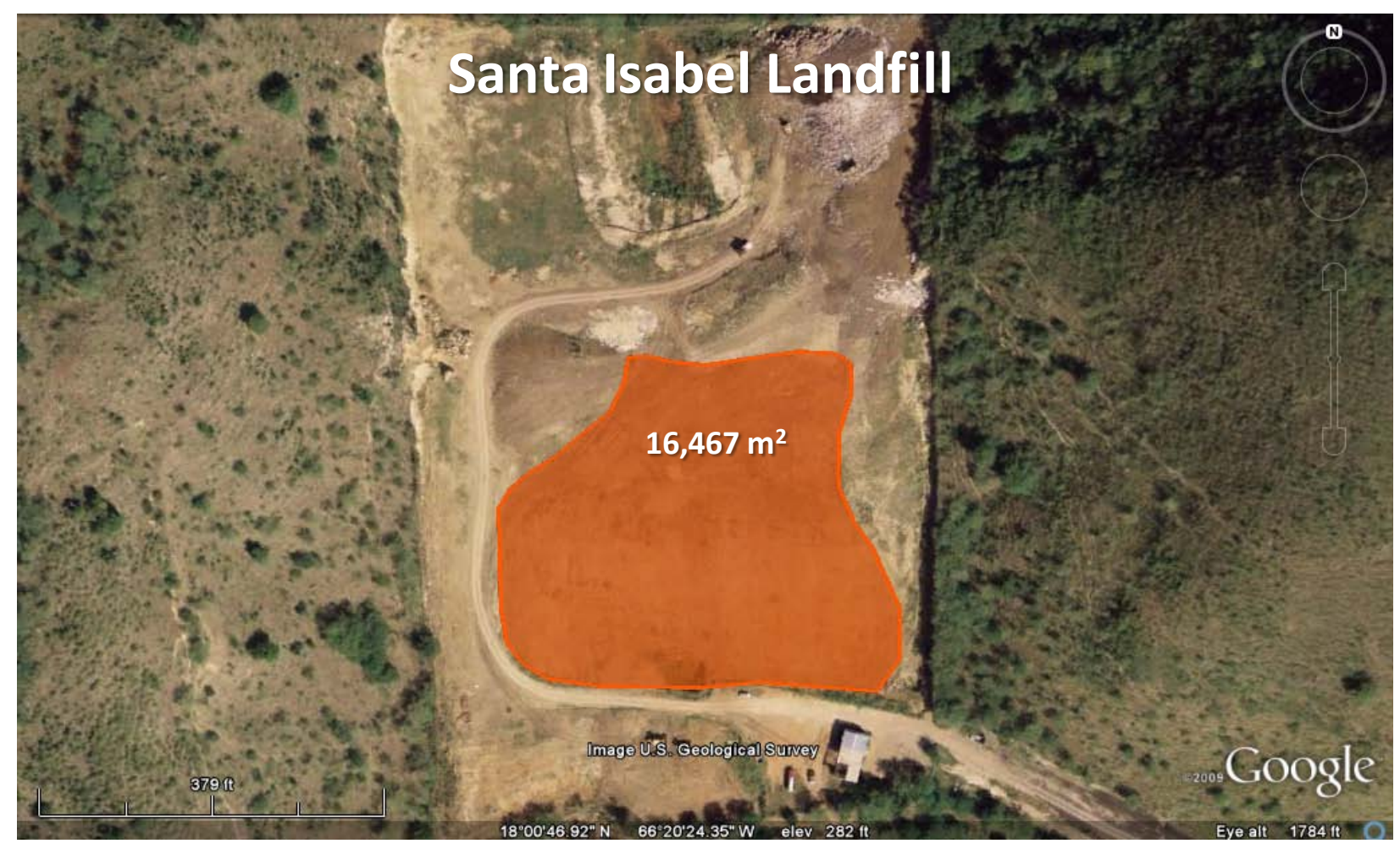

Figure 22. Aerial view of the feasible area for PV at the Santa Isabel Landfill

Credit: Google Earth 
Table 8. Santa Isabel Landfill Site PV System Options

\begin{tabular}{|c|c|c|c|c|c|c|c|c|}
\hline & & & & & \multirow{2}{*}{\multicolumn{2}{|c|}{$\begin{array}{c}\text { System Cost } \\
\text { Estimates with } \\
\text { Incentives (\$) }\end{array}$}} & \multirow{2}{*}{\multicolumn{2}{|c|}{$\begin{array}{l}\text { Simple Payback } \\
\text { Estimates (years) }\end{array}$}} \\
\hline & & & & & & & & \\
\hline $\begin{array}{c}\text { System } \\
\text { Type }\end{array}$ & $\begin{array}{l}\text { Potential } \\
\text { System } \\
\text { Size } \\
\text { (kW) }\end{array}$ & $\begin{array}{l}\text { Annual } \\
\text { Energy } \\
\text { Output } \\
\text { (kWh) }\end{array}$ & $\begin{array}{l}\text { Annual } \\
\text { Cost } \\
\text { Savings } \\
\text { (\$) }\end{array}$ & $\begin{array}{c}\text { Annual } \\
\text { O\&M }^{\mathrm{a}} \\
\text { (\$/year) }\end{array}$ & $\begin{array}{l}\text { Assuming } \\
\text { Lower } \\
\text { Cost }^{\text {b }}\end{array}$ & $\begin{array}{c}\text { Assuming } \\
\text { Higher } \\
\text { Cost }^{\mathrm{c}}\end{array}$ & $\begin{array}{c}\text { Assuming } \\
\text { Lower } \\
\text { Cost }^{\mathrm{b}}\end{array}$ & $\begin{array}{c}\text { Assuming } \\
\text { Higher } \\
\text { Cost }^{\mathrm{c}}\end{array}$ \\
\hline $\begin{array}{l}\text { Crystalline } \\
\text { Silicon- } \\
\text { Fixed Tilt }\end{array}$ & 600 & 961,200 & $\$ 124,956$ & $\$ 7,140$ & $\$ 1,370,000$ & $\$ 2,840,000$ & 11 & 24 \\
\hline $\begin{array}{l}\text { Crystalline } \\
\text { Silicon- } \\
\text { Single-axis } \\
\text { Tracking }\end{array}$ & 500 & 997,245 & $\$ 129,642$ & $\$ 17,500$ & $\$ 1,650,000$ & $\$ 3,400,000$ & 14 & 30 \\
\hline $\begin{array}{l}\text { Thin Film- } \\
\text { Fixed Tilt }\end{array}$ & 250 & 400,500 & $\$ 52,065$ & $\$ 2,720$ & $\$ 460,000$ & $\$ 1,020,000$ & 9 & 21 \\
\hline
\end{tabular}

${ }^{\mathrm{a}}$ Annual O\&M is based on the higher cost assumptions.

${ }^{\mathrm{b}} \$ 3.50 / \mathrm{W}$ is for a crystalline silicon fixed-tilt system. Single-axis tracking systems costs are assumed to be $\$ 5.00 / \mathrm{W}$ and thin-film systems are assumed to be $\$ 3.20 / \mathrm{W}$.

${ }^{c} \$ 7.00 / \mathrm{W}$ is for a crystalline silicon fixed-tilt system. Single-axis tracking systems costs are assumed to be $\$ 10.00 / \mathrm{W}$ and thin-film systems are assumed to be $\$ 6.40 / \mathrm{W}$.

\subsubsection{Toa Alta Landfill PV System}

The city of Toa Alta is located in the northern half of Puerto Rico and is approximately 8 miles from the north shore. The approximate population is currently 82,000. The Toa Alta Landfill is located to the south of the city just west of interstate PR-165 and is approximately 13 miles to the southwest of San Juan. The Toa Alta Landfill is not a particularly visible site as it is nestled in the hills. Figure 23 shows various views of the Toa Alta Landfill. 

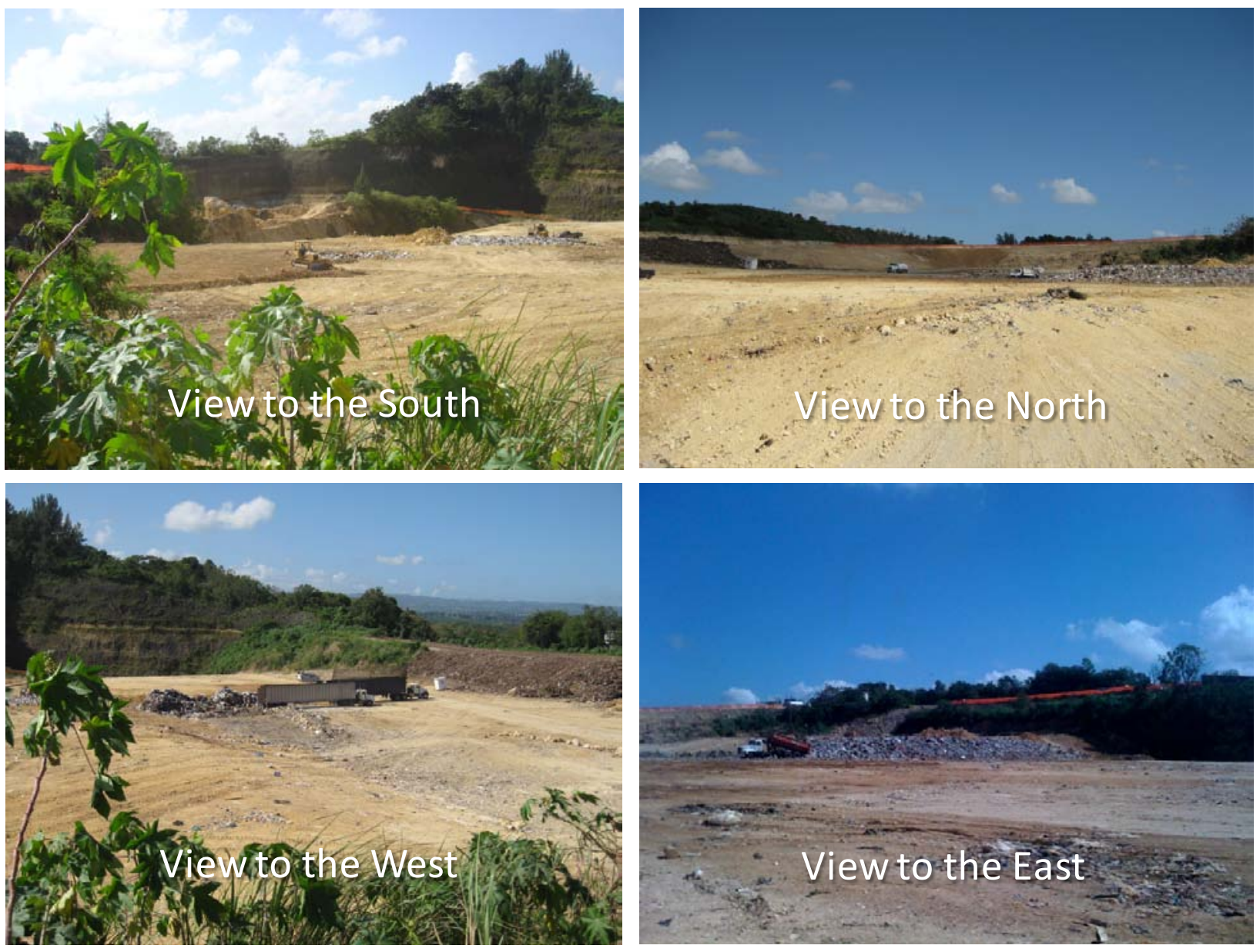

Figure 23. Views of the feasible area for PV at the Toa Alta Landfill

Credits: Philip Flax, EPA (south); Gail Mosey, NREL (north and west); Jimmy Salasovich, NREL (east)

As shown in Figure 23, there are large expanses of flat unshaded land. Although the Toa Alta Landfill was projected to close in 2007, it is still active. ${ }^{18}$ There are electrical points a relatively short distance away that a PV system could tie into. Construction could potentially be started on this site once the landfill is closed and capped. This site would need to have a ballast-mounted system implemented, as ground disturbances are not permitted.

The Toa Alta Landfill has the sixth largest available area for a PV system of the eight landfills that were assessed. The total feasible area for PV is $8,985 \mathrm{~m}^{2}$. Figure 24 shows the Toa Alta Landfill taken from Google Earth; the feasible area for PV is shaded in orange. As shown, there is one relatively large area at the Toa Alta Landfill that is feasible for PV. See Table 9 for the ground-mounted PV system possibilities for the Toa Alta Landfill. The three options outline the types of solar technology that could potentially be used. The economics of the potential systems were analyzed assuming that a PPA with PREPA would be used and PREPA would buy back at an electric rate of $\$ 0.13 / \mathrm{kWh}$. The cost of PV systems in Puerto Rico varies and therefore two cost estimates and associated simple paybacks are given.

\footnotetext{
${ }^{18}$ The projected closure date is based upon a study done in 2004 by Malcolm Pirnie Assoc. for the Puerto Rico Solid Waste Management Authority.
} 


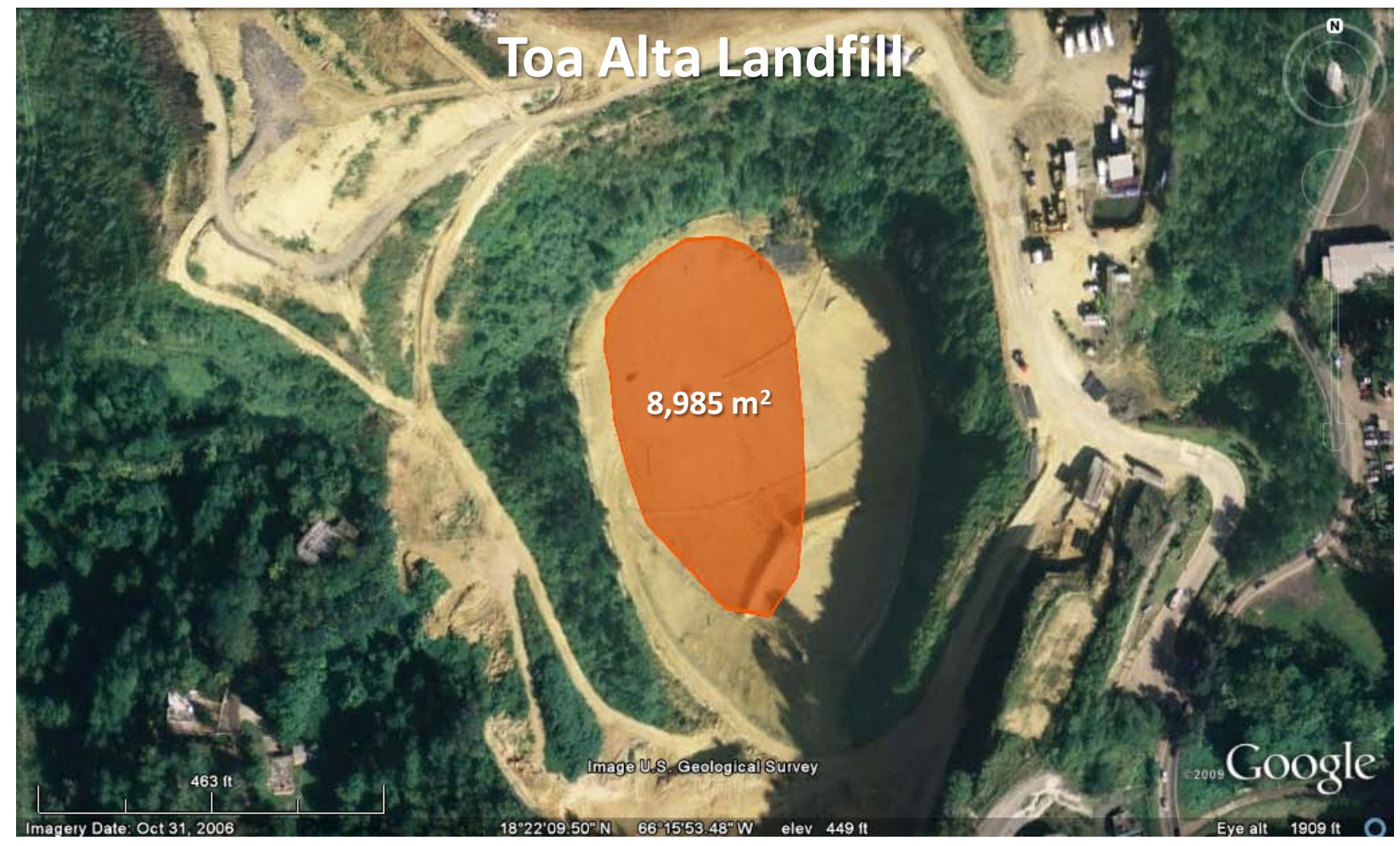

Figure 24. Aerial view of the feasible area for PV at the Toa Alta Landfill Credit: Google Earth 
Table 9. Toa Alta Landfill Site PV System Options

\begin{tabular}{|c|c|c|c|c|c|c|c|c|}
\hline \multirow[b]{2}{*}{$\begin{array}{l}\text { System } \\
\text { Type }\end{array}$} & \multirow[b]{2}{*}{$\begin{array}{l}\text { Potential } \\
\text { System } \\
\text { Size } \\
(\mathbf{k W})\end{array}$} & \multirow[b]{2}{*}{$\begin{array}{c}\text { Annual } \\
\text { Energy } \\
\text { Output } \\
\text { (kWh) }\end{array}$} & \multirow[b]{2}{*}{$\begin{array}{c}\text { Annual } \\
\text { Cost } \\
\text { Savings } \\
(\$)\end{array}$} & \multirow[b]{2}{*}{$\begin{array}{c}\text { Annual } \\
\text { O\&M } \\
\text { (\$/year) }\end{array}$} & \multicolumn{2}{|c|}{$\begin{array}{c}\text { System Cost } \\
\text { Estimates with } \\
\text { Incentives (\$) }\end{array}$} & \multicolumn{2}{|c|}{$\begin{array}{l}\text { Simple Payback } \\
\text { Estimates (years) }\end{array}$} \\
\hline & & & & & $\begin{array}{l}\text { Assuming } \\
\text { Lower } \\
\text { Cost }^{\mathrm{b}}\end{array}$ & $\begin{array}{c}\text { Assuming } \\
\text { Higher } \\
\text { Cost }^{c}\end{array}$ & $\begin{array}{c}\text { Assuming } \\
\text { Lower } \\
\text { Cost }^{\mathrm{b}}\end{array}$ & $\begin{array}{c}\text { Assuming } \\
\text { Higher } \\
\text { Cost }^{\mathrm{c}}\end{array}$ \\
\hline $\begin{array}{l}\text { Crystalline } \\
\text { Silicon- } \\
\text { Fixed Tilt }\end{array}$ & 350 & 560,700 & $\$ 72,891$ & $\$ 4,165$ & $\$ 757,500$ & $\$ 1,615,000$ & 11 & 23 \\
\hline $\begin{array}{l}\text { Crystalline } \\
\text { Silicon- } \\
\text { Single-axis } \\
\text { Tracking }\end{array}$ & 250 & 498,623 & $\$ 64,821$ & $\$ 8,750$ & $\$ 775,000$ & $\$ 1,650,000$ & 13 & 29 \\
\hline $\begin{array}{l}\text { Thin Film- } \\
\text { Fixed Tilt }\end{array}$ & 150 & 240,300 & $\$ 31,239$ & $\$ 1,632$ & $\$ 236,000$ & $\$ 572,000$ & 8 & 19 \\
\hline
\end{tabular}

${ }^{a}$ Annual O\&M is based on the higher cost assumptions.

${ }^{b} \$ 3.50 / \mathrm{W}$ is for a crystalline silicon fixed-tilt system. Single-axis tracking systems costs are assumed to be $\$ 5.00 / \mathrm{W}$ and thin-film systems are assumed to be $\$ 3.20 / \mathrm{W}$.

${ }^{c} \$ 7.00 / \mathrm{W}$ is for a crystalline silicon fixed-tilt system. Single-axis tracking systems costs are assumed to be $\$ 10.00 / \mathrm{W}$ and thin-film systems are assumed to be $\$ 6.40 / \mathrm{W}$.

\subsubsection{Toa Baja Landfill PV System}

Toa Baja is located on the north shore of Puerto Rico and is west of San Juan. The approximate population is currently 94,000. The Toa Baja Landfill is located to the southeast of the city just north of interstate PR-22. It is approximately 7 miles to the southwest of the city of San Juan, and it receives a lot of waste from the city of San Juan. The Toa Baja Landfill is not a particularly visible site as it is nestled in the hills. Figure 25 shows various views of the Toa Baja Landfill. 

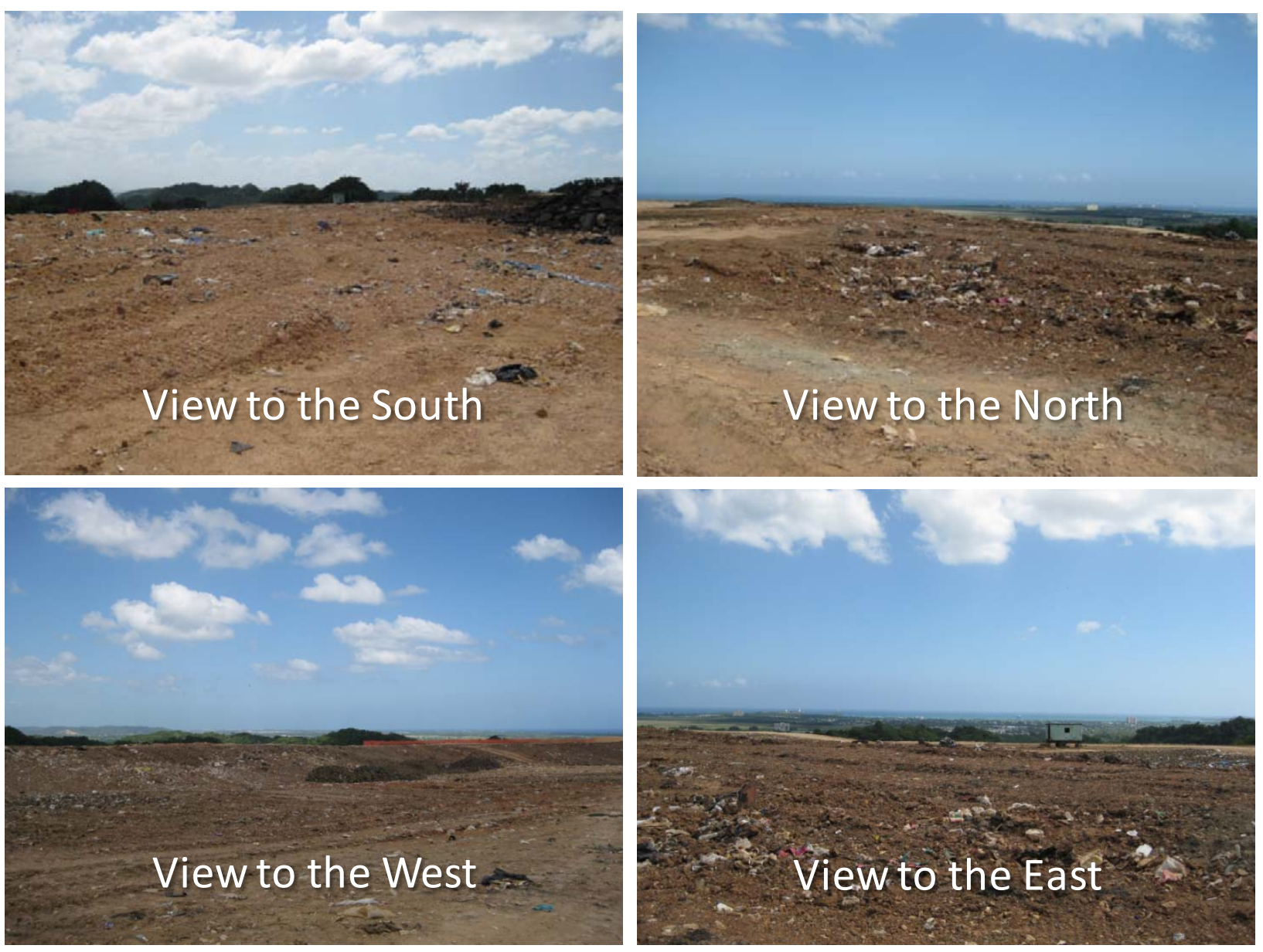

Figure 25. Views of the feasible area for PV at the Toa Baja Landfill

Credits: Gail Mosey, NREL

As shown in Figure 25, there are large expanses of flat unshaded land. The Toa Baja Landfill is not closed and capped, but it is scheduled to close in 2013. ${ }^{19}$ The prospect of installing a PV system on the Toa Baja Landfill could speed up the closure and capping process. There are electrical points a relatively short distance away that a PV system could tie into. Construction could potentially be started on this site immediately after the landfill is closed and capped. This site would need to have a ballast-mounted system implemented, as ground disturbances are not permitted. There is currently a methane monitoring system, and there is a possibility of a new cell opening at this site. A new $150 \mathrm{~kW}$ substation will be put in if a new cell is built, which would create another option for electrically tying in a PV system.

The Toa Baja Landfill has the third largest available area for a PV system of the eight landfills that were assessed. The total feasible area for PV is $20,849 \mathrm{~m}^{2}$. Figure 26 shows the Toa Baja Landfill taken from Google Earth; the feasible area for PV is shaded in orange. As shown, there is one relatively large area at the Toa Baja Landfill that is feasible for PV. See Table 10 for the ground-mounted PV system possibilities for the Toa Baja Landfill. The three options outline the

\footnotetext{
${ }^{19}$ The projected closure date is based upon a study done in 2004 by Malcolm Pirnie Assoc. for the Puerto Rico Solid Waste Management Authority.
} 
types of solar technology that could potentially be used. The economics of the potential systems were analyzed assuming that a PPA with PREPA would be used and PREPA would buy back at an electric rate of $\$ 0.13 / \mathrm{kWh}$. The cost of PV systems in Puerto Rico varies and therefore two cost estimates and associated simple paybacks are given.

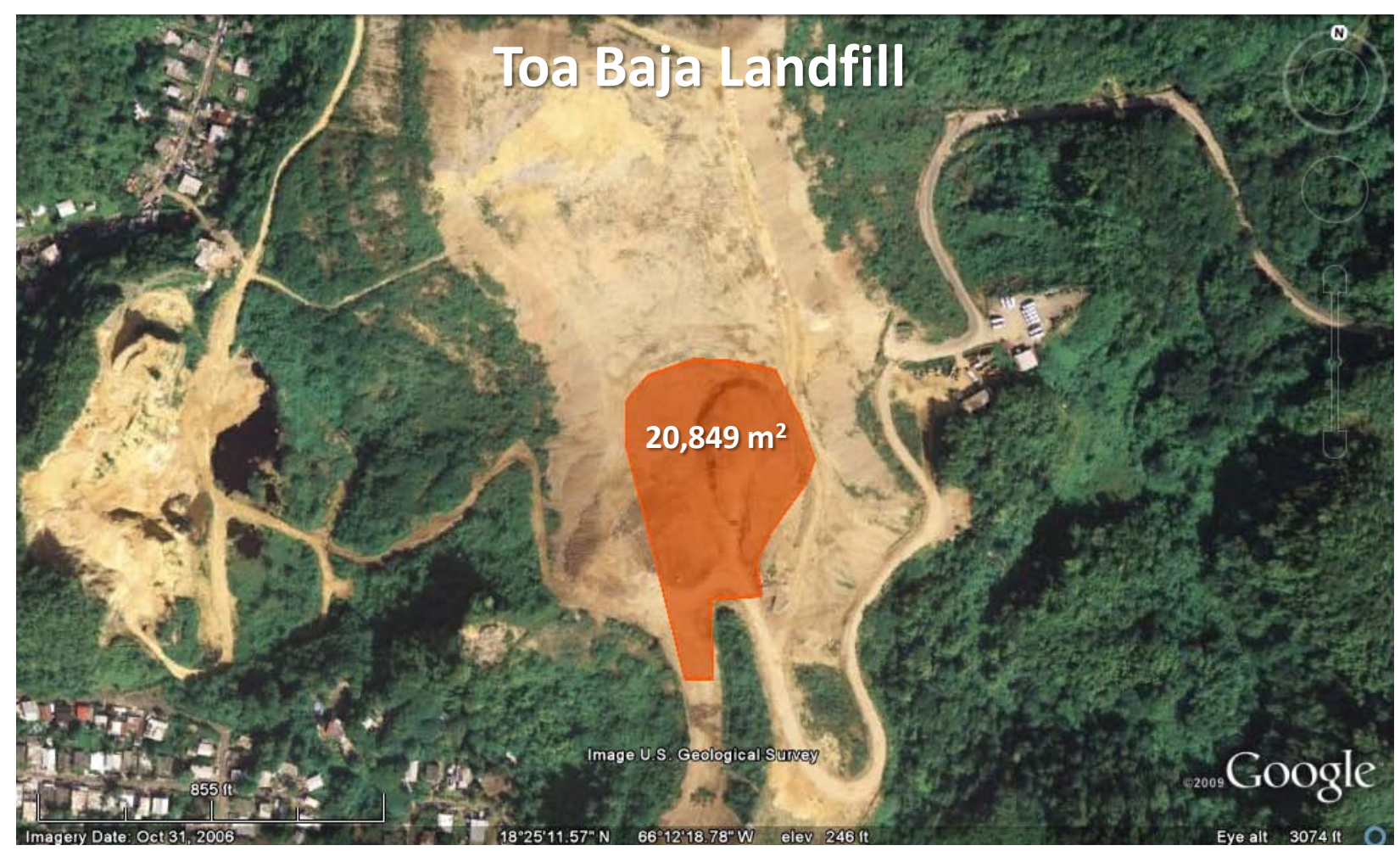

Figure 26. Aerial view of the feasible area for PV at the Toa Baja Landfill

Credit: Google Earth 
Table 10. Toa Baja Landfill Site PV System Options

\begin{tabular}{|c|c|c|c|c|c|c|c|c|}
\hline \multirow[b]{2}{*}{$\begin{array}{l}\text { System } \\
\text { Type }\end{array}$} & \multirow[b]{2}{*}{$\begin{array}{c}\text { Potential } \\
\text { System } \\
\text { Size } \\
(\mathbf{k W})\end{array}$} & \multirow[b]{2}{*}{$\begin{array}{c}\text { Annual } \\
\text { Energy } \\
\text { Output } \\
\text { (kWh) }\end{array}$} & \multirow[b]{2}{*}{$\begin{array}{c}\text { Annual } \\
\text { Cost } \\
\text { Savings } \\
(\$)\end{array}$} & \multirow[b]{2}{*}{$\begin{array}{c}\text { Annual } \\
\text { O\&M } \\
\text { (\$/year) }\end{array}$} & \multicolumn{2}{|c|}{$\begin{array}{l}\text { System Cost } \\
\text { Estimates with } \\
\text { Incentives (\$) }\end{array}$} & \multicolumn{2}{|c|}{$\begin{array}{l}\text { Simple Payback } \\
\text { Estimates (years) }\end{array}$} \\
\hline & & & & & $\begin{array}{c}\text { Assuming } \\
\text { Lower } \\
\text { Cost }^{\text {b }}\end{array}$ & $\begin{array}{c}\text { Assuming } \\
\text { Higher }^{c} \\
\text { Cost }^{c}\end{array}$ & $\begin{array}{l}\text { Assuming } \\
\text { Lower }^{\text {Cost }}\end{array}$ & $\begin{array}{c}\text { Assuming } \\
\text { Higher } \\
\text { Cost }^{c}\end{array}$ \\
\hline $\begin{array}{l}\text { Crystalline } \\
\text { Silicon- } \\
\text { Fixed Tilt }\end{array}$ & 500 & 801,000 & $\$ 104,130$ & $\$ 5,950$ & $\$ 1,125,000$ & $\$ 2,350,000$ & 11 & 24 \\
\hline $\begin{array}{l}\text { Crystalline } \\
\text { Silicon- } \\
\text { Single-axis } \\
\text { Tracking }\end{array}$ & 650 & $1,296,419$ & $\$ 168,534$ & $\$ 22,750$ & $\$ 2,175,000$ & $\$ 4,450,000$ & 14 & 31 \\
\hline $\begin{array}{l}\text { Thin Film- } \\
\text { Fixed Tilt }\end{array}$ & 350 & 560,700 & $\$ 72,891$ & $\$ 3,808$ & $\$ 684,000$ & $\$ 1,468,000$ & 10 & 21 \\
\hline
\end{tabular}

${ }^{\mathrm{a}}$ Annual O\&M is based on the higher cost assumptions.

${ }^{\mathrm{b}} \$ 3.50 / \mathrm{W}$ is for a crystalline silicon fixed-tilt system. Single-axis tracking systems costs are assumed to be $\$ 5.00 / \mathrm{W}$ and thin-film systems are assumed to be $\$ 3.20 / \mathrm{W}$.

${ }^{c} \$ 7.00 / \mathrm{W}$ is for a crystalline silicon fixed-tilt system. Single-axis tracking systems costs are assumed to be $\$ 10.00 / \mathrm{W}$ and thin-film systems are assumed to be $\$ 6.40 / \mathrm{W}$.

\subsubsection{Summary of All Sites}

Eight landfills in Puerto Rico were considered, and seven of the eight landfills were found to be suitable for PV systems. Figure 27 shows a comparison of the landfills in Puerto Rico that were visited; the X-mark over Salinas indicates that it was too sloped to be feasible for solar PV. The landfills are all at the same scale so that the relative size can be visualized. The economics of the potential systems were analyzed assuming that a PPA with PREPA would be used and PREPA would buy back the electricity at an electric rate of $\$ 0.13 / \mathrm{kWh}$. 
Table 11 summarizes the system performance and economics of a potential system that would use all feasible landfill areas that were surveyed in Puerto Rico. All sites do not need to be developed in one project; beginning with a smaller demonstration system and increasing capacity as funds become available may be a better approach. Calculations for this analysis assume the $30 \%$ federal tax credit incentive would be captured for the system.

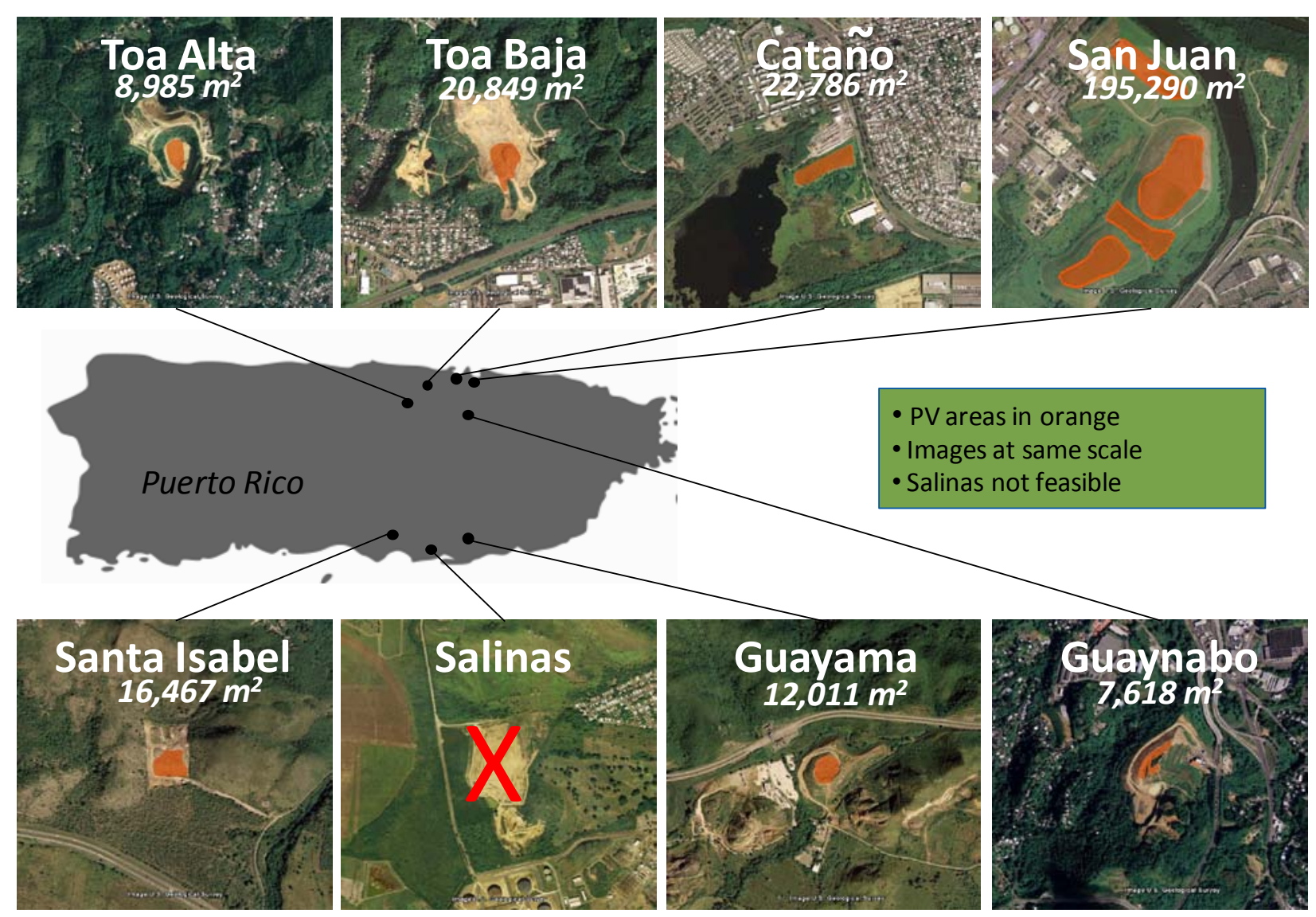

Figure 27. Comparison of the feasible areas for PV at landfills in Puerto Rico

Credits: Google Earth 
Table 11. PV System Performance and Economics by System Type ${ }^{a}$

\begin{tabular}{|c|c|c|c|c|c|c|c|c|}
\hline \multirow[b]{2}{*}{$\begin{array}{c}\text { PV } \\
\text { System } \\
\text { Size } \\
(\mathbf{k W})\end{array}$} & \multirow[b]{2}{*}{$\begin{array}{c}\text { Annual } \\
\text { Output } \\
\text { (kWh/year) }\end{array}$} & \multirow[b]{2}{*}{$\begin{array}{l}\text { Number } \\
\text { of Houses } \\
\text { Powered }^{b}\end{array}$} & \multirow[b]{2}{*}{$\begin{array}{l}\text { Annual } \\
\text { Cost } \\
\text { Savings } \\
\text { (\$/year) }\end{array}$} & \multirow[b]{2}{*}{$\begin{array}{c}\text { Annual } \\
\text { O\&Mc } \\
\text { (\$/year) }\end{array}$} & \multicolumn{2}{|c|}{$\begin{array}{l}\text { System Cost Estimates } \\
\text { with Incentives (\$) }\end{array}$} & \multicolumn{2}{|c|}{$\begin{array}{l}\text { Simple Payback } \\
\text { Estimates (years) }\end{array}$} \\
\hline & & & & & $\begin{array}{l}\text { Assuming } \\
\text { Lower } \\
\text { Cost }^{\mathrm{d}}\end{array}$ & $\begin{array}{l}\text { Assuming } \\
\text { Higher } \\
\text { Cost }^{\mathrm{e}}\end{array}$ & $\begin{array}{l}\text { Assuming } \\
\text { Lower } \\
\text { Cost }^{\mathrm{d}}\end{array}$ & $\begin{array}{c}\text { Assuming } \\
\text { Higher } \\
\text { Cost }^{\mathrm{e}}\end{array}$ \\
\hline \multicolumn{9}{|c|}{ Crystalline Silicon (Fixed Tilt $18.4^{\circ}$ ) } \\
\hline $\begin{array}{c}10,55 \\
0\end{array}$ & $16,901,100$ & 1,531 & $\$ 2,197,143$ & $\$ 125,545$ & $\$ 25,147,500$ & $\$ 50,995,000$ & 12 & 25 \\
\hline \multicolumn{9}{|c|}{ Crystalline Silicon (Single-axis Tracking) } \\
\hline 8,900 & $17,750,961$ & 1,608 & $\$ 2,307,625$ & $\$ 311,500$ & $\$ 30,450,000$ & $\$ 61,600,000$ & 14 & 31 \\
\hline \multicolumn{9}{|c|}{ Thin Film (Fixed Tilt $18.4^{\circ}$ ) } \\
\hline 4,600 & $7,369,200$ & 668 & $\$ 957,996$ & $\$ 50,048$ & $\$ 9,604,000$ & $\$ 19,908,000$ & 10 & 22 \\
\hline
\end{tabular}

${ }^{a}$ Data assume a maximum usable area of all feasible landfills of $284,006 \mathrm{~m}^{2}$.

${ }^{\mathrm{b}}$ Number of average American households that could hypothetically be powered by the PV system assuming $11,040 \mathrm{kWh} /$ year/household. ${ }^{20}$

${ }^{c}$ Annual O\&M is based on the higher cost assumptions.

${ }^{d} \$ 3.50 / \mathrm{W}$ is for a crystalline silicon fixed-tilt system. Single-axis tracking systems costs are assumed to be $\$ 5.00 / \mathrm{W}$ and thin-film systems are assumed to be $\$ 3.20 / \mathrm{W}$.

${ }^{\mathrm{e}} \$ 7.00 / \mathrm{W}$ is for a crystalline silicon fixed-tilt system. Single-axis tracking systems costs are assumed to be $\$ 10.00 / \mathrm{W}$ and thin-film systems are assumed to be $\$ 6.40 / \mathrm{W}$.

${ }^{20}$ U.S. Energy Information Administration. http://www.eia.doe.gov/ask/electricity faqs.asp\#electricity use home. Accessed October 22, 2010. 


\section{Economics and Performance}

\subsection{Assumptions and Input Data for Analysis}

The viability of PV depends greatly on the local electricity rate. According to the most recent annual report ${ }^{21}$ published in June 2009 by PREPA, the electric utility serving Puerto Rico, average residential electric rates were $\$ 0.2158 / \mathrm{kWh}$, average commercial rates were $\$ 0.2232 / \mathrm{kWh}$, and average industrial rates were $\$ 0.1831 / \mathrm{kWh}$. These electric rates are similar to those found in the Hawaiian Islands, and they are roughly double the average electric rate in the Unites States. The net-metering laws in Puerto Rico state that whatever the PV electric output above the customer use, PREPA will buy $75 \%$ of that at either the avoided fuel cost or $\$ 0.10 / \mathrm{kWh}$, whichever is greater. The avoided fuel cost is in the range of $\$ 0.10 / \mathrm{kWh}$ or lower so $\$ 0.10 / \mathrm{kWh}$ was assumed. The PV system size limit for net metering is $25 \mathrm{~kW}$ for residential and $1 \mathrm{MW}$ for commercial.

There is little to no electricity use at a closed landfill and all of the electricity generated by a proposed PV system is assumed to be sold back to the utility. From an economic standpoint, the current net-metering laws in Puerto Rico are not advantageous for PV systems that generate large amounts of excess energy because of the relatively low buyback rate of $75 \%$ of $\$ 0.10 / \mathrm{kWh}$. Setting up a PPA where PREPA would agree to buy back the power at a higher rate would be much more beneficial. There are currently two large-scale PV projects in Puerto Rico that were both started in 2010 that use a PPA. The first project ${ }^{22}$ is a 20 MW PV system in Guayama where AES Ilumina entered a PPA with PREPA where PREPA agreed to buy the electricity at a rate of $\$ 0.13 / \mathrm{kWh}$. The second project ${ }^{23}$ is a $63 \mathrm{MW}$ PV system in Salinas where the CIRO One Group entered a PPA with PREPA but the buyback rate has yet to be established.

The economics of the potential systems were analyzed assuming that a PPA with PREPA would be used and PREPA would buy back the electricity at an electric rate of $\$ 0.13 / \mathrm{kWh}$. Incentives offered by the federal government, the Commonwealth of Puerto Rico, and by PREPA were assumed in this analysis.

The cost of PV systems in Puerto Rico varies and therefore two cost estimates were used. The first estimate is in the low range of current installed costs of PV systems and is based on costs of the $20 \mathrm{MW}$ system that is currently being installed in Guayama by AES Ilumina. The second estimate is in the higher range of current installed costs of PV systems and is based on past costs of smaller scale systems. The low-range installed cost for fixed-tilt ground-mounted systems was assumed to be $\$ 3.50 / \mathrm{W}$ for crystalline silicon and $\$ 3.20 / \mathrm{W}$ for thin film. The low-range installed cost for single-axis tracking systems was assumed to be $\$ 5.00 / \mathrm{W}$ for crystalline silicon. It was assumed that the low-range installed cost of fixed-tilt roof-mounted systems would be $\$ 6.00 / \mathrm{W}$ for crystalline silicon and $\$ 5.40 / \mathrm{W}$ for thin film. The high-range installed cost for fixed-tilt ground-mounted systems was assumed to be $\$ 7.00 / \mathrm{W}$ for crystalline silicon and

\footnotetext{
${ }^{21}$ Thirty-Sixth Annual Report on the Electricity Property of the Puerto Rico Electric Power Authority. http://www.aeepr.com/INVESTORS/Financial\%20Information/Annual\%20Reports/ConsEng_36th_Rpt_2009\%20A nnual\%20Report\%20Final.pdf. Accessed December 8, 2010.

${ }^{22}$ All Business. "Solar Power Project." http://www.allbusiness.com/energy-utilities/utilities-industry-electric-powerpower/14753424-1.html. Accessed December 8, 2010.

${ }^{23}$ Marino, J. "Work to Start on 63 MW Solar Plant in Salinas." Caribbean Business. http://www.caribbeanbusinesspr.com/news03.php?nt_id=49337\&ct_id=1. Accessed December 8, 2010.
} 
$\$ 6.40 / \mathrm{W}$ for thin film. The high-range installed cost for single-axis tracking systems was assumed to be $\$ 10.00 / \mathrm{W}$ for crystalline silicon. It was assumed that the high-range installed cost of fixed-tilt roof-mounted systems would be $\$ 9.33 / \mathrm{W}$ for crystalline silicon and $\$ 8.73 / \mathrm{W}$ for thin film. These prices include the PV array and the balance-of-system components for each system, including the inverter, electrical equipment, and installation. The economics of grid-tied PV depend on incentives, the cost of electricity, and the solar resource including panel tilt and orientation.

A system DC to AC conversion of $77 \%$ was assumed. This includes losses in the inverter, wire losses, PV module losses, and losses due to temperature effects. PVWATTS was used to calculate energy performance.

It was assumed for this analysis that federal and state incentives are received. Identifying and leveraging state incentives and grants is an important part of making PV systems cost effective. A private, tax-paying entity that owns PV systems can qualify for a $30 \%$ federal business energy investment tax credit (ITC) and accelerated depreciation on the PV system, which are worth about $15 \%$. The total potential tax benefits to the tax-paying entity are about $45 \%$ of the system cost. Alternatively, the tax-paying entity can opt to receive a cash payment of up to $30 \%$ of eligible project costs from the U.S. Department of Treasury Section 1603 program $^{24}$ once the eligible system is in service. The American Reinvestment and Recovery Act of 2009 (Recovery Act) allows for this cash payment in lieu of the ITC. To receive the payment from the Treasury, construction of the property must begin no later than December 31, 2010. Because the federal government does not pay taxes, private ownership of the PV system is required to capture tax incentives or Section 1603 grant payments. ${ }^{25}$ Municipalities are not tax-paying entities and therefore would have to pursue a PPA in order to get the $30 \%$ federal tax credit, which is described in the following section.

\subsection{Incentives and Financing Opportunities}

The Database of State Incentives for Renewables and Efficiency (DSIRE) provides a summary of net metering, interconnection rules, and other incentives available to Puerto Rico utility customers. The power from these systems could be sold to PREPA, the utility for Puerto Rico.

Renewable energy systems, including commercial solar PV, are subject to interconnection rules promulgated at the state level. Interconnection rules for Puerto Rico were found on the DSIRE Web site. PREPA adopted interconnection standards in 2007 that are based on the interconnections standards established in the federal Energy Policy Act of 2005. This requires all interconnected systems to comply with the safety and performance requirements put forth in the IEEE Standard 1547 as well as local construction and safety standards ${ }^{26}$.

State incentives are currently offered for commercial solar power systems in Puerto Rico for $\$ 4 / \mathrm{DC}$-Watt for up to $50 \%$ of the project costs or $\$ 100,000$, whichever is lower. State incentives of $\$ 8 / \mathrm{DC}$-Watt up to $\$ 100,000$ are offered for governmental systems. State incentives of \$4/DC-

\footnotetext{
${ }^{24}$ This program was codified in Section 1603 of the American Recovery and Reinvestment Act of 2009.

${ }^{25}$ DSIRE. "Puerto Rico." http://www.dsireusa.org/incentives/incentive.cfm?Incentive Code=PR14F\&re=1\&ee=1. Accessed September 2010.

${ }^{26}$ DSIRE. "Puerto Rico." http://www.dsireusa.org/incentives/incentive.cfm? Incentive_Code=PR14F\&re=1\&ee=1. Accessed September 2010.
} 
Watt up to $\$ 15,000$ are offered for residential systems. The $30 \%$ tax credit federal incentive can be captured if the system is owned by a tax-paying entity.

The system facilitator could potentially pursue an agreement with PREPA that would negotiate both a higher price for the electricity produced by the potential system and the potential to sell renewable energy credits (RECs). Any power that is produced by a solar PV system will help the state reach its renewable portfolio standard (RPS) and would be a major opportunity for PREPA to accelerate the diversification of their energy mix with clean energy. It has been demonstrated across the country that people are willing to pay a premium for certified clean energy, ${ }^{27}$ and PREPA could start a voluntary green power purchase pilot program with energy from the landfills in Puerto Rico. ${ }^{28}$

Technical assistance to support project development is available through the U.S. Department of Energy (DOE) and the Office of Energy Efficiency and Renewable Energy (EERE). The activity provides technical assistance to commercial power developers, technology projects involving liquid fuels developed from biomass, and information to the public on renewable energy applications. The DOE Office of EERE can assist commercial wind and solar developers by providing detailed renewable resource maps, interfacing with Puerto Rico utilities, and contacting local economic developers.

There are several options for financing a solar PV system. However, obtaining investment from landowners with little on-site presence - such as is the case with the landfills in Puerto Ricocan be difficult. A potential alternative financing option is the third-party ownership PPA. The agreement works by having a solar contractor install, finance, and operate the system while the utility company purchases the electricity generated by the system. The system is financed by the solar contractor, and the payments are paid by the electricity and RECs that are sold to the utility. In this configuration, the land that the solar system is on would need to be leased to the owner of the system for the duration of the contract.

Another gap financing tools that may be available is tax increment financing (TIF). Connecticut, Iowa, Michigan, and Wisconsin have been leaders in structuring state-facilitated TIF financing as an effective and efficient means to enhance site reuse and redevelopment programs and to obtain successful cleanup and redevelopment results. Municipalities are good candidates for TIF because it is an incentive they can implement under their own control. A full list of incentives can be found in Appendix B.

\subsection{Job Creation}

The implementation of this project would represent a large amount of money entering the clean energy industry of Puerto Rico. The Council of Economic Advisors (CEA) calculated the number of jobs (direct, indirect, and induced) created due to federal spending using economic models developed with real world data. CEA found that $\$ 92,000$ in federal spending is

\footnotetext{
${ }^{27}$ Transmission \& Distribution World. "NREL Highlights Utility Green Power Leaders." http://tdworld.com/customer service/doe-nrel-utility-green-power-0409/. Accessed July 20, 2100.

${ }^{28}$ An example of such a program is Xcel Energy's Windsource program. For more information, see http://www .xcelenergy.com/Colorado/Company/Environment/Renewable\%20Energy/Pages/Wind Power.aspx. For detailed information about federal, state, and local incentives in Puerto Rico, see http://www.dsireusa.org/incentives/incentive.cfm?Incentive_Code=PR14F\&re=1\&ee=1.
} 
equivalent to one job-year. This means that for every $\$ 92,000$ of federal money that is spent, there is one job created that can be sustained for one year. See Table 12 and Table 13 for an estimate of job creation by system type if all seven landfills in Puerto Rico were used for solar $\mathrm{PV}$. This project represents a large amount of money that would create a significant number of jobs. A portion of these jobs, including the installation and system maintenance jobs, will be created within the community. The jobs created column refers to the number of job-years that would be created as a result of the one-time project capital investment. This means that the jobs will be created and sustained for one year. The jobs sustained column refers to the number of jobs that would be sustained as a result of the O\&M of the system. These jobs will be sustained for the life of the system, due to the annual cost to keep the system operating.

Table 12. Estimated Job Creation by PV System Type Assuming Lower Installed Costs ${ }^{a}$

\begin{tabular}{lcc}
\hline System Type & $\begin{array}{l}\text { Jobs Created } \\
\text { (job years) }\end{array}$ & $\begin{array}{c}\text { Jobs Sustained }^{\mathbf{c}} \\
\text { (number of jobs) }\end{array}$ \\
\cline { 2 - 3 } Crystalline Silicon (Fixed Tilt) & 273 & 0 \\
Crystalline Silicon (Single-axis Tracking) & 331 & 1 \\
Thin Film (Fixed Tilt) & 104 & 0
\end{tabular}

a $\$ 3.50 / \mathrm{W}$ is for a crystalline silicon fixed-tilt system. Single-axis tracking systems costs are assumed to be $\$ 5.00 / \mathrm{W}$ and thin-film systems are assumed to be $\$ 3.20 / \mathrm{W}$.

${ }^{\mathrm{b}}$ Job-years created as a result of project capital investment including direct, indirect, and induced jobs.

c Jobs (direct, indirect, and induced) sustained as a result of O\&M of the system.

Table 13. Estimated Job Creation by PV System Type Assuming Higher Installed Costs ${ }^{\mathrm{a}}$

\begin{tabular}{lcc}
\hline System Type & $\begin{array}{l}\text { Jobs Created } \\
\text { (job years) }\end{array}$ & $\begin{array}{l}\text { Jobs Sustained }^{\text {c }} \\
\text { (number of jobs) }^{\text {(numb }}\end{array}$ \\
\cline { 2 - 3 } Crystalline Silicon (Fixed Tilt) & 554 & 1 \\
Crystalline Silicon (Single-axis Tracking) & 670 & 3 \\
Thin Film (Fixed Tilt) & 216 & 0 \\
\hline
\end{tabular}

a $\$ 7.00 / \mathrm{W}$ is for a crystalline silicon fixed-tilt system. Single-axis tracking systems costs are assumed to be $\$ 10.00 / \mathrm{W}$ and thin-film systems are assumed to be $\$ 6.40 / \mathrm{W}$.

${ }^{\mathrm{b}}$ Job-years created as a result of project capital investment including direct, indirect, and induced jobs.

${ }^{c}$ Jobs (direct, indirect, and induced) sustained as a result of O\&M of the system. 


\section{Hypothetical Electric Rate Increases}

The economics of a potential PV system on landfills in Puerto Rico depend greatly on the cost of electricity and at what rate the utility will buy back the excess electricity. Currently, PREPA has entered a PPA where they agreed to buy back the electricity generated by a PV system at an electric rate of $\$ 0.13 / \mathrm{kWh}$. This rate could hypothetically increase to $\$ 0.15 / \mathrm{kWh}$ or higher in a relatively short amount of time. A rate increase of this magnitude would further improve the economics of a solar PV generation plant. See Table 14 for a summary of the system economics assuming a hypothetical buyback electric rate increase to $\$ 0.15 / \mathrm{kWh}$.

Table 14. PV System Performance and Economics Assuming Lower Installed Costs ${ }^{a}$ and with a Hypothetical Rate Increase to $\$ 0.15 / \mathrm{kWh}^{\mathrm{b}}$

\begin{tabular}{|c|c|c|c|c|c|c|}
\hline $\begin{array}{c}\text { Array Tilt } \\
\text { (Deg) }\end{array}$ & $\begin{array}{l}\text { PV System } \\
\text { Size (kW) }\end{array}$ & $\begin{array}{c}\text { Annual } \\
\text { Output } \\
\text { (kWh/year) }\end{array}$ & $\begin{array}{l}\text { Annual } \\
\text { Cost } \\
\text { Savings } \\
\text { (\$/year) }\end{array}$ & $\begin{array}{c}\text { Annual } \\
\text { O\&M } \\
\text { (\$/year) }\end{array}$ & $\begin{array}{l}\text { System } \\
\text { Cost with } \\
\text { Incentives } \\
\text { (\$) }\end{array}$ & $\begin{array}{l}\text { Payback } \\
\text { Period with } \\
\text { Incentive } \\
\text { (years) }\end{array}$ \\
\hline \multicolumn{7}{|c|}{ Crystalline Silicon (Fixed Tilt) } \\
\hline 18.4 & 10,550 & $16,901,100$ & $\$ 2,535,165$ & $\$ 62,773$ & $\$ 25,147,500$ & 10 \\
\hline \multicolumn{7}{|c|}{ Crystalline Silicon (Single-axis Tracking) } \\
\hline 0 & 8,900 & $17,750,961$ & $\$ 2,662,664$ & $\$ 155,750$ & $\$ 30,450,000$ & 12 \\
\hline \multicolumn{7}{|c|}{ Thin Film (Fixed Tilt) } \\
\hline 18.4 & 4,600 & $7,369,200$ & $\$ 1,105,380$ & $\$ 25,024$ & $\$ 9,604,000$ & 9 \\
\hline
\end{tabular}

Table 15. PV System Performance and Economics Assuming Higher Installed Costs ${ }^{\mathrm{a}}$ and with a Hypothetical Rate Increase to $\$ 0.15 / \mathrm{kWh}^{\mathrm{b}}$

\begin{tabular}{|c|c|c|c|c|c|c|}
\hline $\begin{array}{c}\text { Array Tilt } \\
\text { (Deg) }\end{array}$ & $\begin{array}{l}\text { PV System } \\
\text { Size (kW) }\end{array}$ & $\begin{array}{c}\text { Annual } \\
\text { Output } \\
\text { (kWh/year) }\end{array}$ & $\begin{array}{c}\text { Annual } \\
\text { Cost } \\
\text { Savings } \\
\text { (\$/year) }\end{array}$ & $\begin{array}{c}\text { Annual } \\
\text { O\&M } \\
\text { (\$/year) }\end{array}$ & $\begin{array}{c}\text { System } \\
\text { Cost with } \\
\text { Incentives } \\
(\$)\end{array}$ & $\begin{array}{c}\text { Payback } \\
\text { Period with } \\
\text { Incentive } \\
\text { (years) }\end{array}$ \\
\hline \multicolumn{7}{|c|}{ Crystalline Silicon (Fixed Tilt) } \\
\hline 18.4 & 10,550 & $16,901,100$ & $\$ 2,535,165$ & $\$ 125,545$ & $\$ 50,995,000$ & 21 \\
\hline \multicolumn{7}{|c|}{ Crystalline Silicon (Single-axis Tracking) } \\
\hline 0 & 8,900 & $17,750,961$ & $\$ 2,662,664$ & $\$ 311,500$ & $\$ 61,600,000$ & 26 \\
\hline \multicolumn{7}{|c|}{ Thin Film (Fixed Tilt) } \\
\hline 18.4 & 4,600 & $7,369,200$ & $\$ 1,105,380$ & $\$ 50,048$ & $\$ 19,908,000$ & 19 \\
\hline
\end{tabular}




\section{Conclusions and Recommendations}

The landfills considered in this report are all feasible areas in which to implement solar PV systems with the exception of the Salinas Landfill, which is too hilly to install PV. Using obtainable and accessible land that is unavailable for other purposes allows for reuse of land that would not otherwise contribute to productivity for Puerto Rico. Installing a solar generation plant and the associated facilities on landfills relieves "greenfields" of land-use impacts. Developing solar facilities on landfills can provide an economically viable reuse option for landfills in Puerto Rico. The landfills have existing transmission capacity, roads, industrial zoning, and all other critical infrastructure in place for PV systems. One obstacle to PV on landfills is that landfills require little to no electricity once they are capped and closed. Therefore, finding a use for the electricity generated by the PV system is a key element.

It is recommended that the party ultimately responsible for facilitating the implementation of PV systems contact PREPA and attempt to set up an agreement in which PREPA would purchase the electricity generated at the sites studied. According to the site production calculations, the most cost-effective system in terms of return on investment is the thin-film fixed-tilt technology. The lower cost of the system combined with the ample land available makes a thin-film system a good fit for these sites. Thin-film technology is a proven technology that can be successfully implemented with a ballasted-style mounting system. Crystalline silicon system styles - both fixed-tilt and single-axis tracking systems - could also be implemented, but the increased cost of the crystalline silicon panels may extend the payback period.

For this feasibility study, system calculations and sizes were based on site area; however, actual system installation should be based on the availability of funds or on the amount of power that can be sold. Installing a small demonstration system and adding capacity as funding becomes available might make sense. When the system goes out to bid, a design-build contract should be issued that requests the best performance ( $\mathrm{kWh} /$ year) at the best price and that allows vendors to optimize system configuration, including slope. A third-party ownership PPA provides the most feasible way for a system to be financed on these sites. All payback calculations assumed that the $30 \%$ federal tax credit would be captured for the systems.

In the coming years, increasing electrical rates and increased necessity for clean power will continue to improve the feasibility of implementing solar PV systems at these sites. 


\section{Appendix A. Assumptions for Calculations ${ }^{29}$}

Table A-1. Assumptions for Calculations for Ground-mounted PV Systems Assuming \$3.50/W for Crystalline Silicon Fixed-tilt Systems, $\$ 5.00 / W$ for Single-axis Tracking Systems, and $\$ 3.20 / \mathrm{W}$ for Thin-film Fixed-tilt Systems

\begin{tabular}{|c|c|c|c|c|c|c|c|c|}
\hline Location & $\begin{array}{l}\text { Array Tilt } \\
\text { (Deg) }\end{array}$ & $\begin{array}{l}\text { Max Usable Area } \\
\left(\mathrm{ft}^{2}\right)\end{array}$ & $\begin{array}{l}\text { Rounded PV System } \\
\text { Size (kW) }\end{array}$ & $\begin{array}{l}\text { Annual Output } \\
\text { (kWh/year) }\end{array}$ & $\begin{array}{l}\text { Annual Cost Savings } \\
\text { (\$/year) }\end{array}$ & $\begin{array}{l}\text { Annual O\&M } \\
\text { (\$/year) }\end{array}$ & $\begin{array}{l}\text { System Cost with } \\
\text { Incentives (\$) }\end{array}$ & $\begin{array}{l}\text { Payback Period } \\
\text { (years) }\end{array}$ \\
\hline \multicolumn{9}{|c|}{ Crystalline Silicon (Fixed Tilt) } \\
\hline Cataño & 18.4 & 220,738 & 850 & $1,361,700$ & $\$ 177,021$ & $\$ 5,058$ & $\$ 1,982,500$ & 12 \\
\hline Guayama & 18.4 & 116,305 & 450 & 720,900 & $\$ 93,717$ & $\$ 2,678$ & $\$ 1,002,500$ & 11 \\
\hline Guaynabo & 18.4 & 73,799 & 300 & 480,600 & $\$ 62,478$ & $\$ 1,785$ & $\$ 635,000$ & 10 \\
\hline Santa Isabel & 18.4 & 159,523 & 600 & 961,200 & $\$ 124,956$ & $\$ 3,570$ & $\$ 1,370,000$ & 11 \\
\hline Toa Alta & 18.4 & 87,038 & 350 & 560,700 & $\$ 72,891$ & $\$ 2,083$ & $\$ 757,500$ & 11 \\
\hline Toa Baja & 18.4 & 134,652 & 500 & 801,000 & $\$ 104,130$ & $\$ 2,975$ & $\$ 1,125,000$ & 11 \\
\hline All Site Total & 18.4 & $2,683,923$ & 10,550 & $16,901,100$ & $\$ 2,197,143$ & $\$ 62,773$ & $\$ 25,147,500$ & 12 \\
\hline \multicolumn{9}{|c|}{ Crystalline Silicon (Single-axis Tracking) } \\
\hline Cataño & 0 & 220,738 & 700 & $1,396,143$ & $\$ 181,499$ & $\$ 12,250$ & $\$ 2,350,000$ & 14 \\
\hline Guayama & 0 & 116,305 & 350 & 698,072 & $\$ 90,749$ & $\$ 6,125$ & $\$ 1,125,000$ & 13 \\
\hline Guaynabo & 0 & 73,799 & 250 & 498,623 & $\$ 64,821$ & $\$ 4,375$ & $\$ 775,000$ & 13 \\
\hline San Juan & 0 & $1,891,868$ & 6,200 & $12,365,838$ & $\$ 1,607,559$ & $\$ 108,500$ & $\$ 21,600,000$ & 14 \\
\hline Santa Isabel & 0 & 159,523 & 500 & 997,245 & $\$ 129,642$ & $\$ 8,750$ & $\$ 1,650,000$ & 14 \\
\hline Toa Alta & 0 & 87,038 & 250 & 498,623 & $\$ 64,821$ & $\$ 4,375$ & $\$ 775,000$ & 13 \\
\hline Toa Baja & 0 & 134,652 & 650 & $1,296,419$ & $\$ 168,534$ & $\$ 11,375$ & $\$ 2,175,000$ & 14 \\
\hline All Site Total & 0 & $2,683,923$ & 8,900 & $17,750,963$ & $\$ 2,307,625$ & $\$ 155,750$ & $\$ 30,450,000$ & 14 \\
\hline \multicolumn{9}{|c|}{ Thin Film ( Fixed Tilt) } \\
\hline Cataño & 18.4 & 220,738 & 350 & 560,700 & $\$ 72,891$ & $\$ 1,904$ & $\$ 684,000$ & 10 \\
\hline Guayama & 18.4 & 116,305 & 200 & 320,400 & $\$ 41,652$ & $\$ 1,088$ & $\$ 348,000$ & 9 \\
\hline Guaynabo & 18.4 & 73,799 & 100 & 160,200 & $\$ 20,826$ & $\$ 544$ & $\$ 124,000$ & 6 \\
\hline
\end{tabular}

${ }^{29}$ The calculations in Appendix A assume that the $30 \%$ federal tax credit is secured. 


\begin{tabular}{|c|c|c|c|c|c|c|c|c|}
\hline Location & $\begin{array}{l}\text { Array Tilt } \\
\text { (Deg) }\end{array}$ & $\begin{array}{l}\text { Max Usable Area } \\
\left(\mathrm{ft}^{2}\right)\end{array}$ & $\begin{array}{l}\text { Rounded PV System } \\
\text { Size (kW) }\end{array}$ & $\begin{array}{l}\text { Annual Output } \\
\text { (kWh/year) }\end{array}$ & $\begin{array}{l}\text { Annual Cost Savings } \\
\text { (\$/year) }\end{array}$ & $\begin{array}{l}\text { Annual O\&M } \\
\text { (\$/year) }\end{array}$ & $\begin{array}{l}\text { System Cost with } \\
\text { Incentives (\$) }\end{array}$ & $\begin{array}{l}\text { Payback Period } \\
\text { (years) }\end{array}$ \\
\hline Santa Isabel & 18.4 & 159,523 & 250 & 400,500 & $\$ 52,065$ & $\$ 1,360$ & $\$ 460,000$ & 9 \\
\hline Toa Alta & 18.4 & 87,038 & 150 & 240,300 & $\$ 31,239$ & $\$ 816$ & $\$ 236,000$ & 8 \\
\hline Toa Baja & 18.4 & 134,652 & 350 & 560,700 & $\$ 72,891$ & $\$ 1,904$ & $\$ 684,000$ & 10 \\
\hline All Site Total & 18.4 & $2,683,923$ & 4,600 & $7,369,200$ & $\$ 957,996$ & $\$ 25,024$ & $\$ 9,604,000$ & 10 \\
\hline
\end{tabular}

Table A-2. Assumptions for Calculations for Roof-mounted PV Systems Assuming \$6.00/W for Crystalline Silicon and $\$ 5.40 / W$ for Thin-film Systems

\begin{tabular}{|c|c|c|c|c|c|c|c|c|}
\hline Location & $\begin{array}{l}\text { Array Tilt } \\
\text { (Deg) }\end{array}$ & $\begin{array}{l}\text { Max Usable } \\
\text { Area }\left(\mathrm{ft}^{2}\right)\end{array}$ & $\begin{array}{l}\text { Rounded PV System } \\
\text { Size (kW) }\end{array}$ & $\begin{array}{l}\text { Annual Output } \\
\text { (kWh/year) }\end{array}$ & $\begin{array}{l}\text { Annual Cost } \\
\text { Savings (\$/year) }\end{array}$ & $\begin{array}{l}\text { Annual O\&M } \\
\text { (\$/year) }\end{array}$ & $\begin{array}{l}\text { System Cost with } \\
\text { Incentives (\$) }\end{array}$ & $\begin{array}{l}\text { Payback Period } \\
\text { (years) }\end{array}$ \\
\hline \multicolumn{9}{|c|}{ Crystalline Silicon (Fixed Tilt) } \\
\hline Guaynabo Recycling Center & 10.0 & 5,585 & 50 & 80,100 & $\$ 10,413$ & $\$ 510$ & $\$ 110,000$ & 11 \\
\hline All Site Total & 10.0 & 5,585 & 50 & 80,100 & $\$ 10,413$ & $\$ 510$ & $\$ 110,000$ & 11 \\
\hline \multicolumn{9}{|l|}{ Thin Film ( Fixed Tilt) } \\
\hline Guaynabo Recycling Center & 10.0 & 5,585 & 25 & 40,050 & $\$ 5,207$ & $\$ 230$ & $\$ 27,000$ & 5 \\
\hline All Site Total & 10.0 & 5,585 & 25 & 40,050 & $\$ 5,207$ & $\$ 230$ & $\$ 27,000$ & 5 \\
\hline
\end{tabular}

Table A-3. Assumptions for Calculations for Ground-mounted PV Systems Assuming \$7.00/W for Crystalline Silicon Fixed-tilt Systems, $\$ 10.00 / W$ for Single-axis Tracking Systems, and $\$ 6.40 / \mathrm{W}$ for Thin-film Fixed-tilt Systems

\begin{tabular}{|c|c|c|c|c|c|c|c|c|}
\hline Location & $\begin{array}{l}\text { Array Tilt } \\
\text { (Deg) }\end{array}$ & $\begin{array}{l}\text { Max Usable Area } \\
\left(\mathrm{ft}^{2}\right)\end{array}$ & $\begin{array}{l}\text { Rounded PV System } \\
\text { Size (kW) }\end{array}$ & $\begin{array}{l}\text { Annual Output } \\
\text { (kWh/year) }\end{array}$ & $\begin{array}{l}\text { Annual Cost Savings } \\
\text { (\$/year) }\end{array}$ & $\begin{array}{l}\text { Annual O\&M } \\
\text { (\$/year) }\end{array}$ & $\begin{array}{l}\text { System Cost with } \\
\text { Incentives (\$) }\end{array}$ & $\begin{array}{l}\text { Payback Period } \\
\text { (years) }\end{array}$ \\
\hline \multicolumn{9}{|c|}{ Crystalline Silicon (Fixed Tilt) } \\
\hline Cataño & 18.4 & 220,738 & 850 & $1,361,700$ & $\$ 177,021$ & $\$ 10,115$ & $\$ 4,065,000$ & 24 \\
\hline Guayama & 18.4 & 116,305 & 450 & 720,900 & $\$ 93,717$ & $\$ 5,355$ & $\$ 2,105,000$ & 24 \\
\hline Guaynabo & 18.4 & 73,799 & 300 & 480,600 & $\$ 62,478$ & $\$ 3,570$ & $\$ 1,370,000$ & 23 \\
\hline San Juan & 18.4 & $1,891,868$ & 7,500 & $12,015,000$ & $\$ 1,561,950$ & $\$ 89,250$ & $\$ 36,650,000$ & 25 \\
\hline Santa Isabel & 18.4 & 159,523 & 600 & 961,200 & $\$ 124,956$ & $\$ 7,140$ & $\$ 2,840,000$ & 24 \\
\hline Toa Alta & 18.4 & 87,038 & 350 & 560,700 & $\$ 72,891$ & $\$ 4,165$ & $\$ 1,615,000$ & 23 \\
\hline Toa Baja & 18.4 & 134,652 & 500 & 801,000 & $\$ 104,130$ & $\$ 5,950$ & $\$ 2,350,000$ & 24 \\
\hline All Site Total & 18.4 & $2,683,923$ & 10,550 & $16,901,100$ & $\$ 2,197,143$ & $\$ 125,545$ & $\$ 50,995,000$ & 25 \\
\hline \multicolumn{9}{|c|}{ Crystalline Silicon (Single-axis Tracking) } \\
\hline Cataño & 0 & 220,738 & 700 & $1,396,143$ & $\$ 181,499$ & $\$ 24,500$ & $\$ 4,800,000$ & 31 \\
\hline Guayama & 0 & 116,305 & 350 & 698,072 & $\$ 90,749$ & $\$ 12,250$ & $\$ 2,350,000$ & 30 \\
\hline Guaynabo & 0 & 73,799 & 250 & 498,623 & $\$ 64,821$ & $\$ 8,750$ & $\$ 1,650,000$ & 29 \\
\hline
\end{tabular}




\begin{tabular}{|c|c|c|c|c|c|c|c|c|}
\hline Location & $\begin{array}{l}\text { Array Tilt } \\
\text { (Deg) }\end{array}$ & $\begin{array}{l}\text { Max Usable Area } \\
\left(\mathrm{ft}^{2}\right)\end{array}$ & $\begin{array}{l}\text { Rounded PV System } \\
\text { Size (kW) } \\
\end{array}$ & $\begin{array}{l}\text { Annual Output } \\
\text { (kWh/year) }\end{array}$ & $\begin{array}{l}\text { Annual Cost Savings } \\
\text { (\$/year) }\end{array}$ & $\begin{array}{l}\text { Annual O\&M } \\
\text { (\$/year) }\end{array}$ & $\begin{array}{l}\text { System Cost with } \\
\text { Incentives (\$) }\end{array}$ & $\begin{array}{l}\text { Payback Period } \\
\text { (years) }\end{array}$ \\
\hline San Juan & 0 & $1,891,868$ & 6,200 & $12,365,838$ & $\$ 1,607,559$ & $\$ 217,000$ & $\$ 43,300,000$ & 31 \\
\hline Santa Isabel & 0 & 159,523 & 500 & 997,245 & $\$ 129,642$ & $\$ 17,500$ & $\$ 3,400,000$ & 30 \\
\hline Toa Alta & 0 & 87,038 & 250 & 498,623 & $\$ 64,821$ & $\$ 8,750$ & $\$ 1,650,000$ & 29 \\
\hline Toa Baja & 0 & 134,652 & 650 & $1,296,419$ & $\$ 168,534$ & $\$ 22,750$ & $\$ 4,450,000$ & 31 \\
\hline All Site Total & 0 & $2,683,923$ & 8,900 & $17,750,963$ & $\$ 2,307,625$ & $\$ 311,500$ & $\$ 61,600,000$ & 31 \\
\hline \multicolumn{9}{|c|}{ Thin Film ( Fixed Tilt) } \\
\hline Cataño & 18.4 & 220,738 & 350 & 560,700 & $\$ 72,891$ & $\$ 3,808$ & $\$ 1,468,000$ & 21 \\
\hline Guayama & 18.4 & 116,305 & 200 & 320,400 & $\$ 41,652$ & $\$ 2,176$ & $\$ 796,000$ & 20 \\
\hline Guaynabo & 18.4 & 73,799 & 100 & 160,200 & $\$ 20,826$ & $\$ 1,088$ & $\$ 348,000$ & 18 \\
\hline San Juan & 18.4 & $1,891,868$ & 3,200 & $5,126,400$ & $\$ 666,432$ & $\$ 34,816$ & $\$ 14,236,000$ & 23 \\
\hline Santa Isabel & 18.4 & 159,523 & 250 & 400,500 & $\$ 52,065$ & $\$ 2,720$ & $\$ 1,020,000$ & 21 \\
\hline Toa Alta & 18.4 & 87,038 & 150 & 240,300 & $\$ 31,239$ & $\$ 1,632$ & $\$ 572,000$ & 19 \\
\hline Toa Baja & 18.4 & 134,652 & 350 & 560,700 & $\$ 72,891$ & $\$ 3,808$ & $\$ 1,468,000$ & 21 \\
\hline All Site Total & 18.4 & $2,683,923$ & 4,600 & $7,369,200$ & $\$ 957,996$ & $\$ 50,048$ & $\$ 19,908,000$ & 22 \\
\hline
\end{tabular}

Table A-4. Assumptions for Calculations for Roof-mounted PV Systems Assuming \$9.33/W for Crystalline Silicon and \$8.73/W for Thin-film Systems

\begin{tabular}{|c|c|c|c|c|c|c|c|c|}
\hline Location & $\begin{array}{l}\text { Array Tilt } \\
\text { (Deg) }\end{array}$ & $\begin{array}{l}\text { Max Usable } \\
\text { Area }\left(\mathrm{ft}^{2}\right)\end{array}$ & $\begin{array}{l}\text { Rounded PV System } \\
\text { Size (kW) }\end{array}$ & $\begin{array}{l}\text { Annual Output } \\
\text { (kWh/year) }\end{array}$ & $\begin{array}{l}\text { Annual Cost } \\
\text { Savings (\$/year) }\end{array}$ & $\begin{array}{l}\text { Annual O\&M } \\
\text { (\$/year) }\end{array}$ & $\begin{array}{l}\text { System Cost with } \\
\text { Incentives (\$) }\end{array}$ & $\begin{array}{l}\text { Payback Period } \\
\text { (years) }\end{array}$ \\
\hline \multicolumn{9}{|l|}{ Crystalline Silicon (Fixed Tilt) } \\
\hline Guaynabo Recycling Center & 10.0 & 5,585 & 50 & 80,100 & $\$ 10,413$ & $\$ 793$ & $\$ 226,550$ & 24 \\
\hline All Site Total & 10.0 & 5,585 & 50 & 80,100 & $\$ 10,413$ & $\$ 793$ & $\$ 226,550$ & 24 \\
\hline \multicolumn{9}{|l|}{ Thin Film ( Fixed Tilt) } \\
\hline Guaynabo Recycling Center & 10.0 & 5,585 & 25 & 40,050 & $\$ 5,207$ & $\$ 371$ & $\$ 43,650$ & 9 \\
\hline All Site Total & 10.0 & 5,585 & 25 & 40,050 & $\$ 5,207$ & $\$ 371$ & $\$ 43,650$ & 9 \\
\hline
\end{tabular}


Table A-5. Other Assumptions, Including Assumptions for Costs and System Types

\begin{tabular}{|c|c|c|c|c|}
\hline \multicolumn{5}{|l|}{ Cost Assumptions } \\
\hline Variable & Quantity of Variable & \multicolumn{3}{|l|}{ Unit of Variable } \\
\hline Buyback Electricity Rate & $\$ 0.13$ & \multicolumn{3}{|l|}{$\$ / k W h$} \\
\hline Annual O\&M (Fixed) & $0.17 \%$ & \multicolumn{3}{|l|}{$\%$ of installed cost } \\
\hline Annual O\&M (Tracking) & $0.35 \%$ & \multicolumn{3}{|l|}{$\%$ of installed cost } \\
\hline $\begin{array}{c}\text { System Assumptions } \\
\text { System Type }\end{array}$ & $\begin{array}{l}\text { Annual Energy } \\
\text { (kWh/kW) }\end{array}$ & $\begin{array}{l}\text { Low Installed } \\
\text { Cost Assumption } \\
\text { (\$/W) }\end{array}$ & $\begin{array}{l}\text { High Installed } \\
\text { Cost } \\
\text { Assumption } \\
(\$ / W)\end{array}$ & $\begin{array}{l}\text { Energy } \\
\text { Density } \\
\left(\mathrm{W} / \mathrm{ft}^{2}\right)\end{array}$ \\
\hline Ground Crystalline Fixed & 1,602 & $\$ 3.50$ & $\$ 7.00$ & 4.0 \\
\hline $\begin{array}{l}\text { Ground Single-axis } \\
\text { Tracking }\end{array}$ & 1,994 & $\$ 5.00$ & $\$ 10.00$ & 3.3 \\
\hline Ground Thin-film Fixed & 1,602 & $\$ 3.20$ & $\$ 6.40$ & 1.7 \\
\hline Roof Crystalline Fixed & 1,602 & $\$ 6.00$ & $\$ 9.33$ & 10.0 \\
\hline Roof Thin-film Fixed & 1,602 & $\$ 5.40$ & $\$ 8.73$ & 4.3 \\
\hline \multirow[t]{2}{*}{ Other Assumptions } & Ground Utilization & \multicolumn{3}{|c|}{$90 \%$ of available area } \\
\hline & Incentives & \multicolumn{3}{|c|}{ Federal tax credit and state incentives } \\
\hline
\end{tabular}




\section{Appendix B. Renewable Energy Incentives ${ }^{30}$}

Table B-1. Redevelopment and Renewable Energy Incentives and Financing Tools

\begin{tabular}{|c|c|c|c|c|c|}
\hline Agency & Incentive Name & $\begin{array}{l}\text { Incentive (I), } \\
\text { Finance Tool } \\
\text { (FT) }\end{array}$ & Public & Private & Funding Range \\
\hline HUD & $\begin{array}{l}\text { Brownfield Economic Development } \\
\text { Initiative (BEDI) Competitive Grant } \\
\text { Program }\end{array}$ & $\mathrm{I}$ & $X$ & $X^{a}$ & $\begin{array}{l}\text { \$17.5 million appropriated in } \\
\text { FY2010; Award cap TBD as of } \\
2 / 27 / 10\end{array}$ \\
\hline HUD & Section 108 Loan Guarantee Program & $\mathrm{FT}$ & $X$ & $X^{b}$ & $\begin{array}{l}\text { Up to five times public entity's } \\
\text { latest approved CDBG amount }\end{array}$ \\
\hline
\end{tabular}

\footnotetext{
${ }^{30}$ The calculations in Appendix B assume that the 30\% federal tax credit is secured.
} 
Table B-2. Renewable Energy Development Incentives and Financing Tools Applicable to PV

\begin{tabular}{|c|c|c|c|c|c|}
\hline Agency & Incentive Name & $\begin{array}{l}\text { Incentive (I), } \\
\text { Finance Tool } \\
\text { (FT) }\end{array}$ & Public & Private & Funding Range \\
\hline DOE & Loan Guarantee Program & $\mathrm{FT}$ & $\mathrm{x}$ & $\mathrm{x}$ & Not specified \\
\hline DOE & $\begin{array}{l}\text { Renewable Energy Production } \\
\text { Incentive (REPI) }\end{array}$ & I & $x$ & & $\$ 0.021 / \mathrm{kW}$ \\
\hline HUD & $\begin{array}{l}\text { Community Development Block Grants } \\
\text { (CDBG) }\end{array}$ & I & $x$ & & $\begin{array}{l}\text { Based on community needs } \\
\text { formula }\end{array}$ \\
\hline Treasury & $\begin{array}{l}1603 \text { Renewable Energy Grant } \\
\text { Program } \\
\text { *option to ITC }\end{array}$ & I & & $x$ & $\begin{array}{l}30 \% \text { of the cost basis of the } \\
\text { renewable energy project }\end{array}$ \\
\hline Treasury & Business Energy ITC *option to 1603 & I & & $x$ & $30 \%$ of project expenditures \\
\hline Treasury & $\begin{array}{l}\text { Clean Renewable Energy Bonds } \\
\text { (CREB) }\end{array}$ & $\mathrm{FT}$ & $x$ & & Varies \\
\hline Treasury & $\begin{array}{l}\text { Modified Accelerated Cost-Recovery } \\
\text { System (MACRS) }\end{array}$ & FT & & $x$ & Various depreciation deductions \\
\hline Treasury & $\begin{array}{l}\text { Qualified Energy Conservation Bonds } \\
\text { (QECB) }\end{array}$ & $\mathrm{FT}$ & $\mathrm{X}$ & & Varies \\
\hline USDA & $\begin{array}{l}\text { Rural Energy for America Program } \\
\text { (REAP) Grants }\end{array}$ & I & $x$ & $x$ & $\begin{array}{l}25 \% \text { of project cost; payment } \\
\text { range } \$ 2.5 \mathrm{~K}-\$ 500 \mathrm{~K}\end{array}$ \\
\hline USDA & $\begin{array}{l}\text { Rural Energy for America Program } \\
\text { (REAP) Loan Guarantees }\end{array}$ & $\mathrm{FT}$ & $x$ & $x$ & $\begin{array}{l}\text { Up to } 75 \% \text { of project costs; max. } \\
\$ 25 \text { million/min. } \$ 5,000\end{array}$ \\
\hline
\end{tabular}

Source: DSIRE. http://www.dsireusa.org/. Accessed September 2010. 


\section{Table B-3. State Rebates for Commercial-sector PV Projects}

The programs included here are ongoing rebate and grant programs administered by state agencies or by third-party organizations on behalf of state governments. In addition to the programs highlighted, about 75 utilities in the United States offer PV rebates. In some states, such as Colorado and Arizona, solar rebates from utilities are available nearly statewide that must comply with state RPSs, but these are not shown in the table. Finally, programs that are purely performance-based, such as Washington's production incentive and California's feed-in tariff, are not included in this table.

\begin{tabular}{|c|c|c|c|c|}
\hline State & Program Name & Incentive Amount & REC Ownership & Funding Source \\
\hline California & California Solar Initiative & Varies by sector and system size & $\begin{array}{l}\text { Remains with project } \\
\text { owner }\end{array}$ & Rate-payer funded \\
\hline California & $\begin{array}{l}\text { CEC - New Solar Homes } \\
\text { Partnership }\end{array}$ & $\begin{array}{l}\text { Varies. Incentives are adjusted } \\
\text { based on expected performance and } \\
\text { will decline over time based on the } \\
\text { total installed capacity. }\end{array}$ & $\begin{array}{l}\text { Remains with system } \\
\text { owner }\end{array}$ & Rate-payer funded \\
\hline Connecticut & $\begin{array}{l}\text { Connecticut Clean } \\
\text { Energy Fund (CCEF) - } \\
\text { On-Site Renewable DG } \\
\text { Program }\end{array}$ & $\begin{array}{l}\text { For-profit owners: } \$ 3.00 / W \text { for first } \\
100 \mathrm{~kW}, \$ 2.00 / \mathrm{W} \text { for next } 100 \mathrm{~kW} \text {. } \\
\text { Not-for-profit owners: } \$ 4.50 / \mathrm{W} \text { for } \\
\text { first } 100 \mathrm{~kW}, \$ 4.00 / \mathrm{W} \text { for next } 100 \\
\text { kW. Additional } \$ 0.10 / \mathrm{W} \text { premium for } \\
\text { buildings that meet LEED Silver } \\
\text { certification; CCEF also } \\
\text { compensates system owners based } \\
\text { on the estimated present value of the } \\
\text { system's RECs. }\end{array}$ & $\begin{array}{l}\text { RECs transfer to CCEF } \\
\text { for systems } 50 \mathrm{~kW} \text {-PTC } \\
\text { and larger. CCEF } \\
\text { compensates system } \\
\text { owners based on } \\
\text { estimated present value } \\
\text { of the system's RECs } \\
\text { over } 15 \text { years. }\end{array}$ & CCEF (public benefits fund) \\
\hline Delaware & $\begin{array}{l}\text { Green Energy Program } \\
\text { Incentives }\end{array}$ & $\begin{array}{l}\text { Delmarva: } 25 \% \text { of installed cost } \\
\text { (35\% for non-profits and } \\
\text { government); DEC: } 33.3 \% \text { of } \\
\text { installed cost; Minis: } 33.3 \% \text { of } \\
\text { installed cost, except } 25 \% \text { for Dover } \\
\text { and Seaford; PV system cost may } \\
\text { not exceed } \$ 12 / \mathrm{W}\end{array}$ & $\begin{array}{l}\text { Remains with project } \\
\text { owner }\end{array}$ & $\begin{array}{l}\text { Green Energy Fund (Delmarva), } \\
\text { DEC Renewable Resources } \\
\text { Fund, Municipal Utility Green } \\
\text { Energy Fund (public benefits } \\
\text { funds) }\end{array}$ \\
\hline $\begin{array}{l}\text { District of } \\
\text { Columbia }\end{array}$ & $\begin{array}{l}\text { Renewable Energy } \\
\text { Incentive Program }\end{array}$ & $\begin{array}{l}\text { \$3/DC-Watt for first } 3 \mathrm{~kW} ; \$ 2 / \mathrm{DC}- \\
\text { Watt for next } 7 \mathrm{~kW} ; \$ 1 / \mathrm{DC}-\text { Watt for } \\
\text { next } 10 \mathrm{~kW}\end{array}$ & $\begin{array}{l}\text { Remains with system } \\
\text { owner }\end{array}$ & $\begin{array}{l}\text { Sustainable Energy Trust Fund } \\
\text { (public benefits fund) }\end{array}$ \\
\hline
\end{tabular}




\begin{tabular}{lll}
\hline \multicolumn{1}{c}{ State } & \multicolumn{1}{c}{ Program Name } & \multicolumn{1}{c}{ Incentive Amount } \\
\hline Florida & $\begin{array}{l}\text { Solar Energy System } \\
\text { Incentives Program }\end{array}$ & \$4/DC-Watt \\
Illinois & $\begin{array}{l}\text { DCEO - Solar and Wind } \\
\text { Energy Rebate Program }\end{array}$ & $\begin{array}{l}\text { Note }(02 / 2010): \text { Funding for FY } 2010 \\
\text { has been fully allocated; no } \\
\text { additional rebates are available. } \\
\end{array}$ \\
& & $\begin{array}{l}\text { Residential and commercial: } 30 \% ; \\
\text { non-profit and public: } 50 \%\end{array}$ \\
Maine & Solar and Wind Energy & \$2/AC-Watt \\
& Rebate Program &
\end{tabular}

REC Ownership
Remains with system
owner

Funding Source

General Revenue Funds (appropriated annually)

Remains with

customer/producer

Illinois Renewable Energy

Resources Trust Fund (public benefits fund)

Remains with customer/producer

Funded by assessment of up to 0.005 cents $/ \mathrm{kWh}$ on transmission and distribution utilities; plus $\$ 500,000$ per fiscal year (FY2009-2010 and FY20102011) for two years using Recovery Act funding.

Maryland Mid-size Solar Energy Grant Program

Maryland Solar Energy Grant Program

Massachusetts

CEC - Commonwealth Solar II Rebates

$\$ 500 / \mathrm{kW}$ for first $20 \mathrm{~kW}$; $\$ 250 / \mathrm{kW}$ for next $30 \mathrm{~kW}$; $\$ 150 / \mathrm{kW}$ for next $50 \mathrm{~kW}$

$\$ 1.25 / \mathrm{DC}$-Watt for first $2 \mathrm{~kW}$;

$\$ 0.75 / \mathrm{W}$ for next $6 \mathrm{~kW} ; \$ 0.25 / \mathrm{W}$ for next $12 \mathrm{~kW}$

Remains with project

Recovery Act

\section{owner}

Remains with project owner

\section{General Revenue Funds} (appropriated annually); FY 2009 funds supplemented with RGGI proceeds

\$1.00/DC-Watt base; \$0.10/DC-Watt adder for MA components;

Remains with project owner

Massachusetts Renewable Energy Trust

\$1.00/DC-Watt adder for moderate home value or for moderate income

Massachusetts CEC - Commonwealth Solar Stimulus

\$1.50/DC-Watt for first $25 \mathrm{~kW}$; $\$ 1.00 / D C-W a t t$ for $25-100 \mathrm{~kW}$; \$0.50/DC-Watt for 100-200 kW

Nevada

NV Energy - Renewable Generations Rebate

Program

(2010-2011 program year)

owner

\section{Recovery Act}

Residential and small business:

\$2.30/AC-Watt; public

facilities/schools: $\$ 5.00 / A C-W a t t$

New Jersey New Jersey Customersited Renewable Energy Rebates

Standard residential: \$1.55/DC-Watt; Residential with energy efficiency: \$1.75/DC-Watt; residential new construction: varies by efficiency, \$1.00-1.75/DC-Watt; standard non-

Rate-payer funded

New Jersey Societal Benefits Charge (public benefits fund) 


\begin{tabular}{|c|c|c|c|c|}
\hline State & Program Name & Incentive Amount & REC Ownership & Funding Source \\
\hline & & $\begin{array}{l}\text { residential: \$0.90/DC-Watt; non- } \\
\text { residential with efficiency: } \$ 1.00 / D C- \\
\text { Watt }\end{array}$ & & \\
\hline New Jersey & $\begin{array}{l}\text { Renewable Energy } \\
\text { Manufacturing Incentives } \\
\text { (for end-use PV } \\
\text { installations) }\end{array}$ & $\begin{array}{l}\text { Varies by equipment type, sector, } \\
\text { and system size; ranges from } \$ 0.05- \\
\text { \$0.55/DC-Watt. }\end{array}$ & Not applicable & $\begin{array}{l}\text { New Jersey Societal Benefits } \\
\text { Charge (public benefits fund) }\end{array}$ \\
\hline New York & $\begin{array}{l}\text { NYSERDA - PV Incentive } \\
\text { Program }\end{array}$ & $\begin{array}{l}\text { Residential (first } 5 \mathrm{~kW} \text { ): } \$ 1.75 / \mathrm{DC}- \\
\text { Watt; non-residential (first } 50 \mathrm{~kW} \text { ): } \\
\text { \$1.75/DC-Watt; non-profit, } \\
\text { government, schools (first } 25 \mathrm{~kW} \text { ): } \\
\text { \$1.75/DC-Watt; bonus incentive: } \\
\text { \$0.50/W for Energy Star homes and } \\
\text { BIPV systems }\end{array}$ & $\begin{array}{l}\text { First } 3 \text { years: } \\
\text { NYSERDA, thereafter } \\
\text { customer/generator }\end{array}$ & RPS surcharge \\
\hline Ohio & $\begin{array}{l}\text { ODOD - Advanced } \\
\text { Energy Program Grants - } \\
\text { Non-residential } \\
\text { Renewable Energy } \\
\text { Incentive }\end{array}$ & $\begin{array}{l}\$ 3.50 / D C-W a t t, \text { may be reduced by } \\
\text { shading }\end{array}$ & Not specified & Ohio Advanced Energy Fund \\
\hline Oregon & $\begin{array}{l}\text { Energy Trust - Solar } \\
\text { Electric Buy-down } \\
\text { Program }\end{array}$ & $\begin{array}{l}\text { Residential: \$1.50/DC-Watt for } \\
\text { Pacific Power; \$1.75/DC-Watt for } \\
\text { PGE; residential, third-party: \$1/DC- } \\
\text { Watt for Pacific Power; } \$ 1.25 / D C- \\
\text { Watt for PGE; commercial: } \$ 0.50- \\
1.00 / W \text { for Pacific Power; } \$ 0.75- \\
1.25 / \text { W for PGE; non- } \\
\text { profit/government: } \$ 0.75-1.25 / \mathrm{W} \text { for } \\
\text { Pacific Power; } \$ 1.00-1.50 / \mathrm{W} \text { for } \\
\text { PGE }\end{array}$ & $\begin{array}{l}\text { Residential: RECs for } \\
\text { first } 5 \text { years owned by } \\
\text { customer/producer; } \\
\text { non-residential: RECs } \\
\text { for first } 5 \text { years owned } \\
\text { by consumer/producer, } \\
\text { then Energy Trust owns } \\
\text { RECs for years } 6-20\end{array}$ & $\begin{array}{l}\text { Energy Trust of Oregon (public } \\
\text { benefits fund) }\end{array}$ \\
\hline Pennsylvania & $\begin{array}{l}\text { Pennsylvania Sunshine } \\
\text { Solar Rebate Program }\end{array}$ & $\begin{array}{l}\text { Residential: } \$ 2.25 / D C-W a t t ; \\
\text { commercial: } \$ 1.25 / D C-W a t \text { for first } \\
10 \mathrm{~kW}, \$ 1.00 / D C-W a t t \text { for next } 90 \\
\text { kW, } \$ 0.75 / D C-W a t t \text { for next } 100 \mathrm{~kW} \text {; } \\
\text { low-Income: } 35 \% \text { of installed costs }\end{array}$ & $\begin{array}{l}\text { Not specified; net- } \\
\text { metering customers } \\
\text { generally retain title to } \\
\text { RECs }\end{array}$ & $\begin{array}{l}\text { Pennsylvania Energy } \\
\text { Independence Fund (state bonds) }\end{array}$ \\
\hline Puerto Rico & $\begin{array}{l}\text { Puerto Rico - State } \\
\text { Energy Program - Sun } \\
\text { Energy Rebate Program }\end{array}$ & $\begin{array}{l}\text { Solar PV: residential and commercial } \\
\text { \$4/DC-Watt; governmental \$8/DC- } \\
\text { Watt }\end{array}$ & Not addressed & $\begin{array}{l}\text { Recovery Act State Energy } \\
\text { Program funds }\end{array}$ \\
\hline
\end{tabular}




\begin{tabular}{|c|c|c|c|c|}
\hline State & Program Name & Incentive Amount & REC Ownership & Funding Source \\
\hline Tennessee & $\begin{array}{l}\text { Tennessee Clean Energy } \\
\text { Technology Grant }\end{array}$ & $40 \%$ of installed cost & Not specified & $\begin{array}{l}\text { State of Tennessee Economic } \\
\text { and Community Development } \\
\text { Energy Division }\end{array}$ \\
\hline Vermont & $\begin{array}{l}\text { Vermont Small-scale } \\
\text { Renewable Energy } \\
\text { Incentive Program }\end{array}$ & $\begin{array}{l}\text { Individuals/businesses: } \$ 1.75 / D C \text { - } \\
\text { Watt; multi-family, low-income: } \\
\text { \$3.50/DC-Watt }\end{array}$ & Not addressed & $\begin{array}{l}\text { Utility settlement funds and the } \\
\text { Vermont Clean Energy } \\
\text { Development Fund }\end{array}$ \\
\hline Wisconsin & $\begin{array}{l}\text { Focus on Energy - } \\
\text { Renewable Energy Cash- } \\
\text { back Rewards }\end{array}$ & $\begin{array}{l}\text { Residential/businesses: } \$ 1.00 / \mathrm{kWh} \\
\text { for one year; non-profit/government: } \\
\$ 1.50 / \mathrm{kWh} \text { for one year (estimated } \\
\text { one-year production using } \\
\text { PVWATTS). Efficiency First } \\
\text { participants: add } \$ 0.25 / \mathrm{kWh} \text { for one } \\
\text { year. }\end{array}$ & Not addressed & Focus on Energy Program \\
\hline
\end{tabular}

Source: DSIRE. http://www.dsireusa.org/. Accessed September 2010.

Note: The information provided in this table presents an overview of state incentives, but it should not be used as the only source of information when making purchasing decisions, investment decisions, tax decisions, or other binding agreements. For more information about individual programs listed above, visit the DSIRE website at http://www.dsireusa.org/. 
Table B-4. State Tax Credits for Commercial-sector PV Projects

\begin{tabular}{|c|c|c|c|c|c|}
\hline State & Program Name & Eligible Recipients & $\begin{array}{l}\text { Incentive } \\
\text { Amount }\end{array}$ & $\begin{array}{c}\text { Third-party Owner } \\
\text { Eligible }\end{array}$ & $\begin{array}{c}\text { Non-profit/Government } \\
\text { Eligible }\end{array}$ \\
\hline Arizona & $\begin{array}{l}\text { Non-residential } \\
\text { Solar \& Wind } \\
\text { Tax Credit } \\
\text { (Corporate) }\end{array}$ & $\begin{array}{l}\text { Any non-residential installation is } \\
\text { eligible, including those for non- } \\
\text { profits and governments. } \\
\text { Individuals, corporations and S } \\
\text { corporations, and partnerships may } \\
\text { claim the credit. Third-party } \\
\text { financiers/installers/mfrs. of an } \\
\text { eligible system may claim the credit. }\end{array}$ & $10 \%$ & Yes & Yes \\
\hline Florida & $\begin{array}{l}\text { Renewable } \\
\text { Energy } \\
\text { Production Tax } \\
\text { Credit }\end{array}$ & $\begin{array}{l}\text { A non-residential taxpayer with } \\
\text { facility placed in service or } \\
\text { expanded after May } 1,2006 \text {. The } \\
\text { credit is for electricity produced and } \\
\text { sold by the taxpayer to an unrelated } \\
\text { party during a given tax year. } \\
\text { Florida corporate income taxpayers } \\
\text { who own an interest in a general } \\
\text { partnership, limited partnership, } \\
\text { limited liability company, trust, or } \\
\text { other artificial entity that owns a } \\
\text { Florida renewable energy facility } \\
\text { can apply for this credit. }\end{array}$ & $\$ 0.01 / \mathrm{kWh}$ & Not specified & Not specified \\
\hline Georgia & $\begin{array}{l}\text { Clean Energy } \\
\text { Tax Credit } \\
\text { (Corporate) }\end{array}$ & $\begin{array}{l}\text { Taxpayer who has constructed, } \\
\text { purchased, or leased renewable } \\
\text { energy property and placed it in } \\
\text { service. }\end{array}$ & $35 \%$ & Yes & Not specified \\
\hline Hawaii & $\begin{array}{l}\text { Solar and Wind } \\
\text { Energy Credit } \\
\text { (Corporate) }\end{array}$ & $\begin{array}{l}\text { Taxpayer that files a corporate net } \\
\text { income tax return or franchise tax } \\
\text { return; credit may be claimed for } \\
\text { every eligible renewable energy } \\
\text { technology system that is installed } \\
\text { and placed in service. Third-party } \\
\text { taxpaying entities may claim the } \\
\text { credit if they install and own a } \\
\text { system on a commercial taxpayer's } \\
\text { building or on a non-profit or }\end{array}$ & $35 \%$ & Yes & Yes \\
\hline
\end{tabular}




\begin{tabular}{|c|c|c|c|c|c|}
\hline State & Program Name & Eligible Recipients & $\begin{array}{c}\text { Incentive } \\
\text { Amount }\end{array}$ & $\begin{array}{c}\text { Third-party Owner } \\
\text { Eligible }\end{array}$ & $\begin{array}{c}\text { Non-profit/Government } \\
\text { Eligible }\end{array}$ \\
\hline & & $\begin{array}{l}\text { government building. Multiple } \\
\text { owners of a single system may take } \\
\text { a single tax credit. The credit is } \\
\text { apportioned between the owners in } \\
\text { proportion to their contribution to the } \\
\text { system's cost. }\end{array}$ & & & \\
\hline lowa & $\begin{array}{l}\text { Renewable } \\
\text { Energy } \\
\text { Production Tax } \\
\text { Credits } \\
\text { (Corporate) }\end{array}$ & $\begin{array}{l}\text { Producers or purchasers of } \\
\text { renewable energy from qualified } \\
\text { facilities; installations must be at } \\
\text { least } 51 \% \text { owned by a state resident } \\
\text { or other qualifying owner and placed } \\
\text { in service on or after July } 1,2005 \text {, } \\
\text { and before January } 1,2012 \text {. } \\
\text { Electricity must be sold to an } \\
\text { unrelated person to qualify for the } \\
\text { tax credit. }\end{array}$ & $\begin{array}{l}\$ 0.015 / \mathrm{kWh} \text { for } \\
10 \text { years after } \\
\text { energy } \\
\text { production } \\
\text { begins }\end{array}$ & $\begin{array}{l}\text { Yes, credits may be } \\
\text { claimed by system owner } \\
\text { or by purchaser of } \\
\text { electricity. System owners } \\
\text { must meet certain eligibility } \\
\text { criteria. }\end{array}$ & $\begin{array}{l}\text { Schools and cooperative } \\
\text { associations are eligible } \\
\text { owners. Credits may be } \\
\text { transferred or sold one } \\
\text { time. }\end{array}$ \\
\hline Kentucky & $\begin{array}{l}\text { Renewable } \\
\text { Energy Tax } \\
\text { Credit } \\
\text { (Corporate) }\end{array}$ & $\begin{array}{l}\text { Any installation on a dwelling unit or } \\
\text { on property that is owned and used } \\
\text { by the taxpayer as commercial } \\
\text { property. }\end{array}$ & \$3/DC-Watt & Not specified & Not specified \\
\hline Kentucky & $\begin{array}{l}\text { Tax Credit for } \\
\text { Renewable } \\
\text { Energy } \\
\text { Facilities }\end{array}$ & $\begin{array}{l}\text { Companies that build or renovate } \\
\text { facilities that utilize renewable } \\
\text { energy. }\end{array}$ & $\begin{array}{l}100 \% \text { Kentucky } \\
\text { income tax or } \\
\text { limited liability } \\
\text { entity tax }\end{array}$ & Not specified & Not specified \\
\hline Louisiana & $\begin{array}{l}\text { Tax Credit for } \\
\text { Solar and Wind } \\
\text { Energy } \\
\text { Systems on } \\
\text { Residential } \\
\text { Property } \\
\text { (Corporate) }\end{array}$ & $\begin{array}{l}\text { Taxpayer who purchases and } \\
\text { installs an eligible system or who } \\
\text { purchases a new home with such a } \\
\text { system already in place. }\end{array}$ & $50 \%$ & No & No \\
\hline Maryland & $\begin{array}{l}\text { Clean Energy } \\
\text { Production Tax } \\
\text { Credit } \\
\text { (Corporate) }\end{array}$ & $\begin{array}{l}\text { All individuals and corporations that } \\
\text { sell electricity produced by a } \\
\text { qualified facility to an unrelated } \\
\text { person; net-metering arrangements } \\
\text { qualify. }\end{array}$ & $\begin{array}{l}\$ 0.0085 / \mathrm{kWh} \\
\text { for } 5 \text { years after } \\
\text { facility is placed } \\
\text { in service }\end{array}$ & Not specified & No \\
\hline
\end{tabular}




\begin{tabular}{|c|c|c|c|c|c|}
\hline State & Program Name & Eligible Recipients & $\begin{array}{l}\text { Incentive } \\
\text { Amount }\end{array}$ & $\begin{array}{c}\text { Third-party Owner } \\
\text { Eligible }\end{array}$ & $\begin{array}{c}\text { Non-profit/Government } \\
\text { Eligible }\end{array}$ \\
\hline Montana & $\begin{array}{l}\text { Alternative } \\
\text { Energy } \\
\text { Investment Tax } \\
\text { Credit } \\
\text { (Corporate) }\end{array}$ & $\begin{array}{l}\text { Corporation, partnership, or small } \\
\text { business corporation that makes a } \\
\text { minimum investment of } \$ 5,000 \text {. }\end{array}$ & $35 \%$ & No & No \\
\hline $\begin{array}{l}\text { New } \\
\text { Mexico }\end{array}$ & $\begin{array}{l}\text { Advanced } \\
\text { Energy Tax } \\
\text { Credit } \\
\text { (Corporate) }\end{array}$ & Any taxpayer. & $6 \%$ & No & No \\
\hline $\begin{array}{l}\text { New } \\
\text { Mexico }\end{array}$ & $\begin{array}{l}\text { Renewable } \\
\text { Energy } \\
\text { Production Tax } \\
\text { Credit } \\
\text { (Corporate) }\end{array}$ & $\begin{array}{l}\text { Taxpayer who holds title to a } \\
\text { qualified energy generator that first } \\
\text { produced electricity on or before } \\
\text { January } 1,2018 \text {, or a taxpayer who } \\
\text { leases property upon which a } \\
\text { qualified energy generator operates } \\
\text { from a county or municipality under } \\
\text { authority of an industrial revenue } \\
\text { bond and if the qualified energy } \\
\text { generator first produced electricity } \\
\text { on or before January } 1,2018 \text {. }\end{array}$ & $\begin{array}{l}\text { Varies annually } \\
\text { over } 10 \text { years; } \\
\$ 0.027 / \mathrm{kWh} \\
\text { average }\end{array}$ & Not specified & Not specified \\
\hline $\begin{array}{l}\text { New } \\
\text { Mexico }\end{array}$ & $\begin{array}{l}\text { Solar Market } \\
\text { Development } \\
\text { Tax Credit }\end{array}$ & $\begin{array}{l}\text { Residents and non-corporate } \\
\text { businesses, including agricultural } \\
\text { enterprises. }\end{array}$ & $\begin{array}{l}10 \% \text { of } \\
\text { purchase and } \\
\text { installation } \\
\text { costs }\end{array}$ & No & No \\
\hline $\begin{array}{l}\text { North } \\
\text { Carolina }\end{array}$ & $\begin{array}{l}\text { Renewable } \\
\text { Energy Tax } \\
\text { Credit } \\
\text { (Corporate) }\end{array}$ & $\begin{array}{l}\text { Taxpayer who has constructed, } \\
\text { purchased, or leased renewable } \\
\text { energy property and placed it in } \\
\text { service. }\end{array}$ & $\begin{array}{l}35 \% \\
\text { (distributed } 7 \% \\
\text { per year for } 5 \\
\text { years for non- } \\
\text { residential } \\
\text { installations) }\end{array}$ & $\begin{array}{l}\text { Yes. For leasing, a } \\
\text { taxpayer may take credit } \\
\text { for property that the } \\
\text { taxpayer leases if written } \\
\text { verification is received } \\
\text { from the owner that states } \\
\text { that owner will not take } \\
\text { credit for renewable } \\
\text { energy installation. }\end{array}$ & No \\
\hline
\end{tabular}




\begin{tabular}{|c|c|c|c|c|c|}
\hline State & Program Name & Eligible Recipients & $\begin{array}{c}\text { Incentive } \\
\text { Amount }\end{array}$ & $\begin{array}{c}\text { Third-party Owner } \\
\text { Eligible }\end{array}$ & $\begin{array}{l}\text { Non-profit/Government } \\
\text { Eligible }\end{array}$ \\
\hline $\begin{array}{l}\text { North } \\
\text { Dakota }\end{array}$ & $\begin{array}{l}\text { Renewable } \\
\text { Energy Tax } \\
\text { Credit }\end{array}$ & $\begin{array}{l}\text { Corporate taxpayers filing a North } \\
\text { Dakota income tax return. System } \\
\text { must be installed on a building or on } \\
\text { property owned or leased by the } \\
\text { taxpayer in North Dakota. }\end{array}$ & $\begin{array}{l}15 \% \\
\text { (distributed } 3 \% \\
\text { per year for } 5 \\
\text { years) }\end{array}$ & $\begin{array}{l}\text { A pass-through entity that } \\
\text { installs the system at a } \\
\text { property it owns or leases } \\
\text { is considered the taxpayer. } \\
\text { The credit amount allowed } \\
\text { is determined at the pass- } \\
\text { through entity level and } \\
\text { must be passed through } \\
\text { proportionally to corporate } \\
\text { partners, shareholders, or } \\
\text { members. }\end{array}$ & No \\
\hline Oklahoma & $\begin{array}{l}\text { Zero-emission } \\
\text { Facilities } \\
\text { Production Tax } \\
\text { Credit }\end{array}$ & $\begin{array}{l}\text { Non-residential taxpayer who sells } \\
\text { electricity to an unrelated person; } \\
\text { non-taxable entities, including } \\
\text { agencies of the State of Oklahoma, } \\
\text { may transfer their credit to a } \\
\text { taxpayer. }\end{array}$ & $\begin{array}{l}\$ 0.0050 / \mathrm{kWh} \\
\text { for first } 10 \text { years } \\
\text { of operation }\end{array}$ & Yes & $\begin{array}{l}\text { Yes, nontaxable entities, } \\
\text { including agencies of the } \\
\text { State of Oklahoma, or } \\
\text { political subdivisions } \\
\text { thereof, can take } \\
\text { advantage of the tax credit } \\
\text { by transferring it to a } \\
\text { taxable entity. }\end{array}$ \\
\hline Oregon & $\begin{array}{l}\text { Business } \\
\text { Energy Tax } \\
\text { Credit }\end{array}$ & $\begin{array}{l}\text { Trade, business, or rental property } \\
\text { owners who pay taxes for a } \\
\text { business site in Oregon are eligible } \\
\text { for the tax credit. The business, its } \\
\text { partners, or its shareholders may } \\
\text { use the credit. A project owner also } \\
\text { can be an Oregon non-profit } \\
\text { organization, tribe, or public entity } \\
\text { that partners with an Oregon } \\
\text { business or resident who has an } \\
\text { Oregon tax liability. This can be } \\
\text { done using the pass-through option. }\end{array}$ & $\begin{array}{l}50 \% \\
\text { (distributed } \\
10 \% \text { per year } \\
\text { for } 5 \text { years) }\end{array}$ & Yes & $\begin{array}{l}\text { A project owner can be a } \\
\text { non-profit, tribe, or public } \\
\text { entity that partners with a } \\
\text { business or resident to } \\
\text { take advantage of the } \\
\text { pass-through option. The } \\
\text { pass-through option allows } \\
\text { a project owner to transfer } \\
\text { the } 35 \% \text { Business Energy } \\
\text { Tax Credit project eligibility } \\
\text { to a pass-through partner } \\
\text { for a lump-sum cash } \\
\text { payment. The pass- } \\
\text { through option rate for } 5- \\
\text { year Business Energy Tax } \\
\text { Credits effective October } \\
1,2003 \text {, is } 25.5 \% \text {. The } \\
\text { pass-through option rate }\end{array}$ \\
\hline
\end{tabular}




\begin{tabular}{|c|c|c|c|c|c|}
\hline State & Program Name & Eligible Recipients & $\begin{array}{l}\text { Incentive } \\
\text { Amount }\end{array}$ & $\begin{array}{l}\text { Third-party Owner } \\
\text { Eligible }\end{array}$ & $\begin{array}{c}\text { Non-profit/Government } \\
\text { Eligible }\end{array}$ \\
\hline & & & & & $\begin{array}{l}\text { for 1-year Business Energy } \\
\text { Tax Credits (those with } \\
\text { eligible costs of } \$ 20,000 \text { or } \\
\text { less) effective October } 1 \text {, } \\
2003 \text {, is } 30.5 \% \text {. }\end{array}$ \\
\hline $\begin{array}{l}\text { Puerto } \\
\text { Rico }\end{array}$ & $\begin{array}{l}\text { Puerto Rico - } \\
\text { Solar Tax } \\
\text { Credit } \\
\text { (Corporate) }\end{array}$ & $\begin{array}{l}\text { Any Puerto Rican taxpayer who has } \\
\text { acquired, assembled, and installed } \\
\text { eligible solar electric equipment. }\end{array}$ & $\begin{array}{l}75 \% \text { during } F Y \\
2007-2008 \text { and } \\
\text { FY 2008-2009; } \\
50 \% \text { during FY } \\
2009-2010 \text { and } \\
\text { FY 2010-2011; } \\
25 \% \text { starting FY } \\
2011-2012\end{array}$ & Not specified & $\begin{array}{l}\text { Potentially; the tax credit } \\
\text { may be transferred, sold, } \\
\text { or otherwise given to "any } \\
\text { other person." }\end{array}$ \\
\hline $\begin{array}{l}\text { Rhode } \\
\text { Island }\end{array}$ & $\begin{array}{l}\text { Residential } \\
\text { Renewable } \\
\text { Energy Tax } \\
\text { Credit } \\
\text { (Corporate) }\end{array}$ & $\begin{array}{l}\text { Taxpayer who (1) owns, rents, or is } \\
\text { the contract buyer of the dwelling(s) } \\
\text { served by the system; the dwelling } \\
\text { or dwellings must be in the main or } \\
\text { secondary residence of the person } \\
\text { who applies for the tax credit or of a } \\
\text { tenant; (2) owns or is the contract } \\
\text { buyer of the system and pays all or } \\
\text { part of the cost of the system; or (3) } \\
\text { is the contractor that owns the } \\
\text { dwelling for speculative sale in } \\
\text { which the system is installed. }\end{array}$ & $25 \%$ & $\begin{array}{l}\text { Yes. Credit is available to } \\
\text { taxpayers who are the } \\
\text { contract buyers of eligible } \\
\text { systems and pay all or part } \\
\text { of the cost of the system. }\end{array}$ & No \\
\hline $\begin{array}{l}\text { South } \\
\text { Carolina }\end{array}$ & $\begin{array}{l}\text { Solar Energy } \\
\text { and Small } \\
\text { Hydropower } \\
\text { Tax Credit } \\
\text { (Corporate) }\end{array}$ & $\begin{array}{l}\text { Taxpayers who purchase and install } \\
\text { an eligible system in or on a facility } \\
\text { owned by the taxpayer. }\end{array}$ & $\begin{array}{l}25 \% \text { for } 2010 \\
\text { was } 30 \% \text { in } \\
2009\end{array}$ & No & No \\
\hline Utah & $\begin{array}{l}\text { Renewable } \\
\text { Energy } \\
\text { Systems Tax } \\
\text { Credit } \\
\text { (Corporate) }\end{array}$ & $\begin{array}{l}\text { Any company that owns a qualified } \\
\text { system. }\end{array}$ & $\begin{array}{l}\text { Residential: } \\
25 \% \\
\text { Commercial: } \\
10 \%\end{array}$ & No & No \\
\hline
\end{tabular}




\begin{tabular}{|c|c|c|c|c|c|}
\hline State & Program Name & Eligible Recipients & $\begin{array}{l}\text { Incentive } \\
\text { Amount }\end{array}$ & $\begin{array}{c}\text { Third-party Owner } \\
\text { Eligible }\end{array}$ & $\begin{array}{c}\text { Non-profit/Government } \\
\text { Eligible }\end{array}$ \\
\hline Vermont & $\begin{array}{l}\text { Business Tax } \\
\text { Credit for Solar } \\
\text { (Corporate) }\end{array}$ & $\begin{array}{l}\text { Corporations that pay corporate } \\
\text { income tax in Vermont that do not } \\
\text { receive grants/funding from CEDF. }\end{array}$ & $\begin{array}{l}30 \% \text { of } \\
\text { expenditures for } \\
\text { systems placed } \\
\text { into service on } \\
\text { or before } \\
\text { December } 31 \text {, } \\
2010\end{array}$ & Not specified & No \\
\hline
\end{tabular}

Source: DSIRE. http://www.dsireusa.orgl. Accessed September 2010.

Note: The information provided in this table presents an overview of state incentives, but it should not be used as the only source of information when making purchasing decisions, investment decisions, tax decisions, or other binding agreements. For more information about individual programs listed above, visit the DSIRE Web site at http://www.dsireusa.org/. 
Table B-5. U.S. Department of Energy Brightfields Program Grants ${ }^{a}$

\begin{tabular}{|c|c|c|c|c|}
\hline $\begin{array}{l}\text { Award } \\
\text { Year }\end{array}$ & $\begin{array}{l}\text { Award } \\
\text { Amount }\end{array}$ & Project & Project Description & Project Status \\
\hline \multirow[t]{3}{*}{2000} & $\$ 30,000$ & $\begin{array}{l}\text { Brockton, MA: } \\
\text { Brownfields to } \\
\text { Brightfields Project }\end{array}$ & $\begin{array}{l}\text { "This project involved attracting a PV system manufacturer to a Brockton } \\
\text { Brownfield and building a solar array on a second site. Anticipation: This } \\
\text { array will bring into productive use up to } 27 \text { acres of idle property and } \\
\text { the array could also generate up to } 6 \mathrm{MW} \text { of electricity. To create } \\
\text { sufficient local demand to attract the manufacturer, other potential sites } \\
\text { for photovoltaic applications will be surveyed." }\end{array}$ & $\begin{array}{l}425 \mathrm{~kW} \text { facility } \\
\text { commercially operational } \\
\text { since September } 27 \\
2006 \text {. Expanded by } 35 \\
\mathrm{~kW} \text { to } 460 \mathrm{~kW} \text { in July } \\
2007 ; \text { grid-connected } \\
\text { selling } 100 \% \text { of output } \\
\text { into New England Power } \\
\text { Pool }\end{array}$ \\
\hline & $\$ 50,000$ & $\begin{array}{l}\text { Atlantic City, NJ: } \\
\text { Cityscape Solar- } \\
\text { Powered Bed and } \\
\text { Breakfast on an } \\
\text { Urban Brownfield. }\end{array}$ & $\begin{array}{l}\text { "Involves the construction of a solar-powered bed and breakfast on an } \\
\text { urban brownfield site in Atlantic City, New Jersey, as part of an overall } \\
\text { neighborhood redevelopment plan with a sustainability theme. The } \\
\text { project will showcase the use of PV in supplying renewable energy and } \\
\text { also contain sustainable features such as recycled building materials } \\
\text { and Energy Star appliances and will be located in the "Cityscape } \\
\text { Neighborhood," an area designed to promote renewable energy, } \\
\text { sustainable building materials, and concepts of New Urbanism." }\end{array}$ & Project canceled \\
\hline & $\$ 50,000$ & $\begin{array}{l}\text { Hanford, WA: } \\
\text { Brightfield Project }\end{array}$ & $\begin{array}{l}\text { "This project will ultimately be the largest PV installation of its kind and } \\
\text { will bring the Brightfield concept to one of the worst Super Fund sites in } \\
\text { the nation. The funding provided will cover a portion of the pilot phase of } \\
\text { the project, involving } 40 \mathrm{~kW} \text {. Later phases will use a wind/solar green } \\
\text { energy blending strategy to finance development up to } 1 \mathrm{MW} \text { or larger. } \\
\text { This solar array will act as a nucleation site around which Energy } \\
\text { Northwest intends to grow a renewable energy industrial park." }\end{array}$ & $\begin{array}{l}38.7 \text { kW system installed } \\
\text { in May } 2002\end{array}$ \\
\hline 2004 & $\$ 65,400$ & $\begin{array}{l}\text { Cedar Rapids, IA: } \\
\text { Bohemian } \\
\text { Commercial Historic } \\
\text { District Solar } \\
\text { Development } \\
\text { Program }\end{array}$ & $\begin{array}{l}\text { "The lowa Department of Natural Resources (IDNR) will partner with the } \\
\text { City of Cedar Rapids, the lowa Renewable Energy Association, Alliant } \\
\text { Energy, and Thorland Company to install a 7,200-watt solar array in } \\
\text { Cedar Rapids on a multiuse converted former warehouse building in a } \\
\text { designated brownfields redevelopment area. The IDNR has established } \\
\text { partnerships with the City of Cedar Rapids, Alliant Energy, the lowa } \\
\text { Renewable Energy Association, and the building owner to increase the } \\
\text { economic and environmental viability of a redeveloped brownfield area } \\
\text { and expand the value and viability of solar projects." }\end{array}$ & $7.2 \mathrm{~kW}$ installed \\
\hline
\end{tabular}


$\$ 59,400$

Brockton, MA: Solar Energy Park:

Deploying a Solar Array on a Brownfield

$\$ 125,000$ Raleigh, NC: Brightfield Technology Demonstration at NCSU
"The City of Brockton will build New England's largest solar array at a remediated 27 -acre brownfield site in fall 2004 . The $500-k W$ solar PV array—or 'Brightfield' - will be installed in an urban park setting with interpretive displays. The Brightfield could include as many as 6,720 solar panels connected in strings that span the site. The Brightfield will grow incrementally to $1 \mathrm{MW}$ with expansions financed through positive annual cash flow generated by the sale of RECs and electricity."

"Carolina Green Energy, LLC proposes to partner with the North

Carolina Solar Center to design and install a $30-\mathrm{kW}$ grid-tied PV system.

As part of its continued efforts to bolster support for renewable energy, the Solar Center will incorporate the "Brownfield to Brightfield" project at Lot 86 into its ongoing education and outreach programs."
425-kW facility commercially operational since September 27, 2006. Expanded by 35 $\mathrm{kW}$ to $460 \mathrm{~kW}$ in July 2007; grid-connected selling $100 \%$ of output into New England Power Pool

75.6-kW PV-generation project operational since October 2007

Source: U.S. DOE State Energy Program. http://www.hud.gov/offices/cpd/affordablehousing/training/web/energy/programs/doe.cfm. Accessed September 2010.

According to EPA, the term brightfields refers to "the conversion of contaminated sites into usable land by bringing pollution-free solar energy and high-tech solar manufacturing jobs to these sites, including the placement of PV arrays that can reduce cleanup costs, building integrated solar energy systems as part of redevelopment, and solar manufacturing plants on brownfields." For more information, see http://epa.gov/ and brownfields/partners/brightfd.htm. 
Table B-6. State Policy and Incentive Comparisons: Massachusetts, North Carolina, and Colorado

\section{MASSACHUSETTS}

Incentive

New Generation Energy - Community

Solar Lending Program

Massachusetts DOER - Solar

Renewable Energy Credits (SRECs)

Mass Energy Consumers Alliance -

Renewable Energy Certificate Incentive

Renewable Energy Property Tax

Exemption

CEC - Commonwealth Solar II Rebates

CEC - Commonwealth Solar Stimulus

Policy

Massachusetts - Net Metering

Renewable Energy Trust Fund

RPS

\begin{tabular}{ll} 
Specifics & Sector \\
\hline$\$ 5,000-\$ 100,000$ & Private \\
$\$ 300-\$ 600$ (per MWh) & Both \\
& Both \\
& Private \\
$100 \%$ exemption for 20 years & Both \\
$\begin{array}{l}\$ 5,500 \text { (per host customer), up to } \\
\$ 250,000 \text { per parent company } \\
\$ 162,500 \text { per project (up to } \$ 1 \text { million } \\
\text { for any host customer entity or parent } \\
\text { company/organization) } \\
\text { Specifics }\end{array}$ & Both \\
\hline & \\
$\begin{array}{l}\text { Public benefit fund } \\
\text { In-state PV: mandated target of } 400 \\
\text { MW }\end{array}$ & Sector \\
\hline
\end{tabular}

\section{NORTH CAROLINA}

Incentive

Renewable Energy Tax Credit (Corporate)

Local Option - Revolving Loan Program for Renewable Energy and Energy

Efficiency

Local Option - Clean Energy Financing

Renewable Energy Tax Credit

(Personal)

NC GreenPower Production Incentive

Progress Energy Carolinas - SunSense Commercial PV Incentive Program

TVA - Generation Partners Program

Property Tax Abatement for Solar Electric Systems

North Carolina Green Business Fund

Energy Improvement Loan Program (EILP)

\begin{tabular}{ll} 
Specifics & Sector \\
\hline $35 \%$ or $\$ 2.5$ million per installation & Private
\end{tabular}

Interest rate can be no more than $8 \% \quad$ Private

Debt repaid via property assessment Private

$35 \%$ or $\$ 2.5$ million per installation Private

Payments contingent on program Both success

$\$ 0.18 / \mathrm{kWh}$ for 20 years Both

$\$ 1,000$ plus $\$ 0.12 / \mathrm{kWh}$ above the retail Private rate for solar and $\$ 0.03 / \mathrm{kWh}$ above the retail rate for all other eligible renewables

$80 \%$ of appraised value Both

Grant varies Both

State Loan Program $\$ 500,000 \quad$ Both

maximum 


\section{Policy}

North Carolina - Net Metering

Renewable Energy and Energy

Efficiency Portfolio Standard

\section{COLORADO}

Incentive

Boulder County - ClimateSmart Loan

Program

Local Option - Improvement Districts for

Energy Efficiency and Renewable

Energy Improvements

Renewable Energy Property Tax

Assessment

Boulder - Solar Sales and Use Tax

Rebate

Local Option - Sales and Use Tax

Exemption for Renewable Energy

Systems

Sales and Use Tax Exemption for

Renewable Energy Equipment

New Energy Economic Development Grant Program

Xcel Energy - Solar*Rewards Program

Policy

Colorado - Net Metering

Mandatory Green Power Option for

Large Municipal Utilities

Boulder - Climate Action Plan Fund

Renewable Energy Standard

Solar, Wind, and Energy-Efficiency

Access Laws

Source: U.S. DOE State Energy Program. http://www.sseb.org/files/renewable-portfolio-standards.pdf. Accessed September 2010.
Specifics

Sector

Solar: $0.2 \%$ by 2018

\begin{tabular}{ll} 
Specifics & Sector \\
\hline Commercial: $\$ 3,000-\$ 210,000$ & Private \\
Debt repaid via property assessment & Both \\
Varies & Private \\
$\begin{array}{l}15 \% \text { refund on sales and use tax for the } \\
\text { solar installation }\end{array}$ & Private \\
Varies & Private \\
$\begin{array}{l}\text { 100\% } \\
\text { Competitive grant, Recovery Act funded }\end{array}$ & Private \\
$\begin{array}{l}\text { \$2/DC-Watt with a maximum rebate of } \\
\$ 200,000 ; \text { REC payments will step } \\
\text { down over time as certain MW levels } \\
\text { are reached for each system } \\
\text { classification. }\end{array}$ & Private \\
Specifics & \\
\hline $\begin{array}{l}\text { Allows retail customers the choice of } \\
\text { supporting emerging renewable } \\
\text { technologies } \\
\text { Public benefits fund }\end{array}$ & Both \\
& Private \\
&
\end{tabular}

Solar-electric (IOUs only): $4 \%$ of annual requirement $(0.8 \%$ of sales in 2020$)$; half of solar-electric requirement must be located on-site at customers' facilities 
Table B-7. Key Policy Comparison for Subject States

\begin{tabular}{|c|c|c|c|}
\hline RPS & Massachusetts & North Carolina & Colorado \\
\hline Policy In Place & Yes & Yes & Yes \\
\hline Effective Date & $4 / 1 / 02$ & $2 / 29 / 08$ & $12 / 1 / 04$ \\
\hline Targets & $\begin{array}{l}15 \% \text { by } 2020 \text { and an } \\
\text { additional } 1 \% \text { each year } \\
\text { thereafter; in-state PV } \\
\text { mandated target of } 400 \\
\text { MW }\end{array}$ & $\begin{array}{l}12.5 \% \text { of } 2020 \text { retail } \\
\text { electricity sales by } 2021 \\
\text { with } 0.2 \% \text { from solar }\end{array}$ & $\begin{array}{l}20 \% \text { by } 2020 \text {; solar- } \\
\text { electric: } 4 \% \text { of annual } \\
\text { requirement }\end{array}$ \\
\hline PBF & Massachusetts & North Carolina & Colorado \\
\hline Policy In Place & Yes & No & City of Boulder only \\
\hline Effective Date & $3 / 1 / 98$ & $\mathrm{~N} / \mathrm{A}$ & $4 / 1 / 07$ \\
\hline \multirow[t]{3}{*}{ Charge } & $\begin{array}{l}\$ 0.0005 \text { per } \mathrm{kWh}(\$ 0.5 \\
\text { million/kWh) in } 2003 \text { and } \\
\text { in each following year }\end{array}$ & $\mathrm{N} / \mathrm{A}$ & $\begin{array}{l}\text { Maximum tax rates for } \\
\text { electricity customers: } \\
\text { Residential: } \\
\$ 0.0049 / \mathrm{kWh}\end{array}$ \\
\hline & & & $\begin{array}{l}\text { Commercial: } \\
\$ 0.0009 / \mathrm{kWh}\end{array}$ \\
\hline & & & Industrial: $\$ 0.0003 / \mathrm{kWh}$ \\
\hline NET METERING & Massachusetts & North Carolina & Colorado \\
\hline Policy In Place & Yes & Yes & Yes \\
\hline Effective Date & 1982 & $10 / 20 / 05$ & $7 / 2 / 06$ \\
\hline System Capacity & $\begin{array}{l}2 \mathrm{MW} \text { for "Class III" } \\
\text { systems; } 1 \mathrm{MW} \text { for "Class } \\
\text { II" systems; } 60 \mathrm{~kW} \text { for } \\
\text { "Class I" systems }\end{array}$ & $1 \mathrm{MW}$ & $\begin{array}{l}120 \% \text { of the customer's } \\
\text { average annual } \\
\text { consumption }\end{array}$ \\
\hline REC Ownership & Customer owns RECs & $\begin{array}{l}\text { Utility owns RECs } \\
\text { (unless customer } \\
\text { chooses to net meter } \\
\text { under an unfavorable } \\
\text { demand tariff) }\end{array}$ & $\begin{array}{l}\text { Customer owns RECs } \\
\text { (must be relinquished to } \\
\text { utility for } 20 \text { years in } \\
\text { exchange for incentives) }\end{array}$ \\
\hline \multirow{2}{*}{$\begin{array}{l}\text { TAX INCENTIVES } \\
\text { APPLICABLE TO PV } \\
\text { Incentives }\end{array}$} & Massachusetts & North Carolina & Colorado \\
\hline & $\begin{array}{l}\text { Property - } 100 \% \\
\text { exemption for } 20 \text { years }\end{array}$ & $\begin{array}{l}\text { Corporate }-35 \% \\
\text { Property }-85 \% \text { of } \\
\text { appraised value }\end{array}$ & $\begin{array}{l}\text { Property - Amount } \\
\text { varies depending on rate } \\
\text { set annually by the } \\
\text { Division of Property } \\
\text { Taxation }\end{array}$ \\
\hline Effective Date & 1984 & $\begin{array}{l}\text { Corporate } 1 / 1 / 09 \\
\text { Property } 7 / 1 / 08\end{array}$ & 2001 \\
\hline
\end{tabular}

Source: DSIRE. http://www.dsireusa.org/. Accessed September 2010. 


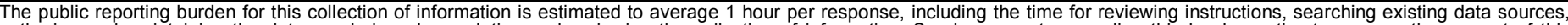

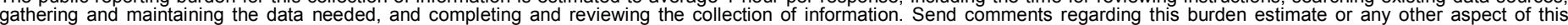

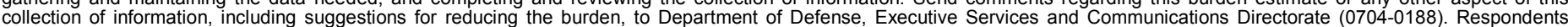

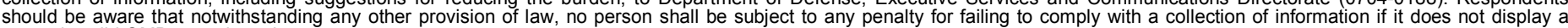

surrently alid OMB

PLEASE DO NOT RETURN YOUR FORM TO THE ABOVE ORGANIZATION.

\begin{tabular}{l|l|l} 
1. REPORT DATE (DD-MM-YYYY) & 2. REPORT TYPE & 3. DATES COVERED (FrOm - TO)
\end{tabular}

March 2011

Technical Report

4. TITLE AND SUBTITLE

Feasibility Study of Economics and Performance of Solar

Photovoltaics in the Commonwealth of Puerto Rico. A Study

Prepared in Partnership with the Environmental Protection Agency

for the RE-Powering America's Land Initiative: Siting Renewable

Energy on Potentially Contaminated Land and Mine Sites

5a. CONTRACT NUMBER

DE-AC36-08GO28308

5b. GRANT NUMBER

5c. PROGRAM ELEMENT NUMBER

6. AUTHOR(S)

James Salasovich and Gail Mosey

5d. PROJECT NUMBER

NREL/TP-6A20-49237

5e. TASK NUMBER

WFD6.1000

5f. WORK UNIT NUMBER
7. PERFORMING ORGANIZATION NAME(S) AND ADDRESS(ES)

National Renewable Energy Laboratory

1617 Cole Blvd.

Golden, CO 80401-3393
8. PERFORMING ORGANIZATION REPORT NUMBER

NREL/TP-6A20-49237

9. SPONSORING/MONITORING AGENCY NAME(S) AND ADDRESS(ES)

10. SPONSOR/MONITOR'S ACRONYM(S)

NREL

11. SPONSORING/MONITORING AGENCY REPORT NUMBER

12. DISTRIBUTION AVAILABILITY STATEMENT

National Technical Information Service

U.S. Department of Commerce

5285 Port Royal Road

Springfield, VA 22161

13. SUPPLEMENTARY NOTES

14. ABSTRACT (Maximum 200 Words)

This report presents the results of an assessment of the technical and economic feasibility of deploying a

photovoltaics (PV) system on brownfield sites in the Commonwealth of Puerto Rico. All of the assessed sites are landfills. The sites were assessed for possible PV installations. The cost, performance, and site impacts of different PV options were estimated. The economics of the potential systems were analyzed using an electric rate of $\$ 0.119 / \mathrm{kWh}$ and incentives offered by Puerto Rico and by the serving utility, PREPA. According to the site production calculations, the most cost-effective system in terms of return on investment is the thin-film fixed-tilt technology. The report recommends financing options that could assist in the implementation of such a system.

15. SUBJECT TERMS

feasibility study; solar photovoltaics; PV system; ground-mounted PV; Puerto Rico; brownfields; cost; performance; site impacts; financial incentives; financing options

\begin{tabular}{|c|c|c|c|c|}
\hline \multicolumn{3}{|c|}{ 16. SECURITY CLASSIFICATION OF: } & \multirow{2}{*}{$\begin{array}{l}\text { 17. LIMITATION } \\
\text { OF ABSTRACT } \\
\text { UL }\end{array}$} & \multirow{2}{*}{$\begin{array}{l}\text { 18. NUMBER } \\
\text { OF PAGES }\end{array}$} \\
\hline $\begin{array}{l}\text { a. REPORT } \\
\text { Unclassified }\end{array}$ & $\begin{array}{l}\text { b. ABSTRACT } \\
\text { Unclassified }\end{array}$ & $\begin{array}{l}\text { c. THIS PAGE } \\
\text { Unclassified }\end{array}$ & & \\
\hline
\end{tabular}

19a. NAME OF RESPONSIBLE PERSON

19b. TELEPHONE NUMBER (Include area code) 